\title{
Uneven development and peri-urbanization in South Africa: Exploring landscape change in Polokwane, South Africa
}

Jennifer L. Smith

Follow this and additional works at: https://researchrepository.wvu.edu/etd

\section{Recommended Citation}

Smith, Jennifer L., "Uneven development and peri-urbanization in South Africa: Exploring landscape change in Polokwane, South Africa" (2015). Graduate Theses, Dissertations, and Problem Reports. 6671. https://researchrepository.wvu.edu/etd/6671

This Dissertation is protected by copyright and/or related rights. It has been brought to you by the The Research Repository @ WVU with permission from the rights-holder(s). You are free to use this Dissertation in any way that is permitted by the copyright and related rights legislation that applies to your use. For other uses you must obtain permission from the rights-holder(s) directly, unless additional rights are indicated by a Creative Commons license in the record and/ or on the work itself. This Dissertation has been accepted for inclusion in WVU Graduate Theses, Dissertations, and Problem Reports collection by an authorized administrator of The Research Repository @ WVU.

For more information, please contact researchrepository@mail.wvu.edu. 


\title{
UneVEn DeVElopment AND PeRI-URbanization In SOUTH Africa: Exploring LANDSCAPE Change in PolokWANe, SOUTH AFRICA
}

\author{
Jennifer L. Smith \\ Dissertation submitted \\ to the Eberly College of Arts and Sciences \\ at West Virginia University \\ in partial fulfillment of the requirements for the degree of \\ Doctor of Philosophy in \\ Geography \\ Dr. Brent McCusker, Ph.D., Chair \\ Dr. Jeremia Njeru, Ph.D. \\ Dr. Phil O'Keefe, Ph.D. \\ Dr. Timothy Warner, Ph.D. \\ Dr. Bradley Wilson, Ph.D.
}

Department of Geology and Geography

Morgantown, West Virginia

2015

Keywords: South Africa, uneven development, peri-urbanization, post-apartheid Copyright 2015 Jennifer L. Smith 


\section{ABSTRACT \\ Uneven Development and Peri-urbanization in South Africa: Landscape change in Polokwane, South Africa}

\section{Jennifer L. Smith}

Changes in local landscapes of South Africa are tied to changing social and economic structures of the post-apartheid era. Though there have been significant shifts in land and labor laws, as well as economic policies, between the apartheid era and current times, significant inequalities between communities remain a defining characteristic of the postapartheid landscape. This research contends that through a combination of social processes occurring between the local, national, and global scales, local landscape is produced unevenly as a manifestation of the coproduction of space. Using a structuralist approach, the research examines local change through the theoretical lenses of uneven development, co-production, and deproletarianization. These approaches each seek to explain the processes surrounding peri-urbanization trends near the research site of Polokwane, South Africa. Using a mixed methods approach for data collection connects the theoretical implications to the lived realities of individuals in South Africa. The mixed methods include quantitative surveys, qualitative and semi-structured interviews, focus groups, and geospatial technologies, through which I gained a deeper understanding of the social processes influencing local livelihoods and land use patterns. The results of this research demonstrate that new areas of peri-urban growth represent significantly lower living standards than the suburban growth near the city. While periurban areas have grown the most between 1990 and 2009, some of this growth is represented by informal settlements where access to urban infrastructure is scarce and poorly developed. Deproletarianization contributes to uneven geographical development by limiting access to the wage labor market and forcing people to live close to the city in order to gain access to this resource. Furthermore, this process interacts with local and national level macro-economic policies aimed toward capitalist growth rather than community development to create great unevenness both within and between peri-urban areas. In addition, local governance and past-apartheid policies also influence the scope and direction of peri-urban growth and livelihood possibilities for individuals and households living in the peri-urban interface. This research concludes that while Polokwane, South Africa might be in a post-apartheid era of governance it is certainly not in a post-poverty era. 


\section{ACKNOWLEDGEMENTS}

\section{This research was funded by a National Science Foundation DDRI Grant (\#1128868) to conduct fieldwork in South Africa in 2012.}

\section{This research was also supported by a GeoEye (Digital Globe) Foundation Imagery Grant.}

This dissertation research is very much a product of many people in many places. To each and every person involved in this project - thank you and I appreciate all of your help, support, and grace along the way.

First I'd like to thank my husband Corey, for tirelessly supporting me in this endeavor, giving me his strength when I had none left, and making me laugh a whole lot along the way. I am eternally grateful. He does deserve an honorary master's degree at the least.

I'd also like to thank my advisor, Brent McCusker, who has been the best mentor any professional could ever hope to encounter. Thanks for always pushing me to be better than I am, and for supporting me in all paths of my life.

Many thanks also to my dissertation committee Tim Warner, Bradley Wilson, Jeremia Njeru, and Phil O'Keefe for their dedicated support during the foundational reading, research, and writing processes. I needed each of you on this committee for very different reasons and you each brought balance to the force. Thank you for your time, your counsel, and your help in this and other adventures. I'd also like to thank my informal committee members in the department who supported and mentored me in professional development: Cynthia Gorman, Maria Perez, Karen Culcasi, and Ann Oberhauser. I couldn't have done this without you either!

To my research team in South Africa: Johnny Monyebodu, Modjadji Alexia Mothiba, Dipitsi Augustine Mothiba, Lousia Mothiba, and Lesedi Kanyane - thank you for your tireless efforts, friendship, and hard work on this project. It would not have been possible without you! Also, many thanks to the University of Limpopo for their hospitality and Dr. Parvin Shaker, Dr. Marubini Ramudzuli, and Dr. Kingsley Ayisi for their support of both my research and my time on UL's campus.

Additional thanks to the Department of Geology and Geography for funding me through the dissertation process, and for helping with research, and travel funding. Also, many thanks to the Eberly College of Arts and Sciences for travel funding.

Finally, my family and friends, I wouldn't have been able to do any of this without you and your support. To my family, who spent time with the little man, giving me time and space to write, and to my friends: Jessi, Ashley, Beth, Nicki, Angie, Ally, Josh, the Jessicas, Kevin, Andrew, 
Evan, and so many, many more there are no words to express my gratitude for your patience, understanding and encouragement through this process. I love you all!

And Praise to strength from above, which I will never fully understand, for setting a fire in this heart. 


\section{TABLE OF CONTENTS}

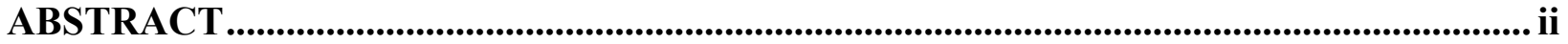

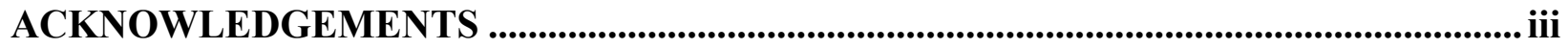

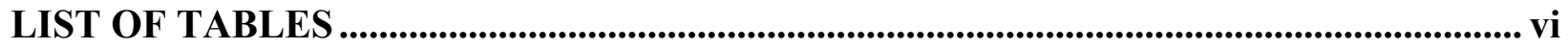

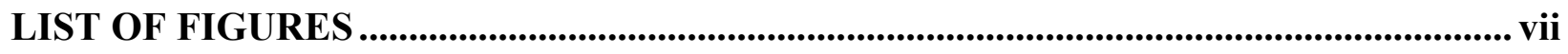

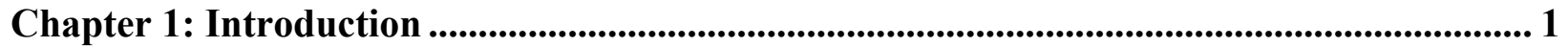

Chapter 2: Deproletarianization in the Peri-Urban Interface: transforming labor relations

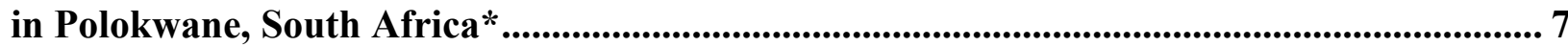

Chapter 3: Post-Apartheid Uneven Development of Polokwane, South Africa................... 38

Chapter 4: The Co-Production of Peri-Urban Space .................................................... 67

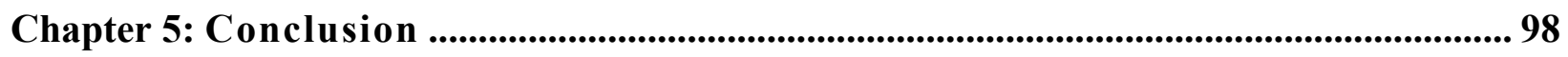

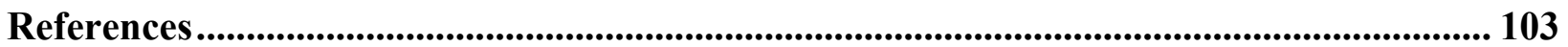




\section{LIST OF TABLES}

Table 2-1: Unemployment figures. Data from Statistics SA South African Census 2011......... 19

Table 2-2: Household Survey Expense and Income Data 2012 ........................................... 31

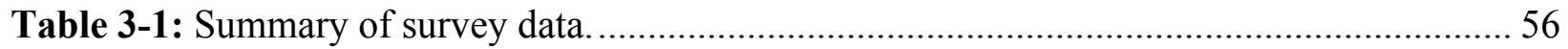

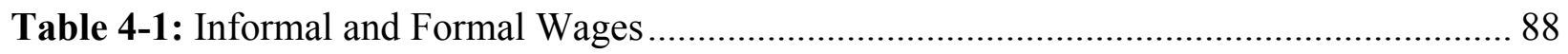




\section{LIST OF FIGURES}

Figure 2-1: Statistics South Africa 2011 Census Unemployment Data ................................................ 21

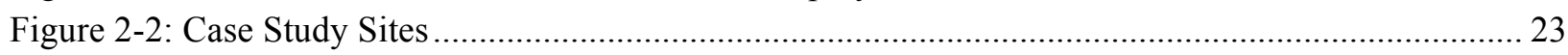

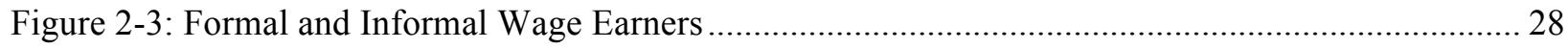

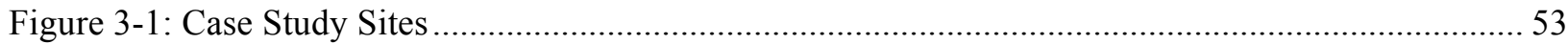

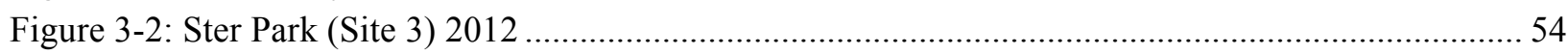

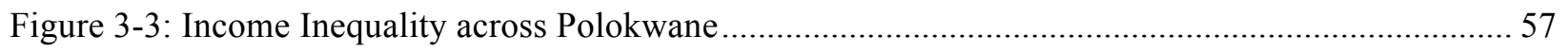

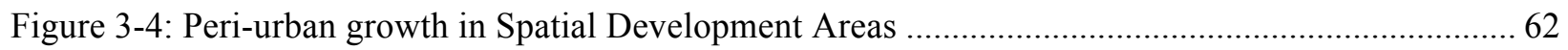

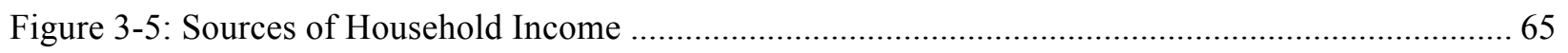

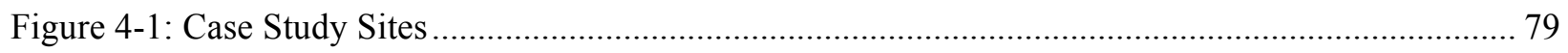

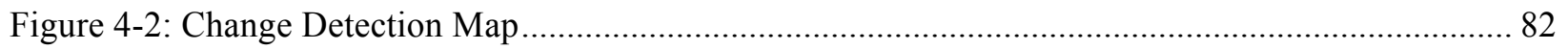

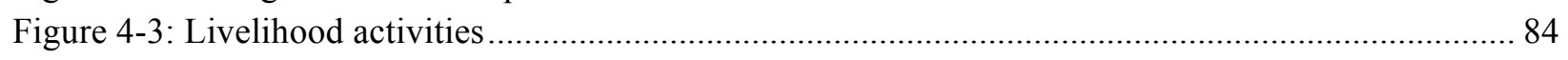

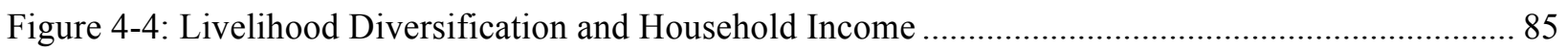

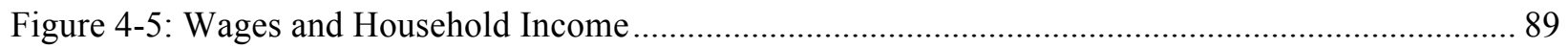




\section{CHAPTER1: INTRODUCTION}

In 2014 South Africans throughout the world celebrated twenty years of democracy. As Nelson Mandela so eloquently stated, "For to be free is not merely to cast off one's chains, but to live in a way that respects and enhances the freedom of others" (Mandela 1994: 624). Considered an economic beacon in Africa, South Africa's progress is often measured by a growing global economic presence. Black empowerment programs are moving South Africa towards a more equal society; however, progress has not been equally distributed among the population. Though apartheid has ended, its legacy remains a constant reminder of past injustices - largely because those injustices have not yet been remedied. The inequalities engrained in the apartheid system, specifically the spatial planning outcomes, have not been undone and no policy was ever created

to systematically "undo" the effects of apartheid spatial planning (Christopher 2001). It is important to understand the mechanisms creating inequality to tackle the challenges still facing South Africa.

This research postulates that South Africa is subject to continued processes of uneven development, whereby the capitalist mode of production produces space to facilitate the accumulation of capital. Unlike the apartheid era, when capital fixation in the landscape was based upon race and class, the latter now dominates the production of space in the country. This materializes in the creation of peri-urban space, which has distinct class characteristics as well as continued and significant racial dimensions. Urban development in South Africa remains highly uneven with households in some communities being the recipients of economic wealth, technological advancement and high standards of living. Meanwhile, other households and neighborhoods experience the opposite: under-development, high poverty rates, poor standards 
of living, and limited quality of life. South Africa is subject to the processes of uneven development at global, national, and local scales through the interaction of a variety of forces operating at each level (e.g.: global economic trends, national and local governance, and local levels of development). Therefore, the objectives of this research are to track and explain the physical and social changes occurring in the peri-urban landscape of Polokwane, South Africa as a result of these processes. Uneven development, political economy of nature, and co-production frameworks help explain the processes contributing to change. Extreme differentiation in Polokwane's urban growth is tied to (1) deproletarianization, (2) uneven development, and (3) the coproduction of land use and livelihoods in the peri-urban interface.

Peri-urbanization, a process through which both urban and rural characteristics shape landscape production, occurs as a temporary stabilization and manifestation of uneven development. Such processes manifest themselves through the coproduction of land use and livelihoods. The moments affecting the coproduction of space and continued uneven development have resulted from the interplay between historical land uses, political segregation, political power, livelihood activities, economic structures, migration, and global economic systems. Furthermore, they all play a role in the production of peri-urban space in South Africa. In this case study, the dialectic expands beyond capitalist processes of accumulation and postapartheid state spatial planning to include the co-production of land uses and livelihoods. Using this approach avoids homogenizing narratives and economic deterministic analysis of landscape production. This research focuses on the inter-connectivity of the many aspects of periurbanization, in an attempt to disentangle the complex processes producing negative lived experiences in Limpopo, South Africa. 
Field data collection occurred between January and July of 2012 in Polokwane, South Africa. Polokwane is a major city, centrally located in Limpopo, the northeastern most province. The city connects via road networks to neighboring countries, Botswana and Zimbabwe, and is only three hours northeast, by car or bus, of the Johannesburg-Pretoria metropolitan area. The research used three strategic study sites near the city. Each site was of varying proximity to downtown Polokwane and based upon recent landscape changes and varying levels of economic prosperity.

The first article, Chapter 2, of this dissertation focuses on deproletarianization as a change in labor relations in Polokwane. During these semi-structured interviews, I observed that participants frequently cited access to labor markets as one of the most influential reasons for relocating or moving to the peri-urban interface. The resulting discussions focused on work, jobs (or lack thereof), labor rights and challenges to those rights. These themes illustrated a need to critically explore the changing labor relations in Polokwane, because changing labor relations are a significant contributor to peri-urban growth.

Proponents of the deproletarianization thesis argue that wage labor is no longer a commodity in Polokwane. This means that laborers are unable to sell their labor, and labor is decommodified. It also implies that individuals must work multiple jobs, find sporadic or piecemeal employment, or return to other livelihood strategies to make ends meet. Historically, labor in South Africa proletarianized when individuals were forced off the land through primitive accumulation to work in the diamond and gold mines, during the early 1900s (see Bundy 1988). The bantustans were a hub for cheap, African labor and were located on some of the most marginalized land in the nation (see Legassick and Wolpe 1976). Among the first steps taken in creating a proletarianized but disciplined labor force were the formation of the bantustans. 
Class based processes replaced many of the policies that formed the bantustans. Throughout the economic liberalization trends of the late 1990s and early 2000s, both globally and in South Africa, capitalists were able to locate fixed capital just about anywhere in the world. Yet they still require a cheap labor force and deproletarianization is capital's way of disciplining labor in South Africa where labor unions are historically strong. This keeps wages low, as unemployment soars, and many individuals are under-employed.

The challenges of local labor relations in Polokwane similarly reflect the continued power and presence of the capitalist mode of production in affecting landscape change in South Africa. While deproletarianization is shifting labor relations, Chapter 3 focuses on the other processes of capital expansion that are also taking place as RDP townships and informal settlements, and are replacing apartheid townships and bantustans as labor reserves. RDP townships are areas of government-funded housing development, which reflect the style of former Reconstruction and Development Programme housing. These structures first emerged immediately following the end of apartheid as a way for poorer households and black populations to enter the housing market. The growth of RDP (Reconstruction and Development Programme) townships and informal settlements in peri-urban areas, just outside of the city of Polokwane are continuing the pattern and legacy of uneven development in South Africa. Rather than concentrating poverty in the rural areas, poverty moved to peri-urban spaces where livelihoods are highly monetized and more dependent on wage labor than their rural counterparts. Urban growth is highly unequal, with populations in the suburbs making twentytwo times the amount of households in the peri-urban interface. Chapter 3 also explains the failures of both national and local policy to address the many concerns of local citizens especially in terms of land reform, land use policy, and access to services. 
Chapter 4 explores changing land use and livelihood dynamics occurring in the growing peri-urban areas of Polokwane. The penultimate chapter focuses on the manner in which land use and livelihoods are co-produced by physical materialities and discursive formations as individuals negotiate the challenges of everyday life in the peri-urban interface. Through these negotiations, the fusion and interaction of social processes operating across scale produce periurban space. In more detailed terms, social processes (including labor relations, governance, gender, access to physical and social networks) produce landscape change (land cover) and are negotiated at the local, regional, national, and global scale. Between 1990 and 2009, peri-urban areas grew by over 10,000 hectares (primarily for housing and residential purposes). Peri-urban growth outside of Polokwane has been greatest in Ward 8, along the Nelson Mandela Boulevard in a Spatial Development Area (government directed development zone).

Scholars have established a detailed record of using remotely sensed images and modern classification techniques to document landscape change, including peri-urban growth. But the change in land cover/land use is not isolated to or caused by specific drivers. Rather, land cover change and livelihoods are co-produced at the local scale through the negotiation of individual lived experiences, which contribute to migration and making ends meet within the peri-urban zone. The co-production framework allows for an inclusive analysis of the many processes, which produce the large disparity in household wealth both within and between peri-urban communities. Specifically in Polokwane, the interplays between accessing the labor market, livelihood diversification, government housing projects, government-directed spatial development areas, and access to formal and informal economies have influenced the coproduction of land use and livelihoods and therefore, peri-urban space. 
While each of these chapters focus on a particular aspect of uneven development processes, they also engage a framework that seeks to explain the production of peri-urban space in Polokwane, South Africa. Rather than isolate a specific cause-and-effect relationship between peri-urban expansion and social structures, this research explores several avenues, or moments, which contribute to the continued physical manifestation of uneven development in the landscape of South Africa. Using an open dialectical approach, this research identifies the contributing components of peri-urban development and some of the negative lived experiences of peri-urban residents.

This body of work seeks to critically examine the production of space through a variety of social processes operating at different scales. By applying the co-production framework to land use and livelihoods analysis in Polokwane, this research highlights both broad and narrow activities contributing to both the positive and negative lived experiences in the peri-urban interface. By understanding these experiences, local leaders and government, at all scales, can begin to more adequately address the challenges faced by South Africans. Similarly, this research contributes to grounding critical social theory in the lived reality of individuals and households by focusing on the temporary stabilizations of a multitude of dialectical processes. 


\title{
Chapter 2: DEPROLETARIANIZATION IN THE PERI-URBAN INTERFACE: TRANSFORMing LABOR RElations in POLOKWANE, SOUTH AFriCA*
}

\begin{abstract}
High unemployment rates and the search for job opportunities are defining characteristics of the modern day South African economy. As apartheid era labor and land controls continue to break down, many households find themselves searching for work in an economy characterized by surplus labor. Examining high unemployment rates through the theoretical lens of deproletarianization provides an explanation of persistent unemployment and poverty more complex and complete than others. Research conducted in Polokwane, South Africa demonstrates increasing peri-urbanization as a physical manifestation of these changing labor relations. ${ }^{1}$ In an era dominated by global capitalism, theoretical engagements help explain household poverty, the failure of South Africa's economy to absorb excess labor, and how persistent unemployment contributes to a reconfiguration of space in South Africa's urban and peri-urban areas. The research team used a combination of qualitative semi-structured interviews and quantitative surveys to gain insight into household livelihoods and individual experiences. The deproletarianization argument applied here asserts that labor has become unfree in South Africa and represents a new form of labor discipline. Through the deproletarianization thesis, the labor market can be better understood to inform future unemployment and poverty research in South Africa.
\end{abstract}

\footnotetext{
${ }^{1}$ This research was funded by a grant from the National Science Foundation (DDRI\# 1128868) and an imagery grant from Digital Globe.

*Published in Human Geography (Volume 7, Number 3, pages 44-59).
} 


\section{Introduction}

Indistinguishable amongst a row of shacks, the meeting room was composed of two rather large pieces of sheet metal. In the middle was a folding table surrounded by ten metal chairs.

"Life is all the same because we are achieving nothing," an old man promptly stated.

The translator replied, "This question actually wants to know if life was better at home or here."

"There's no better place; it's all the same" said the old man.

"It is all the same." A young woman from across the room echoed.

The old man continued, "We moved from our homes to avoid poverty by coming here and being close to factories but there is no difference because we do not get jobs. We tried to run away from poverty at home but we are still poverty-stricken here."

Previously McCusker, O'Keefe, O’Keefe and O'Brien have written in this journal about the potential explanatory power of deproletarianization (McCusker et al. 2013) as a shift in labor relations where labor is no longer a commodity. This paper extends that analysis into peri-urban South Africa, where changing labor relations and high unemployment are characteristic of local labor markets. By examining these changes through a historical materialist approach and deproletarianization, this paper seeks to develop the deproletarianization thesis and apply it to local labor markets. Though South African's have no alternative to wage labor as a key component of household income, their labor has ceased to be a commodity. However, the search for employment continues to lure people into cities. This occurs not only in South Africa, but also throughout the global South (Simon 2008). Around the world, people are leaving their 
rural villages in search of work but to no avail. Instead, migrants tend to find cities flush with people having the same objective. Jobs are scarce and access to housing and services are very limited.

This paper explores changing labor relations in the peri-urban interface of Polokwane, South Africa. The peri-urban interface is a confluence of urban and rural land use and livelihood processes. In peri-urban areas, the breakdown of local labor markets is aggravated by neoliberal economic policy and post-apartheid desegregation trends occurring in South Africa. However, the deproletarianization of local labor has resulted in new forms of labor discipline, which now replace apartheid era labor regulations. Manifest in the peri-urban interface, the intersection of persistent unemployment and a large labor force mean that individuals are no longer able to commodify or recommodify their labor. As labor is decommodified, it becomes "unfree" (Brass 2011a). Based upon descriptive statistics of household livelihoods surveys and individual lived experiences, changing labor relations at the forefront of household production and reproduction are explored.

By examining the point of production and labor regimes, this approach examines labor relations within capitalism and facilitates a deeper understanding of how labor relations contribute to poverty in South African communities. Eighteen years into the democratic era, neoliberal economic policies promising economic growth and wealth redistribution have accentuated unevenness (Marais 2011). Because apartheid socioeconomic structures in South Africa were predicated on racial capitalism and grounded in race-based labor policies, examining continued unemployment, as a labor and class relation should demonstrate whether or not South Africa has moved to post-racial capital.

In this case study example, labor relations are examined through the concept of 
deproletarianization (Brass 2011a). The hypothesis put forth in this paper is that neo-liberal capitalism is leading to a remaking of urban space where an increase in peri-urban settlement is relocating surplus labor from the former bantustans (see Legassick and Wolpe 1976) and townships of South Africa to peri-urban spaces. This high concentration of unemployed and underemployed individuals represents a change in the class structure, where individuals are no longer proletarians, but deproletarians, as their labor is no longer a commodity (Brass 2011b).

To better understand this remaking of urban space, this paper briefly reviews the apartheid city and pre-democratic race based labor relations. A condensed economic history relating to current unemployment rates and a review of peri-urbanization follows. The next section analyzes current wage labor conditions and describes the research study sites in Polokwane, South Africa. The final sections examine the data and empirical analysis, evaluate the findings, and discuss the application of the deproletarianization thesis to unemployment (Brass 1994, 2011a).

\section{The Apartheid City and Labor}

Urban patterns in South Africa have been influenced by European settlement since the 1600s and continue to resemble colonial cities. Racial segregation was an important component of the colonial city as well as the growth and structure of cities in South Africa. The late nineteenth century marked the beginning of the restriction of settlement patterns based upon race (Christopher 2001). Focus on control over black residential spaces was a key element in South African urban planning (Mabin and Smit 1997). Serving a variety of material interests, urban segregation partially began with the emergence of large mining complexes (ibid). Separation continued through industrialization and capitalist development spurred by the mineral revolution 
(Maylam 1995).

Urban segregation passed the legislature in 1923, Natives (Urban Areas) Act, when municipalities were required to plan locations for strictly white housing (Mabin and Smit 1997). Additionally, legislative measures to control the influx of black migrant labor to urban areas solidified under the Native Laws Amendment Act of 1937. This provided for systematic control over African influx to urban areas. Urban growth through African migration was due to the demand of expanding industry (Lemon 1976), but unrest among white residents about the increasing black population contributed to an intense bureaucratic system of influx control for black labor (McCusker et al. forthcoming).

Though Africans were considered temporary residents, native villages were also established at the time and home ownership was encouraged. As the number of black Africans living and working in urban areas increased, there was support from the public health sector to control the spread of disease. This provided additional justification for isolating communities in urban areas (Maylam 1995). Mechanisms other than legislation were used to control residential patterns such as writing racial restrictions into deeds. Grants were only given to housing complexes where race was explicitly defined (ibid). Similarly, post-WWII city reconstruction schemes contained explicit racial zoning (Mabin and Smit 1997).

While urban segregation was implemented for a variety of reasons, it was largely an instrument of labor control and capital accumulation. Increasing industrialization attracted urban migrants and the 1946 census showed that urban black populations were larger than white populations (Mabin and Smit 1997). However, segregation also served as a strategy to control the movement of Africans between rural and urban areas (ibid, Maylam 1995). As Maylam (1995:26) argued, "Residential racial segregation could be in the interests of capital for two main 
reasons: first, in facilitating labor control and second, in releasing land for industrial purposes." These segregation practices also intended to divide the working classes by maintaining a racial division of labor while protecting white job security (ibid) through the establishment of color bars $^{2}$. Labor in urban areas was so tightly controlled that both employers and employees were required to report all vacancies and changes in employment. Excess laborers were referred to a district labor bureau, providing labor to farms and more remote areas (Hendricks 1990, Thompson 2001).

While restrictive labor regulations were the main lever of control for urban influx, the Urban Areas Act of 1950 solidified the segregation policies already practiced by most municipalities. The act provided a foundation for comprehensive influx management where the largest number of forced removals occurred in and around urban areas (McCusker et al. forthcoming). Other legislative measures taken to protect white workers and control the labor force were the Native Building Workers Act of 1951, which prohibited Africans from partaking in skilled building work outside of their own areas, the Native Labor Act of 1953, which redefined "employee" to exclude Africans, and the 1956 Industrial Conciliation Act, which extended job reservations based upon race to include skilled and semiskilled labor (Feinstein 2005). In this sense, the state was effectively able to manage the flow of black, African workers through a complex permit process. Through forced removals and the permitting system, black urban populations were kept under physical control. Yet they were close enough to be mobilized when necessary (McCusker et al. forthcoming). This required a delicate balance because exclusionary labor practices could actually threaten the labor supply (Maylam 1995).

Planning for black townships became increasingly centralized over time and

\footnotetext{
${ }^{2}$ Color bar refers to the way in which job postings were limited based upon race. For example, skilled jobs were reserved for whites only.
} 
municipalities turned control over to the Bantu Affairs Administration Board. After a period of significant densification in the 1950s and 1960s, urban planning was characterized by elimination of shack settlements and the building of massive townships (Mabin and Smit 1997). Population growth in the 1970 s created more stress on existing townships and additional informal settlements were built (Maharaj and Narsiah 2002). In spite of population growth and changing labor regulations, new policies in the late 1980s removing segregationary legislation did not seek to reverse the effects of apartheid urban legislation (Christopher 2001). Residential integration and desegregation were largely left to market forces and no concerted effort was made to "undo" the apartheid city (ibid).

\section{Peri-urbanization}

Informal settlements grew after the end of apartheid due to the lack of urban housing options. The Free Settlement Act of 1989 opened several areas to all race groups (Maharaj and Narsiah 2002), creating racially mixed areas on the edge of central business districts. This contributed to a sharper class character of urban space (ibid). As deracialization progressed, access to the labor market remained vital for individuals entering the market for the first time, a large contributor to labor market growth (Kingdon and Knight 2004). In the absence of economic expansion, migration from the rural areas to informal settlements on the urban margins increased (Christopher 2001).

Many individuals believe that living close to the city will increase their chances and opportunities for finding employment. Yet, settlements on the urban fringe of cities have been difficult to quantify or define for many years (Sadiki and Ramutsindela 2002, Simon et al. 2006). Simon et al. $(2004,2006)$ have argued that peri-urbanization should be conceptualized as 
a continuum between urban and rural produced by the confluence of urban and rural processes. In peri-urban areas, different locations display more urban or more rural qualities. There are no discrete lines indicating peri-urban boundaries as distinct from urban or rural, and the potential to have pockets of more urban or more rural remains (Simon et al. 2004).

These conceptualizations of peri-urbanization have been reinforced by Sadiki \& Ramutsindela (2002) who wrote that the flows between the rural and urban as well as the dynamics of peri-urban space make it difficult to divide between the two. They are reflective of the function and activities of both places. Mbiba and Huchzermeyer (2002) considered periurbanization to be an interface between the urban and the rural, emphasizing the linkages, flows of resources and interactions as the primary processes creating peri-urban spaces. They further argued that these processes are intensified under globalization (ibid), a view similarly held by Simon et al. $(2006,2008)$. These transition zones are intimately linked to their urban core. They change rapidly following urban pressures and are influenced by the size and structure of the existing city (ibid).

Some of the processes creating these pressures are demographic composition, migration patterns, physical terrain, environmental patterns or problems, transportation networks, infrastructure development or lack thereof, land systems and local politics (Simon 2006, 2008). These dynamic processes work together creating a "hybrid" location, blending land uses, activities, differing populations, and a variety of institutional arrangements. Most contemporary thought on peri-urbanization recognizes that the existing dichotomy between urban and rural is over-simplistic (Simon 2008). In the South African context, peri-urban zones are largely a product of lasting apartheid structures (spatial and social) as well as the drive for economic stability and security. Previous apartheid townships have been resettled and expanded as peri- 
urban spaces.

\section{Economic and Industrial Decline}

Changing economic conditions and challenges through the latter half of the twentieth century played an important role in facilitating migration towards urban areas. These changing conditions can be traced to shifting economic policies, once dominated by state intervention. In contrast, new and current policies are more market oriented. Former state control over the labor market contributed to the foundations of a South African economy based on industrial expansion and was supported by a strong demand for gold from 1948 to 1973 (Thompson 2001, Fine and Rustomjee 1996). An abundance of unskilled labor was beneficial to economic growth until the 1960s and 1970s. Economic growth increased in manufacturing and service sectors, which relied more heavily on skilled and semiskilled labor (Schneider 2003). Economic success in the 1950s and 1960s was short lived as the economy was rocked by oil shocks in 1973 and 1979-1980 (Feinstein 2005). It was also limited by the manufacturing sector's failure to achieve export led growth (Fine and Rustomjee 1996, Moll 1991). Industry in South Africa was tightly linked to both the mining and financial sectors of the economy, and the finance sector established economic control by the late 1980s (Fine and Rustomjee 1996). This was accompanied by an over reliance on foreign technology (Moll 1991).

Growth was further limited by labor controls and the inefficiencies they generated, and was a significant concern by the 1960s (Feinstein 2005). Firm level rigidities, restrictions on labor mobility, and insufficient levels of training, combined with a lack of skilled and semiskilled workers also contributed to a weak manufacturing sector (Moll 1991). In spite of this, official labor and job reservation policies remained firm. Meanwhile, significant problems 
confronted mining from the early 1970s onward, as global demand decreased and gold extraction became more costly due to lower quality, and deeper ores being exploited (Feinstein 2005).

From 1973 through 1994, the economy experienced a period of stagnation and inflation, while its overall performance continued to deteriorate (Feinstein 2005). Economic policy focused on an inefficient import substitution industrial model and exporting industries were not able to maintain competitiveness (Moll 1991). South Africa's national industrialization program was inefficient and sub-optimal while regulations hampered efficient labor allocation by preventing firms from capitalizing on a cheap black workforce. This was compounded by trade sanctions in the late 1970s (ibid) and full economic sanctions in 1985 as countries around world began to apply pressure to end apartheid (Thompson 2001). In spite of the removal of all legal forms of job reservation by 1986 (Moll 1991), there had been a general loss of business confidence. This, combined with the inability of the mining sector to pull South Africa out of stagnation, created a bleak economic situation (Feinstein 2005). As Feinstein (2005:210) wrote, "The engine that had driven the South African economy forward so powerfully for 100 years was no longer functioning".

General economic malaise in the 1970s caused the creation of a large pool of unskilled workers unable to find employment. Highly regulated human capital, expense of apartheid and decentralization policies all outweighed the benefits of unskilled, cheap, African labor and contributed to the economic problems facing the country (Feinstein 2005). By 1989, profits in all industries except finance were declining. The General Agreement on Tariffs and Trade (GATT) further eroded South Africa's ability to compete internationally (Bond 2005). Industry suffered a double blow by the end of apartheid protectionist policies (Barchiesi 2008). The needs of manufacturing had long diverged from those of mining and farming and the economic downturn 
exacerbated this. Productivity levels in industry also continued to decline (Hendricks 1990). As a result, the manufacturing sector underwent major restructuring post-apartheid and experienced declines in mining, military production, and further industrial decentralization (Rogerson 1996). Rationalization, downsizing and reorganizing, in the manufacturing sector reduced the number of jobs and placed greater demands and expectations on the workers. Changes in ownership were often accompanied by contract renegotiations, further weakening the position of labor (Narsiah 2002).

Furthermore, growing market competition, determined managerial drive, new technologies, out sourcing, and subcontracting contributed to restructuring and declining industrial employment (Barchiesi 2008). Aging capital, industrial decay, and under investment in labor-intensive sectors heightened these concerns (Marais 2011). The economic issues of the 1970s and 1980s persisted into the 1990s and the democratic transition era. New investment was largely subsidized and contradictory to the labor-intensive approaches that previously dominated the apartheid economy (Bond 2005). New economic policies of the democratic government, which aimed to grow the economy, redistribute wealth, and provide jobs, fell short of these goals. By 1998, Reconstruction and Development Programme (RDP) funds were being diverted to private development initiatives. The Growth Employment and Redistribution (GEAR) program was less than effective at creating jobs and resulted in mandated job cuts from 1994 to 1999 (Marais 2011). The African National Congress's (ANC) economic policies were strongly influenced by the World Bank and focused more on deregulation and market principles than economic equality (Narsiah 2002, Marais 2011). The adoption of GEAR also left the South African economy highly susceptible to major shifts in the global economy, such as the 2009 recession, when GDP fell 1.9 percent (Marais 2011). 
As South Africa moves further away from the apartheid era, significant gaps in economic and social inequality remain. Economic and social policies, such as GEAR, have been implemented by the national government with specific goals to generate socioeconomic development and stimulate job growth. However, one of the main issues facing individuals today is unemployment and decreasing wage rates as these policies fall short on their promises (Marais 2011). Unequal racial economic opportunity remains a concern as black South Africans had 35\% less of a chance of employment than white South Africans (Kingdon and Knight 2004). The contradiction between availability of employment and the inability of households to reproduce requires a level of negation if change is to occur and potential social unrest is to be avoided.

\section{Recent South African Unemployment}

Rising unemployment levels have been well documented in South Africa (Barchiesi 2008, Rogerson 1996, Bhorat and Hodge 1999, Bhorat et al. 2002, Bhorat 2004, Kingdon and Knight 2004, 2007). Barchiesi (2008) has asserted that high unemployment works to undermine wage labor as a vehicle of social advancement, particularly for black African workers whom historically were treated unfairly. He called attention to the fact that in post-apartheid South Africa, many black households have more civil liberties but remain confronted with limited economic opportunities. Neo-liberal economic policies, characterized by fiscal austerity, deregulation and privatization, have continued to contribute to societal inequality, leaving the black working class increasingly vulnerable (Barchiesi 2008, Narsiah 2002).

In an attempt to account for changes in the labor market as a contributing factor to unemployment, Kingdon and Knight (2007) examined increases in the labor pool which were 
unaccompanied by increases in the demand for labor (see also Bhorat and Hodge 1999, Banerjee et al. 2008). Expansion of the labor pool is partially explained by the lifting of apartheid labor policies that restricted the types of jobs Blacks and Coloureds ${ }^{3}$ could obtain (Kingdon and Knight 2007). This was combined with decreases in unskilled employment opportunities in industry and a worldwide crisis in mining (Feinstein 2005, Bhorat and Hodge 1999, Bhorat 2004). The resulting labor surplus of unskilled workers resulted in high unemployment (Kingdon and Knight 1999, 2000, 2001, 2004, 2007). They concluded that the formal economy has not grown enough to absorb available labor and informal market revenues are not high enough to entice entry, resulting in the divergence between labor supply and demand (Kingdon and Knight 2007).

\begin{tabular}{ll} 
Geographic Area & Unemployment \\
South Africa & $29.8 \%$ \\
Limpopo Province & $38.9 \%$ \\
& $50 \%$ of the working population determined economically inactive \\
Capricorn District & $37 \%$ \\
Polokwane Municipality & $32.4 \%$ \\
& $42 \%$ Youth Unemployment Rate \\
\hline
\end{tabular}

Table 2-1: Unemployment figures. Data from Statistics SA South African Census 2011.

Workers are not evenly affected by unemployment rates, which vary significantly by race and

\footnotetext{
${ }^{3}$ The term "Coloured" refers to those brought to South Africa as slaves and their descendants who are often of mixed race. It can also include those of Indian decent though they mostly came to South Africa as indentured servants (Lemon, 1978) and were their own race category.
} 
gender. Africans face unemployment rates higher than the other race groups, and women experience higher rates than men. African unemployed persons are more than twice as likely to never have worked than other races before entering the workforce. Similarly, those having lived in a bantustan are 16-19\% less likely to have worked. Black Africans are also less likely to leave the workforce voluntarily (Kingdon and Knight 2004). The 2011 South African Census (Statistics South Africa 2012) identified the national unemployment rate as $29.8 \%$. Of all nine provinces, Limpopo had the highest unemployment rate in the country (Table 2-1 \& Figure 2-1).

\section{Formal and Informal Wage Labor in Limpopo}

Formal and informal labor in Limpopo takes several forms. An individual working in the informal sector, or "informal worker", is someone who is "in own account activities and working for employers who are not VAT-registered" (Kingdon \& Knight 2007: 824), while formal employees are only those receiving a formal contract ${ }^{4}$. The informal sector has been unable to absorb surplus labor because is it underdeveloped. Rather than growing together, formal and informal economies are becoming further separated. While the formal sector possesses characteristics of a middle-income country, the informal sector still retains those of a poor, less developed country (ibid). It should be noted that wage labor does not always constitute formal labor, and many working in the informal sector of the economy obtain wages. The number of individuals with formal employment contracts is decreasing and one-third of workers in the country are employed in contingent jobs (Barchiesi 2008).

\footnotetext{
${ }^{4}$ VAT = Value Added Tax or someone who is registered with the government and taxed as a business or institution.
} 


\section{South African Unemployment 2011}
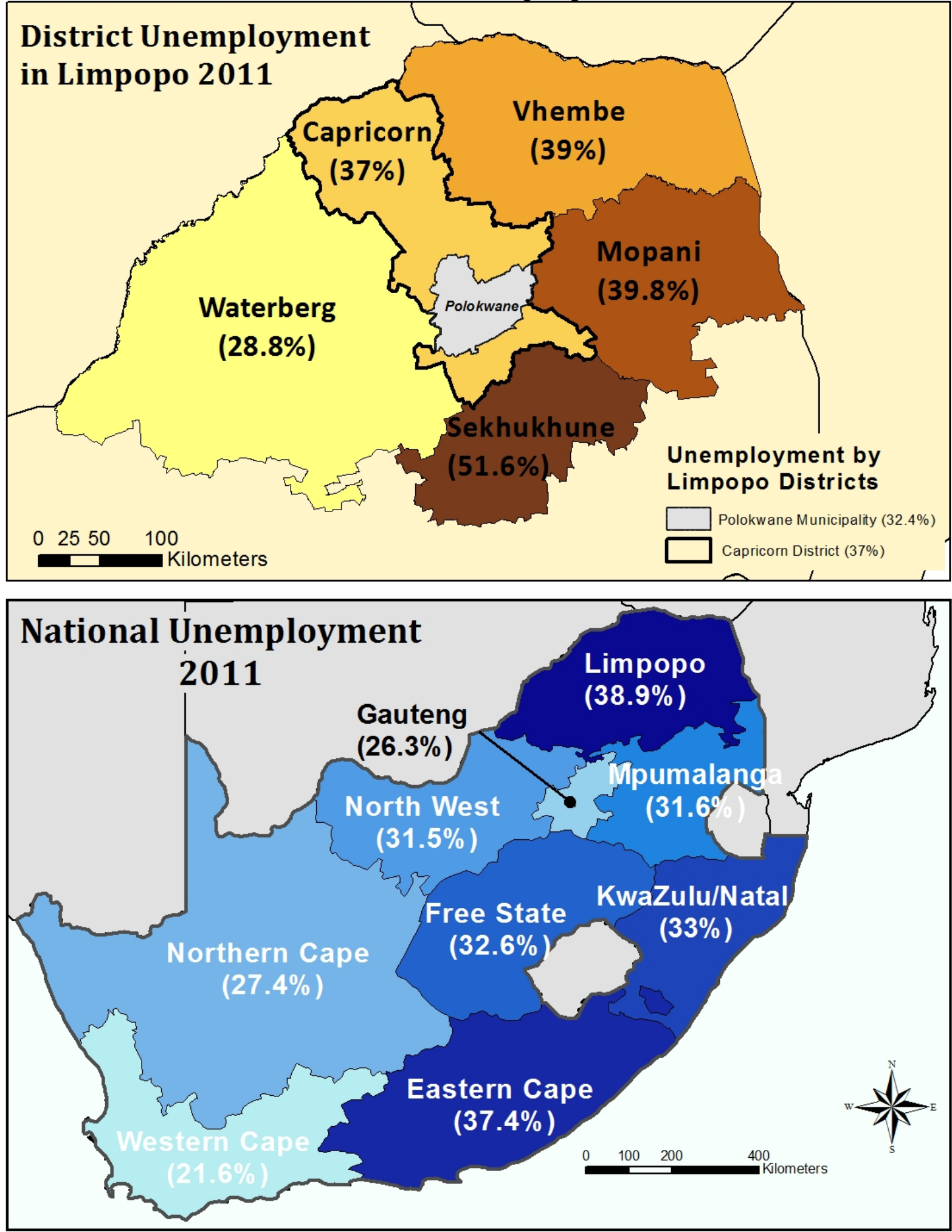

Figure 2-1: Statistics South Africa 2011 Census Unemployment Data 
Furthermore sixty-five percent of the waged population is poor, and earning less than R2500 5 (US \$333) per month (ibid). This portion of the population earns significantly less than national average, approximately R9000 (US \$1200) per month (Statistics South Africa 2012). Altman (2006) has designated these individuals the "working poor". Firm restructuring further contributed to the migration of formal workers to the informal economy as well as those joining the labor pool for the first time. With informal workers maintaining higher incomes and subjective well being than the unemployed (Kingdon and Knight 2007), an expanding number of the poor have waged jobs (Barchiesi 2008).

In peri-urban areas the expansion of street vending has contributed to the growth of informal markets. Informal economic activity also includes flea markets, hawkers, taxi drivers, street barbers, shoe shiners, and sex workers. Similarly, there are a variety of home based micro enterprises such as spaza shops (small grocery kiosks), child-minding (creche), shebeens (liquor distributors), workshops, repairs, and hair dressers all of which are most commonly found in townships and informal settlements (Rogerson 1996). This research supports these claims, and expands upon previous work to illustrate the contradiction between the reliance on wage labor and the inability to access labor markets.

\section{Case Study Sites}

Polokwane is located in the center of the Limpopo Province, the northernmost province of South Africa. It has a population of approximately 627,000 people (Statistics South Africa 2012b) and serves as the economic center for the entire province. Within Polokwane Municipality, three individual research sites (Figure 2-2) were chosen based upon recent urban growth and varying levels of infrastructural development. All three sites have experienced new

\footnotetext{
${ }^{5}$ In 2008 R8.26 = US \$1, $20127.5 R=$ US \$1, $201411.5 R=$ US \$1.
} 
growth and expansion within the past ten to fifteen years as evidenced by prior land use and cover change analysis. Study Site 1, Nobody/Ga-Mothiba, is the furthest from the city, and is also part of a traditional land management community. The community is part of a ward, but it also has a group of traditional leaders who assist with the day-to-day management of the area ${ }^{6}$.

Study Site 2 is an area of near urban growth. It is densely populated and contains both formal and informal settlements. It has been designated as part of a growth corridor by the municipality and is the home of several thousand

Reconstruction and

Development

Programme Houses (RDP houses) ${ }^{7}$.

These housing units are combined with

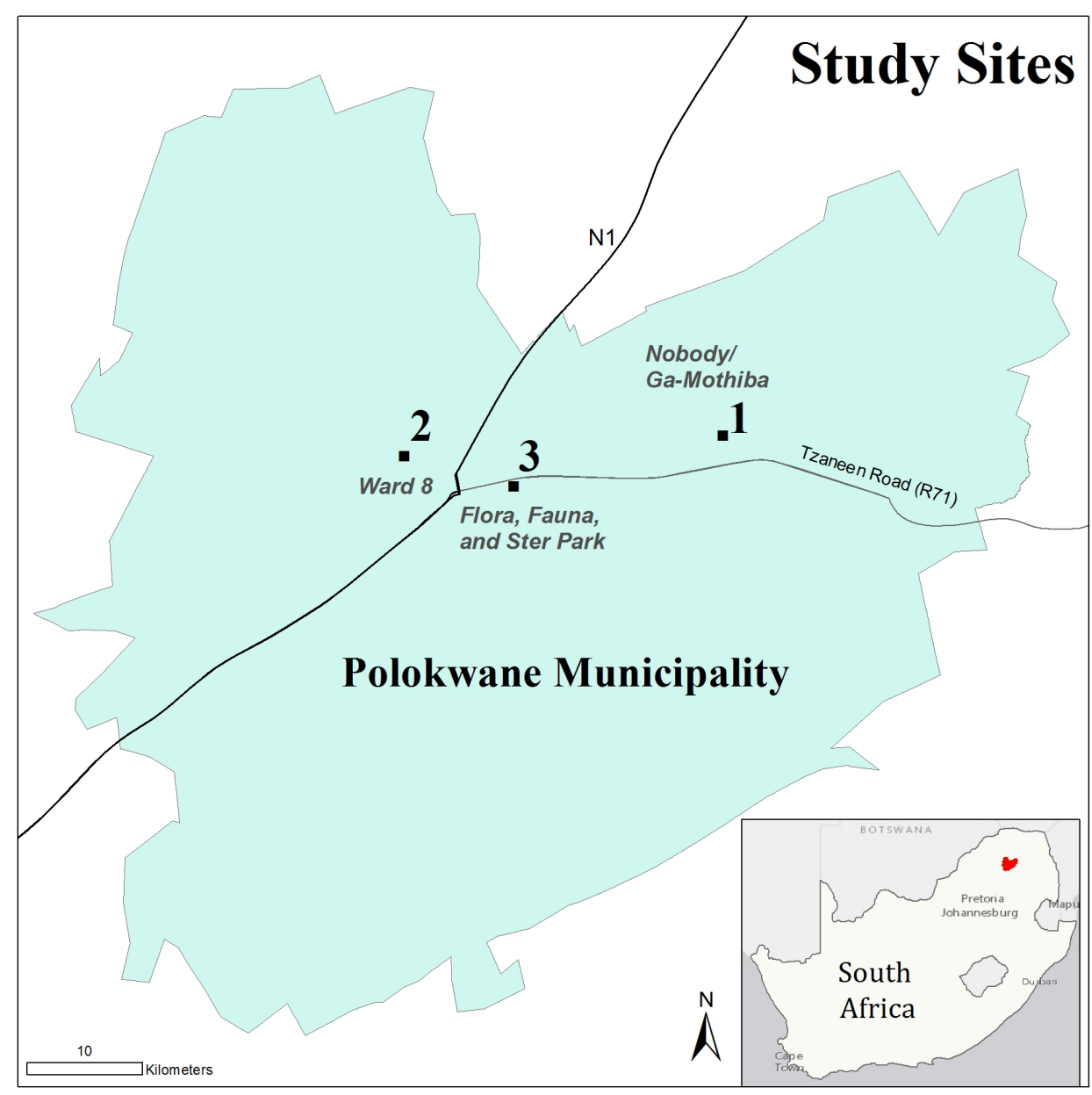

Figure 2-2: Case Study Sites

\footnotetext{
${ }^{6} \mathrm{~A}$ ward is an electoral district used in local government elections. In South Africa, each ward has its own counselor or representative and a committee which overseas various services and helps to solve community problems.

${ }^{7}$ In this instance, RDP houses are called such because of their resemblance to houses constructed under the redevelopment program. This program was abandoned in the mid-1990s for GEAR but houses are still built, and the name and purpose of the home and townships has remained.
} 
informal housing settlements, both within the individual lots, and in areas not authorized by the city. Many residents of Ward 8 were removed from previous informal or unauthorized settlements to what are now referred to as RDP Townships. Study Site 3 is an area of suburban growth outside of the central business district. The area has been suburban in nature for many years, but is experiencing major expansions north and east of the city center. The older part of the community has more middle-income households and is more racially integrated (Donaldson and Kotze 2006); however, the newest growth in the past five years has been due to very wealthy individuals building new houses just outside of these suburbs (personal observation).

\section{Research Methods}

The field research for the Polokwane case study combined quantitative and qualitative methods, through household surveys $(n=225)$, semi-structured key informant interviews $(n=60)$, participant observation, and focus groups $(n=2)^{8}$. The quantitative questionnaire was conducted in three study sites, in and around Polokwane, South Africa (Figure 2-2) between January and July 2012. Study sites were selected based upon proximity to the city, recent growth as identified in remotely sensed images, peri-urban characteristics, and income levels. Surveys were designed following a livelihoods approach (McCusker and Ramudzuli 2007, Fisher, Chaudhury and McCusker 2010) $)^{9}$. Households were chosen based upon class and race stratifications within the study site, and then randomly sampled from each community. The quantitative methods generated an economic profile for each site. The survey was designed to obtain detailed

\footnotetext{
${ }^{8}$ Quantitative data collection centered upon a questionnaire containing fifty-three questions regarding household demographics, livelihood structures, and relocation information.

${ }^{9}$ Surveys were not intentionally stratified based upon gender or race, and as a result, are not evenly distributed in some areas. When the surveys were conducted often only the women of the household were available resulting in a relatively high female participation rate (67\%). Additionally, while attempts were made to obtain as many surveys from different racial groups as possible, there is a low white participation rate.
} 
information about household income such as wages, business income, agricultural and livestock production, government support, household expenses, as well as locational information and migration choices. Descriptive statistics such as mean, median, mode and percentages were derived for most categories as well as total household income and expenditures. Survey responses were then used to generate customized qualitative interview questions focused mainly on the inconsistencies in survey responses as well as lived experiences and challenges facing households.

After the quantitative surveys were complete, semi-structured key informant interviews were conducted with community members, stakeholders, local leaders, officials, and government representatives to make sense of the problems associated with rapid urban growth, and specifically, peri-urban growth. Interviews were conducted in the local language and were translated and transcribed by the research team. This ethnographic research through semistructured interviews produced a large qualitative dataset that was used to gain a deeper understanding of individual perspectives and experiences, as previously affirmed by Valentine (1997).

\section{Deproletarianization?}

With unemployment rates high, people begging for jobs, and working class poverty even among the formally employed, a deeper theoretical investigation should be considered so that researchers and policy makers alike are well informed of the challenges individuals and households face due to sustained unemployment. The contradiction between high unemployment and dependence on wage labor, combined with firm level shifts toward temporary employment and an inability to return to subsistence farming, can be explained by deproletarianization. This 
thesis contends that the working class, or 'proletarians' exist as a social formation within the capitalist mode of production, but undergo a change as the relationship between labor (workers, proletarians) and producers (capitalists, owners of the means of production) shift (Brass 1994, 2011a, 2011b). When workers loose the ability, as owners of labor power, to sell or commodify that labor power they become 'deproletarianized'. The owners of the commodity 'labor power' are no longer able to exchange it as they choose (Brass 1994: 259). In order for a worker to be fully proletarianized, he or she must be able to personally sell his or her own labor power on a continuous basis (Brass 2011a). The dispossession of this capacity to commodify or recommodify labor is the source of the deproletarianization process (ibid). It follows that their labor ceases to be a commodity. Once labor has been decommodified, it then becomes "unfree" as workers are no longer able to bargain for their wage rate by entering and leaving the market. The ability to leave the labor market, or find another buyer of the commodity, no longer prevails within existing relations of production.

The deproletarianization argument is largely based on Karl Marx's theory that labor becomes a commodity when man has nothing else to sell (Marx 1977). Marx also defines a free laborer as, "Free in the double sense that as a free man he can dispose of his labour-power as his own commodity and that on the other hand he has no other commodity for sale, is short of everything necessary for the realisation of his labour power" (1977:169). With no alternative to making ends meet, many South Africans are forced into the labor market, or labor reserve, where there is a significant lack of buyers. The result of the need to find work and the inability to do so results in a disempowered labor force that cannot sell the only commodity to which they have access.

Brass further argues that "deproletarianization involves the reproduction, the 
introduction [or reintroduction] of unfree labor, and corresponds to a workforce decomposition/recomposition frequently resorted to by employers in their struggle with labor" (Brass 2011b: 6). Significantly, through deproletarianization, capital is able to affect a "double dispossession" of its workforce, both from the means of labor, and from the means of commodifying that labor (Brass 1994: 259). Through introducing unfree labor relations, a process of class composition and recomposition accompanies the struggle between capital and labor (ibid).

\section{Findings and Discussion}

Drawing on household surveys and interviews, this paper seeks to illustrate how disempowered labor in Polokwane is a result of deproletarianization as evidenced by the contradiction between unemployment and wage labor, the inability to sell labor on a consistent basis, and local inability to return to subsistence living. The manner in which deproletarianization replaces apartheid forms of labor control and discipline is also explored. As wage laborers are unable to sell their labor power, or enter into and out of the market at will, labor then returns or re-enters a state of what Brass (2011a) terms "unfreedom" as part of the deproletarianization process. Because labor has become unfree and jobs are scarce, wages will continue to decrease exacerbating existing conditions of poverty.

The Unemployment / Wage Labor Contradiction

Although official unemployment rates remain high, $79.5 \%$ of households surveyed reported earning some type of wage (both formal and informal). Households depend on wages more than other types of income such as money from businesses (22\%), agriculture (24\%), and livestock (17\%). Fifty-three percent of households reported receiving some type of government 
assistance. Furthermore, $27.9 \%$ of households reported that at least two household members are active in formal and informal labor on a regular basis (more than 20 days per month).

Classification of formal or informal jobs followed the descriptions provided by Rogerson (1996: 171). Considering these descriptions, $30 \%$ of those claiming wage labor work in informal sector jobs such as construction, housekeeper, gardener, or taxi driver. Meanwhile, $43 \%$ claim work in formal sector employment such as government, education, medical field, and the practice of law. Two job categories, security and retail, are indeterminable because they have elements of both formal and informal labor, which cannot be parsed out with the existing data. Indeterminate employment accounts for the remaining $27 \%$ of wage laborers (Figure 2-3).

\section{Wage Labor in the Formal and Informal Economies}

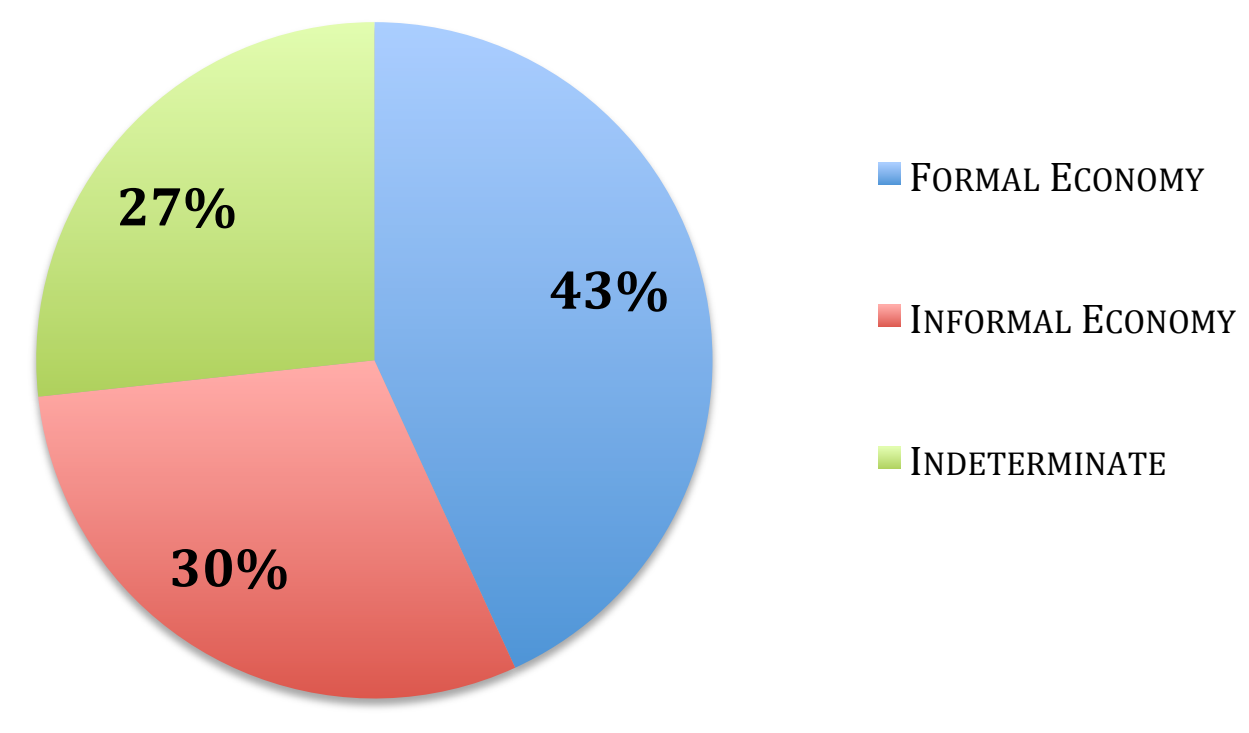

Figure 2-3: Formal and Informal Wage Earners

Of the 225 households surveyed, only $22 \%$ reported any business ventures and $40 \%$ of 
them reported losses on that business. According to the survey results, $78 \%$ of businesses operated in the informal sector, were run mostly by women, and included activities such as crèche (daycare), hairdressing, phone stand, and home auto repair. Furthermore, $62 \%$ indicated that these "informal" businesses were operated out of their home or in the local neighborhood such as door-to-door sales. Even though there is a higher percentage of individuals working in the formal than the informal sector, an economy as developed as South Africa's should have a higher number employed in the formal sector. This paper suggests that this contradiction points to deproletarianization because wage labor is a necessary component of household income but opportunities to obtain wages are scarce and competitive. Kingdon and Knight (2007) have previously demonstrated that the informal sector of the economy is unable to absorb the amount of surplus labor for a country and economy the size of South Africa. This puts even more downward pressure on wage rates and further reduces an individual's ability to obtain livable wages.

\section{Consistency of Access to Wage Labor}

As explained by Kingdon and Knight (2004), most Africans either join the labor market without ever having worked or leave it involuntarily. They spend several years, as affirmed by Respondent 41 (2012), not weeks or months, looking for formal sector jobs. Respondent 41 has been searching for formal, full time work since 2007 and even though he or she had been in the municipality's jobs database for several years, have yet to find full time work (2012). The long search for consistent employment prospects illustrates both the competitive nature of finding employment as well as the unavailability of formal work. While some of these individuals would fall into the discouraged workers category, this paper would argue the problem lies not in the perception that there are no jobs to be had, but in the reality that there are no formal jobs (see 
Marias 2011). Labor has been decommodified. They have no control over their entry into or out of the labor market or their wages. As economic liberalization and industrial restructuring continues, increases in "flexible" employment contracts are on the rise and specifically the number of permanent black workers is shrinking. As Barchiesi (2008: 122) wrote, "South Africa's employment crisis is reinforcing persistent social inequalities that see poor and low-skill Africans increasingly marginalized."

A lack of income due to unemployment has forced many people to obtain government assistance to survive. Assistance usually comes as a "social grant" based upon the number of children in the household or old age ${ }^{10}$. Costs, however, do not meet actual income from the grant. For example, households with one child may receive R270 (US \$36) per month for the maintenance of that child (less than R10 [US \$1.33] per day). This is substantially below the Millennium Development Goal (MDG) target of US \$2.50 per day or R600 (US \$80) per month. In fact, 33\% of households currently live on less than R600 per month, or R130 per person (US \$17) where the average household size is 4.6 people.

More than $50 \%$ of households (whether they realized it or not) reported spending more than they earned per month. This indicates that the wages they are receiving are not enough to meet daily living requirements or basic needs. These numbers are supported by qualitative interview data, where one focus group communicated that a household needs about R5000 (\$667) monthly to make ends meet. This is supported by the reported average household expenditure, though it considers more affluent households with higher expenses. Sixty-nine percent of households surveyed are living on less.

\footnotetext{
${ }^{10}$ A social grant is a monetary supplement that individuals receive from the government monthly to provide food and other items for the most vulnerable (e.g. children and the elderly). This is different from a government pension.
} 


\begin{tabular}{|lccl|} 
Household Reports & Mean & Median & $\begin{array}{l}\text { Percent of households with } \\
\text { less }\end{array}$ \\
& R4502 & R2540 & $69 \%$ \\
& $(\$ 596)$ & $(\$ 327)$ & \\
\hline Income & R14,129 & R1981 & $48 \%$ live on less than R2000 \\
& $(\$ 1884)$ & $(\$ 264)$ & \\
Income Sites 1\&2 & R2764 & R1378 & \\
& & $(\$ 369)$ & $(\$ 184)$ \\
& & & \\
& &
\end{tabular}

Table 2-2: Household Survey Expense and Income Data 2012

While asked a variety of questions about changes in livelihood activities, relocation, and cultural shifts, many participants kept coming back to "jobs" as a main focus of their daily lives. Even those already employed stressed the importance of having a job in the formal sector, and observed the lack of formal sector jobs to be a problem for the entire community. When asked what role the government should have in the country's development one participant responded in this manner, "Government should provide lot of jobs to the people. As household head, there are lot of challenges that you face, the most important thing, you must have understanding with your family, you must know how to support your family" (Respondent 62 2012). Respondent 67 (2012) indicated something similar, "If they [government] can provide jobs, agriculture, and the children who are growing should be able to play because they don't have places to play." 
Even those with formal employment are aware of the precariousness of their situation. In post-apartheid South Africa, formal sector employment can be unpredictable. Respondent 41 said, "I lost my job in 2007 because my employer was a cruel man. To start with, that man was a racist." The respondent also said, "I would rather not have a job than be abused" (2012). Unfair working conditions forced him to quit his job and he has been seeking new employment for five years. When asked about new job opportunities, he replied, "I do look for a job all the time but with no luck. Even right now, I have enlisted my name for the road construction job..." More telling yet was his response to the question about government helping the people, he stated, "[T] here is nepotism in the workplace and there is still racism in other employers. They would tell you to go to your grandfather Mandela for a job" (Respondent 41 2012).

The inability of households with members earning wages to meet their basic monthly needs illustrates that wage levels are too low or inconsistent to support a household. Indeed, the poverty of the working class has emerged (see also Marias 2011). This has been worsened by neo-liberal policy changes, which resulted in restructuring, and the conversion of full time employees to part time workers (Barchiesi 2008). Workers in the formal market are being pushed into the informal arena and have described wage labor as "precarious" without having any idea as to the consistency, longevity, or even legitimacy of wage labor they may obtain (ibid). The renegotiation of many full time contracts has further eroded wage labor's ability to control their access to and entry into and out of the labor market.

\section{Nothing Else to Give}

Most households are unable, and in fact do not even try, to practice subsistence agriculture as part of their livelihoods. As a means to diversify household activities, agricultural production is limited by space and access to land. Only $21 \%$ of households surveyed 
participated in agriculture and $91 \%$ of those households did so at a monetary loss, or were using other sources of income to maintain agricultural activities. Similarly a mere 13\% reported raising livestock for sale or household consumption with all but two households operating at a loss. Respondents cited a desire to farm but in most cases the accessible land was too small of a plot or too poor of quality for food production (Respondent 67, 2012). Others voiced that farming, agriculture, and livestock is more of an aspect of culture than a livelihood strategy.

The limitations to accessing land and resources prohibit households from relying on land based livelihood activities for survival. It forces them to remain in the labor market and undergo a change in labor relations. Individuals are not proletarianized because their labor is not free and they cannot return to a livelihood based on subsistence agriculture. Households don't have access to the land needed to provide enough food and some consider farming to be an unreliable source of income (Respondent 49,2012). Caught between the inability to find work and the inability to farm, deproletarianization takes place.

This is especially true in areas closest to the city, where individuals are unable to farm effectively to subsidize their food income. Less than $25 \%$ of households in Ward 8 (Site 2), the most peri-urban, reported engaging in agricultural activity. Meanwhile less than $10 \%$ had livestock of any kind. As one participant reported, "Here it's better because we have electricity [and] water, but no place for planting," and later on in the interview stated "No, agriculture is not anymore" (Respondent 61, 2012).

\section{Deproletarianization via neo-liberal capitalism}

The processes through which global neoliberal capitalism has reduced waged laborers to temporary workers is illustrated in the work of Barchiesi (2008) and the constant threat of subcontracting keeps those engaged in the formal economy disciplined, expendable, and 
compliant. Barchiesi (2008: 136) further argued that, "The gradual disappearance of wage labor as a dignified condition of social existence contrasts with its celebration in official discourse and ideological normativity."

The fundamental contradiction unearthed in this study is that many South Africans have nothing left to do to earn a living other than sell their labor; however, it has ceased to be a commodity in Polokwane. It has been argued that with access to a global industrial reserve army, capitalist firms no longer need the massive labor force that now exists within South Africa (Marias 2011). However, because local unfree labor is as cheap as migrant free labor, a new form of workforce discipline has been well established in South Africa. Labor discipline is certainly compounded by migrant labor from Mozambique and Zimbabwe. However, by examining the changing labor relations, a disempowered labor force is brought to light. Apartheid labor policies that controlled the migration, movement, flow and access to the labor market based upon race has been supplanted by deproletarianization processes brought about by neo-liberal economic policy in South Africa. Changes in the economic framework, including liberalization policies, haven’t increased job opportunities. Rogerson (2004) observes that the policy objectives for creating economic development do not always work together and can be quite divergent. However, at the same time, urban areas, often the locus for disempowered labor, have taken on a stronger class character with severe economic inequalities existing in and around the cities (Maharaj and Narsiah 2002). According to the World Development Indicators report, the GINI Index for South Africa was 57.8 in 2011 and 63.1 in 2012, demonstrating that inequality in South African has increased (World Bank 2011) over 
time $^{11}$. As Maharaj and Narsiah describe, "Class warfare is being waged in the reconstruction of post-apartheid urban spaces" (2002:93) with deproletarianized social formations as the new form of labor control emergent through neo-liberal economic policy. Local forms of this inequality and increasing class differentiation are observed in Polokwane.

In spite of poor living conditions and drastic inequalities, even when work is temporary, part time, or inconsistent, people choose to stay close to the city. The need for work combined with lack of jobs result in deproletarianization, and this social formation often resides in peri-urban spaces creating a physical manifestation of changing labor relations. While these peri-urban spaces have their roots in the structure of the apartheid city, they are attracting large numbers of rural residents hoping to escape poverty (Christopher 2001). Post-apartheid urban space is remade to accommodate the labor surplus that has migrated from former townships and bantustans to peri-urban areas. Surplus labor is now disciplined through deproletarianization, rather than forced removals, color bars, and pass laws.

\section{Conclusion}

This paper has attempted to explain how deproletarianization, the process whereby free wage laborers become unfree, has contributed to inequality and peri-urbanization in Polokwane, South Africa. While the race based labor regulations of the apartheid era no longer exist, new forms of labor discipline have (re)created centers of cheap wage labor. Economic decline and neo-liberal restructuring combined with an increased number of unskilled laborers entering the market for the first time have contributed to deproletarianization processes. This keeps wages

\footnotetext{
${ }^{11}$ The Gini Index measures the extent to which the distribution of income among individuals or households within an economy deviates from a perfectly equal distribution (World Bank 2011). Survey year for the 2011 coefficient was 2000. Survey year for the 2012 coefficient was 2009.
} 
low because laborers are unfree to effectively negotiate wages.

Survey data and qualitative interviews indicated that households are less likely to participate in multiple livelihood activities with only a few households in peri-urban areas raising livestock and participating in agriculture. Similarly, few households participate in small business ventures, which can be a key component to economic growth. While peri-urban households have the greatest reliance on wage labor, these households also have the most limited access to the labor market, rendering their labor "unfree" as defined by Brass $(1994,2011)$. Thus, limited livelihood strategies and an abundance of surplus labor concentrated in peri-urban zones contribute to the argument that deproletarianization is instrumental in creating high unemployment and poverty.

The findings of this paper contribute to theoretical debates around deproletarianization as the process of de-commodifying and thereby disciplining labor. By illustrating the deproletarianization of labor in South Africa, this article provides a better understanding of persistently high unemployment rates and the complexity of the challenges faced by the unemployed in obtaining consistent work. This is exemplified in the statement of a peri-urban resident, "If you stay at home, you can be certain you will not get a job. Moving here, you might be able to find something" (Respondent 47 2012). The examination of the reliance on labor at the household level, which is higher in peri-urban zones, and the contradiction this poses with high unemployment levels illustrates a disempowered labor force that has nothing else to sell, yet cannot sell its only commodity.

Deproletarianization occurring in Polokwane is also contributing to stark inequalities between communities, and contributes to a restructuring of post-apartheid space. Furthermore, deproletarianization exposes the manner in which wages are being kept low to capitalist 
advantage. To decrease the unemployment rate, a shift in both labor and economic policy is necessary in an attempt to address long-term meaningful solutions. By continuing to apply neoliberal market based approaches, unemployment generated by neo-liberal policies will remain high, amplifying the problem. Alternative approaches to labor and economic policy must be explored if change is to occur.

By engaging the deproletarianization thesis, the challenges of the labor market can be better understood and shape future research into problems of unemployment in South Africa. Further research on the inefficiencies of the informal economy, corruption in government and private industry, and the depth and breadth of nepotism in the hiring process will contribute to understanding additional barriers to entering the labor market. These insights will facilitate potential remediation plans and increase access to those who heavily depend on wage labor for survival. Determining the paths forward and new mechanisms for combating high unemployment levels is a crucial frontier for future research. Access to wages and the labor market is vital to survival in South Africa. Proximity to these markets is essential for maintaining access to job opportunities, whether your labor is free or not. 


\section{Chapter 3: Post-Apartheid Uneven Development of Polokwane, SOUTH AFRICA}

Abstract:

Despite the multitude of political and economic changes in South Africa in the postapartheid era, a decrease in poverty has not yet materialized. Instead, poverty is being relocated from the former bantustans and townships into areas just outside of cities, in a mixture of both urban and rural space, through peri-urbanization. Peri-urbanization processes are not only linked to the breakdown of apartheid spatial and social structures, but also to global economic change, local labor relations, and local and national governance. As these processes converge, both land uses and livelihoods in peri-urban areas are changing as individuals negotiate the challenges of every day life. By examining the historical policies, current economic conditions, and changing social relations outside of Polokwane, this research provides a more comprehensive understanding of the changing South African landscape and livelihoods in a post-apartheid era. Using an uneven development and open dialectical approach, this paper examines the social processes which contribute to peri-urban growth and the material realities of those living in periurban areas. Through mixed methods that combine quantitative surveys, qualitative interviews, focus groups, and land use change detection, the goals of this research are to understand how the lived experiences and conditions of individuals and households in the peri-urban interface are produced within an uneven development framework. The research concludes that neo-liberal economic policies combined with local labor relations and local governance are the main forces producing land use change in peri-urban areas, but are influenced by global capitalism's need to unevenly develop space. 


\section{Introduction}

South Africa is celebrating over twenty years of democracy and in that time the country has made significant progress toward dismantling discriminatory apartheid laws and regulations. While many race based socio-economic structures established during the colonial and apartheid eras have been removed from daily life, others have been reinforced. Understanding the processes that contribute to the lived experiences of South Africans is essential to further reconcile the hardships and poverty many still face. As South Africa transitioned to democracy, it also became more fully integrated into the global economic order and incorporated economic policies recommended by the World Bank and International Monetary Fund. The combination of historical economic and fiscal policy, new economic and fiscal policy, and a new political regime has had lasting impacts on South African society as a whole. Yet, kernels of previous apartheid era discourses and injustices remain.

This research examines the production of peri-urban space as a manifestation of uneven development in Polokwane, South Africa. Specifically, this paper explores the social processes occurring in and around cities, and at other scales that produce space. As individuals negotiate the challenges of their everyday lives, they produce land uses and livelihoods by engaging a variety of local, social processes. In this context, it is essential to build upon current knowledge of post-apartheid social structures and to deepen understanding of how changing political and economic policies impact individuals.

This analysis engages political economy of nature and uneven development theoretical frameworks to offer an explanation for the growth and production of peri-urban spaces; areas incorporating both urban and rural processes. Using these frameworks of analysis, this paper avoids examining change based upon a set of "drivers", but instead as the manifestation of a set 
of social processes (Carr and McCusker 2009). Through these manifestations and the contradictions between social processes occurring at the household scale, peri-urban space is produced. Simon et al. (2006) describe the peri-urban interface as the continuum between urban and rural where different places have more urban or rural qualities. Through uneven development this research contributes to the knowledge of how these spaces manifest and become dynamic areas representing the flows, linkages and interactions between urban and rural spaces.

\section{South Africa's Long Road to Change}

With the democratic elections in 1994, South Africa entered a new era of hope and change. Most South Africans anticipated that some sort of economic reform would become a reality in the next few years. South Africa's economy struggled through the 1970s and 1980s and repairing the economy quickly became the focus of the new government (Marais 2011). The election platform of the African National Congress (ANC) was a plan for redistribution, development and growth. This plan focused on meeting basic needs such as provision of food, water, shelter, sanitation, and health care (African National Congress 1994).

\section{Reconstruction and Development Programme}

The ANC's Reconstruction and Development Programme (RDP) was a policy initiative intent on correcting the wrongs of apartheid while simultaneously promoting economic growth. Addressing all of the problems brought about by colonialism and apartheid was a daunting task, but the document strived to achieve just that (African National Congress 1994). Part of an ANCled alliance with other key organizations (ibid), the RDP was a focal point of the 1993 election as the ANC used it as a manifesto to reach the people (Narsiah 2002). The goal of the RDP was to 
"mobilise all our people and all our resources to finally get rid of apartheid and build a democratic, non racial and non-sexist future" (African National Congress 1994). Following this basic needs approach, the RDP attempted to address over a five-year span many of the inequalities left by apartheid including access to jobs, health care, water, electricity and other services. The document was ambitious to say the least, and there was concern that the RDP was attempting to reduce poverty without transforming the "economic policies and practices that reproduce poverty and inequality" (Maharaj and Narsiah 2002: 91). In reality, the policy went through several iterations and the final document resembled very little of the original, peopleoriented approach. Further, the policy was also plagued by uneven and internally contradictory policies and contained logistical difficulties (Bond 2005, Marais 2011).

Both internationally and internally, free market advocates opposed the RDP and worked to undermine the needs based approach. They were successful in diluting both the funding and promises for a people based undertaking (Schneider 2003). Furthermore, the goals of the RDP never actually translated to the local level and funds were quickly diverted away from the basic needs outlined in the document toward corporate welfare and into Spatial Development Initiatives (Bond 2005). The document was continually distorted and its context changed by the Urban Development Society and Redevelopment Society (ibid). Also, the government failed to abide by the policy mandate or deliver on most basic election promises (Bond 2005).

\section{Growth Employment and Redistribution}

Outside pressure from the World Bank and the failure to deliver on promises led to discontinuation of the RDP in favor of adopting Growth, Employment and Redistribution (GEAR), a new macroeconomic strategy in June of 1996 (Bond, 2005). The new policy 
promoted fiscal austerity, export-oriented development and privatization through marketoriented growth (Narsiah 2002). Prompted by the decline in the value of the Rand as well as investor confidence, the ANC, led by Thabo Mbeki, adopted neo-liberal economic principles that focused on deficit reduction, low inflation, trade liberalization, privatization, tax cuts, and deregulation (Schneider 2003).

As with the RDP, the growth promised by GEAR never materialized. There were 100,000 jobs lost between 1994 and 1999 and the macro-economic policy failed to meet growth goals within months of its adoption (Bond, 2005). Indeed, it failed to meet targets in growth of GDP, investment, exports, and protection of the Rand (Schneider, 2003). Overall growth was ten percent lower than anticipated and fixed investment fell short by almost twenty percent. Between 1996 and 1998, every target growth metric established by GEAR was missed (Bond, 2005).

Contrary to RDP, which focused on needs, GEAR reduced social programs (Schneider 2003) and cut provincial civil servants (Bond, 2005). Interest rates did not fall and though black income rose as a share of GDP, it was largely among the top ten percent of wage earners. Those already impoverished experienced further decline in income and accompanied increasing unemployment rates (Schneider 2003). Deregulation of local markets facilitated capital flight and exchange rate instability, though it guarded financial markets (Marais 2011).

\section{Macroeconomic policy in the age of neoliberalism}

The adoption of GEAR changed post-apartheid urban planning as well by emphasizing that the economic growth would be lead by the private sector (Maharaj and Narsiah 2002). This had serious implications for the urban poor who lacked access to housing, water, sanitation, and other basic needs. South Africa's dramatic shift in macro economic policy followed the influence 
of major global economic trends instigated by major fiscal policy shifts in the United States (US) and the United Kingdom (UK) in 1979. This entailed a dramatic shift towards deregulation, tax cuts, budget cuts, and a reduction in the power of labor (Harvey 2006). Changes in US and UK economic policy had a ripple effect globally as the International Monetary Fund and World Bank quickly followed suit. Deregulation supported the protection of the finance sector and made it the center of redistributive activity (ibid). With the IMF as its main champion, the neoliberal agenda was implemented globally (ibid) and has dominated the development discourse of recent history (Murray and Overton 2011).

Global financial institutions have since dominated economy policy and influenced developing nations such as South Africa. The formation of the World Trade Organization formalized global economic influence and amalgamated with quasi-government institutions entirely outside of democratic influence. However, the rapid financialization of the global economy did not actually produce economic growth. Throughout the late 1980s and 1990s, global economic growth rates were between 1-1.4\% and decreasing (Harvey 2006). Increasing social inequality was the main result (ibid). Smith (2008b:156) describes neo-liberalism as "a global class project". Fittingly, in the South African context Marias (2011:98) notes that, "By 1996, the ANC government's economic policy had acquired a distinctive class character. It was geared, first and foremost, to service the respective prerogatives of domestic and international capital along with the ambitions of an emerging black capitalist class."

As previously noted, this had negative consequences for industrial capital and manufacturing as it opened the doors to capital flight. The main tenants of neoliberalism (free markets, deregulation, privatization) were presented as necessities to economic growth through increased exports and foreign investment (Bond 2005). Controls over the financial sector of the 
economy have been relaxed twenty seven times between 1994 and 2010. Labor-intensive industries have borne the brunt of financialization and in many cases financial markets work against industrial capital. Corporate revenues and profits are increasingly due to financial rather than productive assets (Marias 2011). Marias (2011:134) described this as the "contemporary form of global capitalist accumulation and involves the systematic use of state power to recompense the rule of capital in economic and social life".

\section{Challenges Facing South Africa}

In addition to major shifts in macroeconomic policy at the global scale, high unemployment rates have plagued the South African economy since the early 1990s (Kingdon and Knight 2007). Most policy measures taken to attempt to mitigate this problem have failed (Bond 2005, Marais 2011). While job growth occurred in some sectors of the economy such as finance and retail in the late 1990s and early 2000s, they were accompanied by job cuts in mining and manufacturing (Bhorat 2004, Marais 2011). It is estimated that $50 \%$ of South Africa's youth are unemployed and many who attend university cannot find jobs upon graduation (African Development Bank 2014). The 2011 South African Census showed unemployment at almost 30\% nationally, with some provinces nearing 39\% (Statistics South Africa 2012). Discord among South Africa's youth regarding the economic issues facing the nation are exemplified in the May 2014 elections, where the Economic Freedom Fighters (EFF) gained $6.4 \%$ of the national vote having only been established 10 months prior to the election (Onishi 2014).

The Bill of Rights as stated in the South African constitution guarantees all citizens' access to adequate housing, water, food, health care, and social security (Republic of South Africa 1996: 1255). Yet it remains a significant challenge within many peri-urban households to 
access these rights. Informal settlements, where access to water and health care are extremely limited, persist (Focus Group 1, 2012). Even in developing townships, poor road conditions reduce access to emergency medical treatment (Respondent 9905, 2012). Protests occur throughout South Africa regularly where individuals speak out against their lack of access to what have been grouped together as "services". Some of these protests have turned violent (Grobler 2009, Knoetze 2014). Many fear destruction of property and police have been quick to respond with force.

Access to adequate housing is a major concern. The growth of informal settlements as a solution creates difficult and unsafe living environments for families, and contributes to the increasing demand for government housing. Government funded housing is often called 'RDP housing' due to the similarity of housing designs to housing programs under the RDP plan. RDP houses are the primary alternative to informal structures, and they are safer than shacks, give residents access to water within the structure, and are connected to the municipality's sanitation system. The rapid growth of informal settlements, in and near RDP townships, is an indicator of the overall lack of affordable and adequate housing in urban or near urban areas, though housing remains a constitutional right. South Africa's economy has continued to experience declines in agriculture and manufacturing (Marias 2011), and job growth has primarily been focused in the service sector (ibid, Bhorat 1999). This shift in economic structure has left many South Africans unemployed with their primary focus on obtaining employment.

\section{Theoretical Approach: Using open dialectics and uneven development}

In the face of high unemployment, many South Africans continue to struggle to make ends meet. While racial capitalism no longer forms the base of this exploitation, new forms of 
capital expansion and exploitation are taking place. To disentangle these complex processes requires an open inquiry with dialectics. As Bertell Ollman (2003:12) pointedly explains, "dialectics is a way of thinking that brings into focus the full range of changes and interactions that occur in the world." David Harvey (1996:49) further describes dialectical thinking as, "the understanding of processes, flows, fluxes, and relations over the analysis of elements, things, structures and organized systems". Following this view, McCusker (2013) recommends engaging with "open", or post-Hegelian, dialectics allowing for a relational and flexible dialectics. An open dialectical approach attempts to avoid deterministic outcomes or drivers of change, and instead focuses on the social relations contributing to change.

Following an open dialectical approach, a deeper understanding of the social processes, which contribute to qualitative differences in livelihoods and land uses, can be observed. These differences combined with the movement of capital are part of the process of uneven development as conceptualized by Neil Smith (2008). In this way, as a focus of analysis, we can replace things with processes, in what Smith (2008), Smith and O'Keefe (1980), and Castree $(2000,2008)$ term the "production of space". The production of space, under capitalism as a socio-economic system, demonstrates how landscapes and social relations are re-shaped and recreated as part of capitalism itself (Smith 2008, Smith and O'Keefe 1980, Harvey 1996, Castree $2000,2008)$. The argument of the production of space is extended to the material realities experienced at the household level following the work of Carr and McCusker $(2006,2009)$.

\section{The production of space and uneven development}

The production of space examines how human and environmental processes shape and is shaped by material conditions and relations under capitalism. This analysis considers how space 
is being produced in a neo-liberal post-apartheid South Africa. Neil Smith first integrated and presented this concept in the book Uneven Development: Nature, Capital and the Production of Space $(1984,2008)$. Smith built his premise upon the idea that capitalism produces and commodifies nature to meet its needs, and in this way helps create and define the material world. According to Castree and Braun (2001), three dominant discourses have emerged about nature. The first suggests that nature is external to society and encompasses everything not influenced by humans. Second, nature is intrinsic or fixed and unchanging. Third, nature is universal and encompasses everything that exists (ibid). Defining "nature" has occupied philosophical thought for centuries, and has far reaching implications for the theoretical underpinnings of what one can say about nature (Smith 2008, Castree and Braun 2001).

In his earlier work Smith (Smith and O'Keefe 1980) reasoned that while nature is commonly viewed as external to humans or society, (an idea which continues to permeate modern thought), in reality it is intimately connected with human nature, and cannot be externalized. In an attempt to grasp the implications of defining nature, Smith (2008) further explored the dominating distinction between first nature, as produced by human labor, and second nature, as produced by human relations. Reflected in the manner in which "natural" and "social" sciences treat nature, first nature is something to be studied, measured, and quantified versus a second, human nature generated by the variety of relationships between humans. A unification of first and second nature is required for a full understanding of the complex manner in which the capitalist mode of production permeates society. Smith and O'Keefe (1980) contended that capitalist relations of production bring this relation between society and nature into focus. By focusing on "the social structures the society creates for sustaining its material existence" (ibid: 80 ), the relationship between nature and society is 
clarified. The advancement of capitalism as a socio-economic system changes the societal structure and material realities of people across the globe. As landscapes are transformed by the fixation of capital (location of a factory, clear cutting of forest, damming of a river), so are societies as they develop a distinct class structure (white collar vs. blue collar workers). It is the differentiation of class and landscape change that capitalist relations of production bring into focus.

The material manifestation of this relation becomes more dominant as capitalism and economic development advance, and their differentiated results are as Smith (2008:50) stated "the material symptoms of uneven development". In this fashion, nature is produced for exchange value through human labor. Coal is mined, forests are timbered, and water is filtered, bottled, and distributed. These seemingly "natural" resources are transformed by human labor into commodities to meet consumption needs. Yet societal demand for these commodities creates the conditions necessary for capitalist relations of production, to produce these commodities and maintain households. Smith (2008: 65) further argued that the production of nature, "takes place on an extended scale. Human beings not only produce the immediate nature of their existence, but they also produce the entire societal nature of their existence". Because the production of nature is relationally linked to capitalism, capital accumulation is essential for the reproduction of material life (ibid).

The production of material realities through transformations of nature leads to the production of space. Typically space is conceived as the relation, or sometimes distance, between concrete pieces of matter (Smith 2008). The concept of space has also been abstracted to include a variety of ideas including both relative and relational space, which is both physical and social. If, under capitalist production, nature is produced by relationships between society and the 
material world, then the relationships between material objects are also built from social relations.

For example, in the case study site of Polokwane, individuals identified a need for "recreational space", preferably in the form of a football (soccer) pitch (Respondent 9903, 2012). An undeveloped area in each of the extensions had intentionally not been built upon or developed so that it could become a recreation facility. ${ }^{12}$ In this scenario, the space has been produced as a societal need and material land use type. The physical ground does not contain a building or concrete but is mostly dirt and grass, yet it exists because society, operationalized through government, deems it both necessary and important. In the same way, capitalism works within the relationships of society and material realities to produce space for production (of goods and services) and household reproduction (livelihoods). As Smith (2008: 107) described, "the production of space also implies the production of the meaning, concepts, and consciousness of space which are inseparably linked to its physical production".

To further illustrate this in a South African context, under apartheid and racial capitalism, space was produced to racially segregate the population and provide a locus of cheap labor (see Legassick and Wolpe 1976). The relations within society, where black Africans were subservient to whites and the need for cheap labor to expand capitalist relations of production, operationalize to produce a physical manifestation in the material world. Through this process, both the bantustans and townships were created. Space was produced to control and contain non-whites (a primarily social outcome) and created densely populated but strained physical environments. The material realities and impact on the landscape of the apartheid administration have been well documented (McCusker and Ramudzuli 2007, King and McCusker 2007, Ramutsindela 2001,

\footnotetext{
12 The geographical unit of "extension" is one of the administrative sub-divisions of local wards, or voting districts in South Africa.
} 
Greenberg 2011).

Under the influence of capitalist relations of production and social reproduction, space assumes commodity status. Smith (2008) elaborated that different nature-society relations, in different cultures for example, yield different landscapes produced by the manner in which societies organize space. The different ways in which space is produced generate qualitative differences in the physical landscape. For example, urban and rural places are very different qualitatively in terms of access to goods and services, technology, infrastructure and plot size. All of these qualities have been commodified through the capitalist system and have distinct locational differences.

These locational differences, as well as physical attributes of the environment such as proximity to water, coal, oil, gas or other resources (Harvey 1985), which are vital to the production process, will influence the placement of fixed capital (such as a factory building, machinery, pipelines, or docking stations). Fixed capital is a key ingredient for capitalist production processes. As an economic system, capitalism needs all of the productive forces, labor and capital, to exist in the same space at the same time (Harvey 1985). Therefore, the production of space is vital to continued capitalist expansion because it creates the conditions whereby capitalist production can flourish. In this sense, the capitalist mode of production continuously creates space(s) conducive to productive processes. Yet, it is limited by qualitative differences that lend themselves more or less to the production process at hand (Smith 2008).

Contrary to this differentiation of space is the simultaneous equalization of space achieved by the growth and spread of the capitalist mode of production (Smith 2008). As previously discussed, deregulation, free trade, and open markets have been implemented on a global scale since the 1970s. Many countries were integrated into global capitalism during 
independence and through structural adjustment programs of the IMF and World Bank (Harvey 2006). This trend has enabled the penetration of capitalism into new places, or markets, and continues to facilitate the spread of capitalism (Smith, 2008).

As Smith (2008) asserted, the expansion of modernization is not simply an effect of progress but the "specific necessity" (2008: 127) of the capitalist mode of production and is based upon the relationship between capital and labor. Uneven development is "the concrete manifestation of the production of space under capitalism" (Smith: 2008: 123). Smith (2008: 128) further elaborated that through the expansion (economic and geographic) of the global economy, "the contradictions at the heart of capital can to an extent be displaced toward the periphery of the system".

These qualitative differences are important to the seesaw movement of capital, described by Smith (2008) as the simultaneous equalization and differentiation of space. Smith (2008) further argued that space is produced by capitalism to facilitate the expansion of the capitalist system through the development of one location over another. As the capitalist system searches for better (cheaper) conditions for production, existing locations lose their competitive edge and become under developed. Alternatively, some places are not chosen for development because the conditions required to maximize profit and expansion have not been met. It follows that places at different moments in time will be either more or less developed (ibid).

Nonetheless, because of the continuous search for favorable production costs and continuing expansion globally, the production of space is universalizing or equalizing. More places become developed as the system expands - through global systems and institutions such as the Washington Consensus, IMF, and World Bank. Yet, at the same time, other places that fail to meet the requirements are not developed and are differentiated. The movement of capital 
between these two types of spaces, to places that optimize the conditions for production and those that do not, is the simultaneous equalization and differentiation of space, or the seesaw movement of capital (Smith 2008). Ultimately it is this movement of capital, which creates uneven development manifest in the landscape as a temporary stabilization of the social and physical processes of production.

Smith's theory of uneven development has been expanded upon by Castree (2000) who maintained that uneven development provides a normative perspective, which criticizes the ecological impacts of capitalism on historical, and place specific grounds without reverting to a politics of nature itself. Similarly, Wainwright (2008) returns to an original reading of Marx reinforcing the key themes of Smith's uneven development by illustrating that Marx was aware of the geographical nature of uneven allocation of power and wealth in the world. Also, Prudham and Heyen (2011) maintained that the theory of uneven development gives geographers a critical approach to ideas, policies and perspectives, which are both political and grounded in reality. The theoretical framework of uneven development provides a critical approach to understanding how space is changing in South Africa as a result of changing livelihoods and land uses brought about through the production of space.

\section{Polokwane, South Africa}

This research examines a rapidly growing peri-urban area of South Africa where individuals are relocating from rural villages to areas just outside of cities. King (2011) argued that in South Africa the production of space and livelihoods are closely linked and that historical patterns of land use and development continue to influence society. This case study builds upon existing literature to illustrate continued uneven development around Polokwane (formerly Pietersburg). An official city of the FIFA 2010 World Cup, Polokwane is only about a three- 
hour drive northeast of Johannesburg in the Limpopo Province. Infrastructural improvements as well as the construction of the Peter Mokaba Stadium drew many people towards the city in support of World Cup preparations. In addition, the city functions as the economic center of both the region and province.

Three of the

former bantustans

(Venda, Lebowa, and Gazankulu) were located within

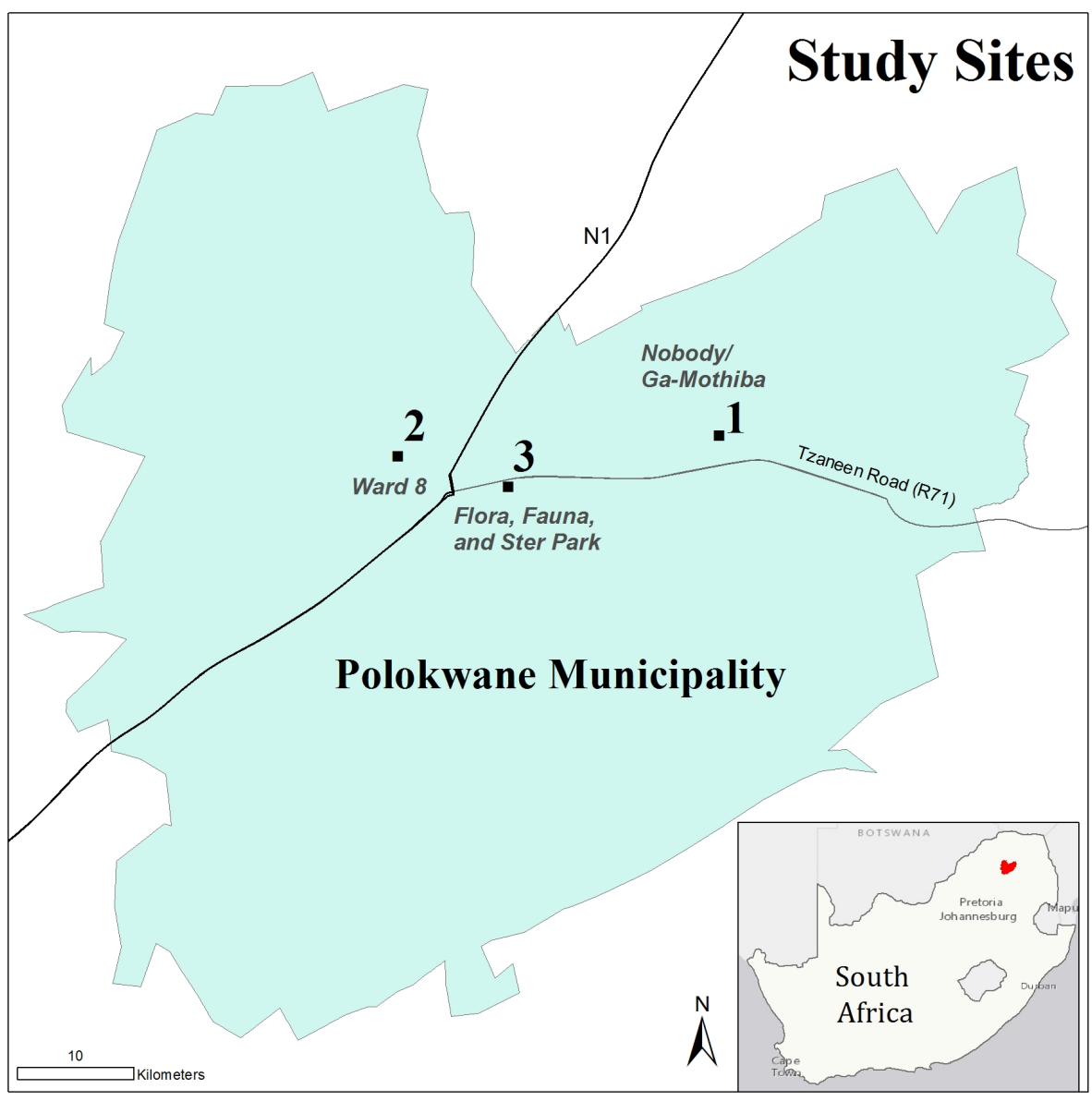
this province, though

Figure 3-1: Case Study Sites

the city was originally established as a white settlement. Originally a highly segregated city, Donaldson and Kotze (2006) describe the efforts made to create less segregated neighborhoods in the early 1990s. Several areas, including one of the research sites, have been intentionally desegregated and have significant black populations. Polokwane has since become one of the most integrated cities in South Africa.

Three study sites within the Polokwane Municipality were chosen to illustrate varying levels of economic prosperity in South Africa as well as recent growth. The first site, Nobody/Ga-Mothiba, is part of a traditional land management community. In this area, a tribal 
authority maintains control over most of the land, and an elected councilor represents the community at the municipality.

The second site, Ward 8 (also referred to as Greenside) is an area of peri-urban growth, or growth which reflects the confluence of both rural and urban life. It is densely populated with an increasing number of both formal and informal settlements. In this area, the municipality directs formal housing expansion as part of a designated spatial development area (SDA).

The third site is an area of increasing suburbanization - characterized by larger plots, gated yards and properties, and better roads and infrastructure. It covers parts of three suburban

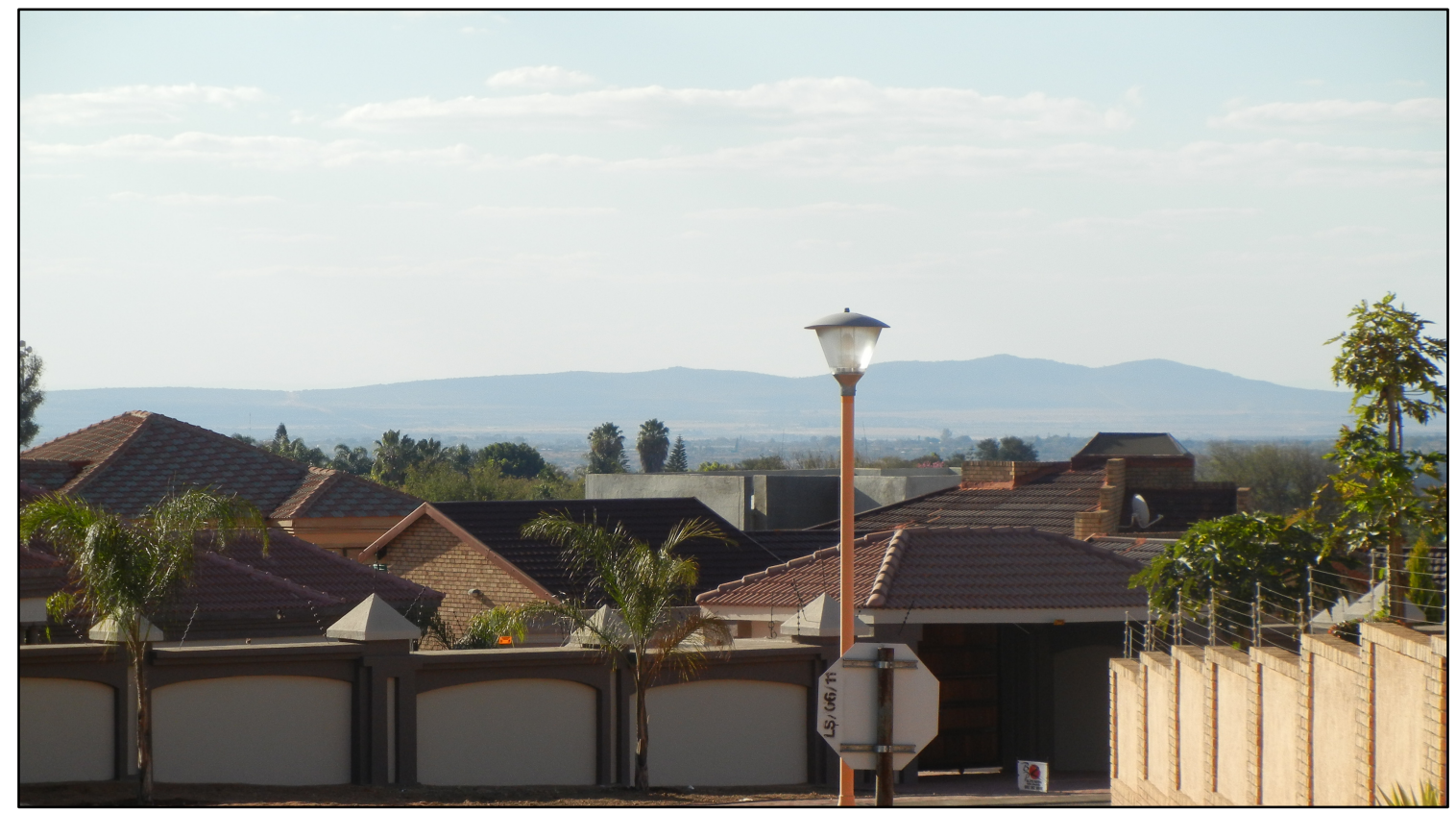

Figure 3-2: Ster Park (Site 3) 2012

communities (Flora Park, Fauna park, and Ster Park, with Ster Park being the newest). Two of these communities pre-date the end of apartheid (Flora and Fauna), but have undergone racial integration throughout the last twenty years. They are expanding both north (Ster Park) and east of the city center. The older part of the communities has more middle-income households (Donaldson and Kotze 2006); however, the newest growth (Ster Park especially) in the past five 
years has been due to very wealthy individuals building new houses just outside of the city center (personal observation, see Figure 3-2).

To gain a more complex understanding of local livelihoods in Polokwane, a combination of household surveys, semi-structured interviews, focus groups, and participant observation were conducted within the three research sites ${ }^{13}$. Surveys were designed following a livelihoods approach (McCusker and Ramudzuli 2007, Fisher, Chaudhury and McCusker 2010). Households were sampled on a semi-stratified random basis, with attempts to include households in each sub-division of the chosen study sites. Surveys were not intentionally stratified based upon gender or race, and as a result, are not evenly distributed. Additionally, while attempts were made to obtain as many surveys from different racial groups as possible, there is a low white participation rate.

The sampling method and survey were designed to create an economic profile for each community (Table 3-1, Figure 3-3). Survey responses were then used to generate customized qualitative interviews conducted with community members, community stakeholders, local leaders, officials, and government representatives to gain a deeper, more thorough understanding of the problems associated with rapid urban growth and continued negative lived experiences. This intensive ethnographic research through semi-structured interviews produced a vast qualitative dataset that was used to gain a deeper understanding of individual perspectives and experiences, as previously affirmed by Valentine (1997).

${ }^{13}$ Surveys $(n=225)$, interviews $(n=60)$, focus groups $(n=2)$ 
Table 3-1: Economic Profiles of the Sample Groups

\begin{tabular}{|c|c|c|c|c|}
\hline Study Site (\#) & $\begin{array}{c}\text { Nobody/Ga } \\
\text {-Mothiba } \\
\text { (1) }\end{array}$ & $\begin{array}{c}\text { Ward } 8 \\
\text { (2) }\end{array}$ & $\begin{array}{c}\text { Flora, Fauna, } \\
\text { Ster Park } \\
\text { (3) }\end{array}$ & Total Sample \\
\hline Average Monthly Household Income & $\begin{array}{l}\mathrm{R} 1,336 \\
(\$ 178)\end{array}$ & $\begin{array}{l}R 4,099 \\
(\$ 547)\end{array}$ & $\begin{array}{l}\text { R28,899 } \\
(\$ 3,853)\end{array}$ & $\begin{array}{l}\text { R7,611 } \\
(\$ 1015)\end{array}$ \\
\hline Median Monthly Household Income & $\begin{array}{l}\mathrm{R} 1,010 \\
(\$ 135)\end{array}$ & $\begin{array}{l}\mathrm{R} 2,030 \\
(\$ 271)\end{array}$ & $\begin{array}{l}\text { R29,000 } \\
(\$ 3,867)\end{array}$ & $\begin{array}{l}\mathrm{R} 2,012 \\
(\$ 268)\end{array}$ \\
\hline Average Monthly Household Expenditures & $\begin{array}{l}\mathrm{R} 2,178 \\
(\$ 290)\end{array}$ & $\begin{array}{l}\mathrm{R} 3,177 \\
(\$ 424)\end{array}$ & $\begin{array}{l}\mathrm{R} 10,873 \\
(\$ 1450)\end{array}$ & $\begin{array}{l}\mathrm{R} 4,330 \\
(\$ 577)\end{array}$ \\
\hline Median Monthly Household Expenditures & $\begin{array}{l}\mathrm{R} 1,730 \\
(\$ 231)\end{array}$ & $\begin{array}{l}R 2,351 \\
(\$ 313)\end{array}$ & $\begin{array}{l}\mathrm{R} 10,400 \\
(\$ 1387)\end{array}$ & $\begin{array}{l}R 2,495 \\
(\$ 333)\end{array}$ \\
\hline Average Monthly Off Farm Income & $\begin{array}{l}\mathrm{R} 2,216 \\
(\$ 296)\end{array}$ & $\begin{array}{l}\mathrm{R} 4,275 \\
(\$ 570)\end{array}$ & $\begin{array}{l}\mathrm{R} 58,217 \\
(\$ 7762)\end{array}$ & $\begin{array}{l}\mathrm{R} 13,808 \\
(\$ 1,841)\end{array}$ \\
\hline Median Monthly Off Farm Income & $\begin{array}{l}\mathrm{R} 1,010 \\
(\$ 135)\end{array}$ & $\begin{array}{l}R 2,030 \\
(\$ 217)\end{array}$ & $\begin{array}{l}\text { R29,000 } \\
(\$ 3,867)\end{array}$ & $\begin{array}{l}\mathrm{R} 2,410 \\
(\$ 321)\end{array}$ \\
\hline Percentage of Households reporting business activity & $34 \%$ & $40 \%$ & $26 \%$ & $22 \%$ \\
\hline Average Monthly Business Income & $\begin{array}{l}\mathrm{R} 1,701 \\
(\$ 227)\end{array}$ & $\begin{array}{l}\text { R3,123 } \\
\text { (\$416) }\end{array}$ & $\begin{array}{l}\text { R206,920 } \\
(\$ 27,589)\end{array}$ & $\begin{array}{l}\text { R36,615 } \\
(\$ 4,882)\end{array}$ \\
\hline Median Monthly Business Income & $\begin{array}{l}\text { R949 } \\
(\$ 127)\end{array}$ & $\begin{array}{l}\mathrm{R} 2,100 \\
(\$ 280)\end{array}$ & $\begin{array}{l}R 15,000 \\
(\$ 2000)\end{array}$ & $\begin{array}{l}\mathrm{R} 1,734 \\
(\$ 231)\end{array}$ \\
\hline $\begin{array}{l}\text { Percentage of households receiving social grants } \\
\text { (welfare) }\end{array}$ & $73 \%$ & $60 \%$ & $4 \%$ & $54 \%$ \\
\hline $\begin{array}{l}\text { Social Grant as percentage of household income } \\
\text { (monthly basis) }\end{array}$ & $91 \%$ & $65 \%$ & $50 \%$ & $76 \%$ \\
\hline Percentage of households with running water & $63 \%$ & $100 \%$ & $100 \%$ & $88 \%$ \\
\hline Percentage of households with electricity & $69 \%$ & $88 \%$ & $100 \%$ & $84 \%$ \\
\hline $\begin{array}{l}\text { Average number of years residents have been at } \\
\text { current location }\end{array}$ & 35 & 4 & 11 & 16 \\
\hline
\end{tabular}

Table 3-1: Summary of survey data. Off farm income represents the sum of wages earned (both formal and informal), business income, and other income sources such as social grants. Social grant as percentage of household income is based upon households receiving social grants. Households not receiving social grants were not included in the average. Data has been adjusted for outliers and unreported earnings. Values in USD (\$\$) are based upon the exchange rate from ZAR to USD in 2012 when the research was conducted. 


\section{The material realities of peri-urban space in South Africa}

As individuals, households, and communities negotiate day-to-day challenges, they engage a complex set of social interactions, operating at multiple scales (Smith 2008). Some households choose to diversify their livelihoods by seeking out multiple sources of income, while others rely on support from relatives, or social grants. Yet they must negotiate social processes associated with current economic conditions, local labor relations, historical racial and place based land policies, as well as the biophysical properties of the land itself. Through these negotiations, peri-urban space is produced as a physical manifestation, or a temporary stabilization of inherently dialectical processes.

As McCusker and Carr (2006) noted, there is a prevalent discourse that farming is an important livelihood strategy in rural South Africa. However, in peri-urban areas there is very little space to farm.

Seventy-nine percent of households earn wages as a main portion of meeting household needs, and

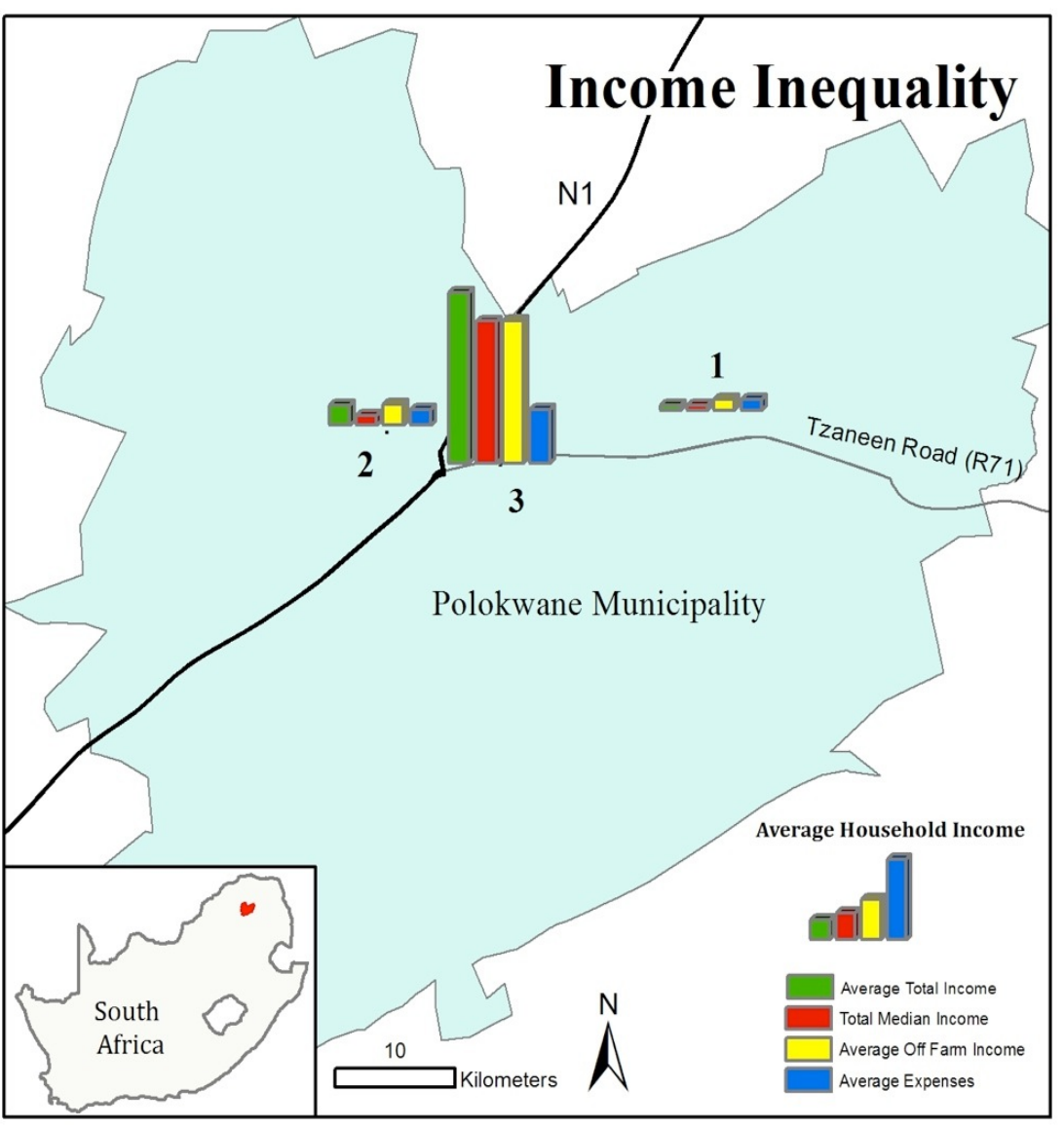
median off-farm income for 
the area is R2, $410(\$ 321)^{14,15}$. For the majority of households (74\%) off-farm income represents $98 \%$ or more of total household income. Meanwhile, $22 \%$ of households reported using off-farm income to support agricultural or business activities. Even though households rely heavily on wages or monetary income, unemployment is high in Polokwane, around 32.4\% (Statistics South Africa 2012). The high reliance on off farm income, despite high unemployment illustrates the severity of the challenges that households in Nobody/Ga-Mothiba and Ward 8 face in making ends meet monthly. Evidence of this difficulty is supported by the fact that $54 \%$ of households receive a social grant from the government and this support comprises $76 \%$ (on average) of the household's monthly income. Similarly, 50\% of households reported needing more money than they brought in each month to make ends meet. As Table 3-1 demonstrates, for both Nobody/GaMothiba and Ward 8, median household expenses are higher than median household incomes.

The gap between incomes and expenditures place added emphasis on the need to be close to Polokwane to obtain work. This gap combined with high unemployment levels and low household incomes means finding suitable housing near the city is also a challenge. Many participants spoke both of the importance of jobs and of the costs associated with searching for employment. "Even this land here is important for us because since we are not working then we are able to walk to town... when you are looking for jobs you don't have to use a lot of money, you are always walking" (Respondent 53, 2013). Because unemployment levels are high, and many individuals rely on the informal economy to provide short-term work for wages, it is vital to be close to the city of Polokwane. Meanwhile, deregulation policies also contributed to capital flight and did not encourage investment as anticipated (Marais 2011). Individuals are

\footnotetext{
${ }^{14}$ Off-farm income was used as an indicator of the amount of money households have access to during a given month. Data shows that around $20 \%$ of households reported monthly losses in terms of income due to the perceived and real expenses of agricultural production and maintenance.

${ }^{15}$ In 2012, during the time of research, the exchange rate was $7.5 R=\$ 1$, in $201410 R=\$ 1$.
} 
therefore required to negotiate the fledging economic conditions and policy prescriptions from a macro level in their individual struggle to make ends meet.

Individuals often turn to governance and local politics to transcend issues of economic scale when macro economic policies have household level consequences. The RDP document, which was both a document about economic policy and a political platform, represents the disconnect between what the people expected of national economic policy and the implementation of the program. Of the social processes individuals negotiate, local governance is even more complex, with political territories decreasing in size from the national, provincial, municipal, ward, and township levels. Each ward within the municipality has an elected counselor who appoints a local committee with representatives from each township to aid in the management of the ward. All complaints about services, roads, planning and development, crime and safety first go through the ward committee, then to the counselor, and from the counselor to the municipality.

This complex system of local governance is navigated in a variety of manners but gives community members a voice in local concerns. Across all scales of governance there are accusations of corruption. Five out of seven of Limpopo's departments were placed under national administration at the end of 2011 because of financial mismanagement (City Press 2011). One participant estimated that one billion Rand had gone missing from the province as a whole (Respondent 9911, 2012), and it has been reported that the education department alone racked up 250m Rand in unauthorized spending (Walker 2012). Funding for human settlements (RDP houses and townships) had been withheld by the national government due to "irregular tenders awarded by the provincial government” (Flanagan 2014).

Concerns with corruption and illegal tendering permeate governance in the Polokwane 
Municipality. However, individuals and households access constitutional rights by seeking government-sponsored programs such as RDP housing ${ }^{16}$. More than one-third of the participants who moved to the research sites did so for better or more adequate housing, largely in the form of a government sponsored RDP house. Increasing the number of RDP houses in the area around Ward 8 is part of the municipality's spatial development area initiative (SDA). In 2007, the municipality made a plan to develop and expand the area along the Nelson Mandela Corridor between Seshego and Polokwane and a development framework was established with specific goals to (Polokwane Municipality 2007: 6, original emphasis):

- $\quad$ Ensure the development of compact, mixed land use, diverse, life-enhancing environments with maximum possibilities for pedestrian movement and transit via safe and efficient public transport

- Ensure that low-income housing is provided in close proximity to areas of opportunity

These very specific goals of land use and development set forth by the municipality have been adopted largely to help reduce the number of individuals living in informal settlements. At least twelve households cited forced removal from shantytowns or informal settlements as their reason for moving into a new stand or location.

\section{The production of space in Polokwane, South Africa}

Situated within the specific historical context of post-apartheid South Africa, there is a complex variety of interacting social processes working to shape land use and livelihoods.

\footnotetext{
${ }^{16}$ RDP housing is a government funding housing project (Respondent 70, 2012) initiated as part of the national Reconstruction and Development Programme (King 2011). RDP houses are small 3 rooms houses and have varying quality. RDP houses in this section of Polokwane usually come with electricity and a water tap on the property though the resident must pay for the water meter.
} 
Forced removals beginning in the late 1890s and early 1900s caused dramatic changes in local livelihoods. No longer able to farm effectively in the bantustans or townships, most black Africans were required to participate in wage labor to make ends meet. The end of apartheid did not give Africans access to the land lost by their ancestors, and a return to subsistence farming is simply not possible for most. With land reform and tenure a bureaucratic, administrative, and legal ordeal, it is unlikely that subsistence agriculture will become a dominant livelihood activity soon. In addition, McCusker (2004) argues that many rural black Africans were confronted with the discourse that blacks didn't know how to farm, or were ineffective farmers. Many community farms near Polokwane, established after apartheid, were unsuccessful partially for this reason. Furthermore, the farming discourse is much the same in current periurban areas. "Agriculture is no more" Respondent 67 said (2012). "Farming is not something that you can rely on. If there is no rain you can't harvest anything, you have to have a stand by job" (Respondent 49, 2012 - emphasis added). Peri-urban residents are very aware of how their space is produced as Respondent 70 (2012) noted, "There were so many problems because sometimes you may find that you want to plant spinach so that you can have some to eat, but you find that there is no space." The municipality moved individuals to the newer extensions, part of SDA 1 (Figure 3-4), in order to physically remove the informal settlement (Respondents $61 \& 67,2012)$. The municipality also decreased the size of Disteneng in the early 2000 s to reduce the pressure on local resources and improve overall standards of living (Focus Group 1, 2012). 


\section{Peri-Urban Change 1984-2009}

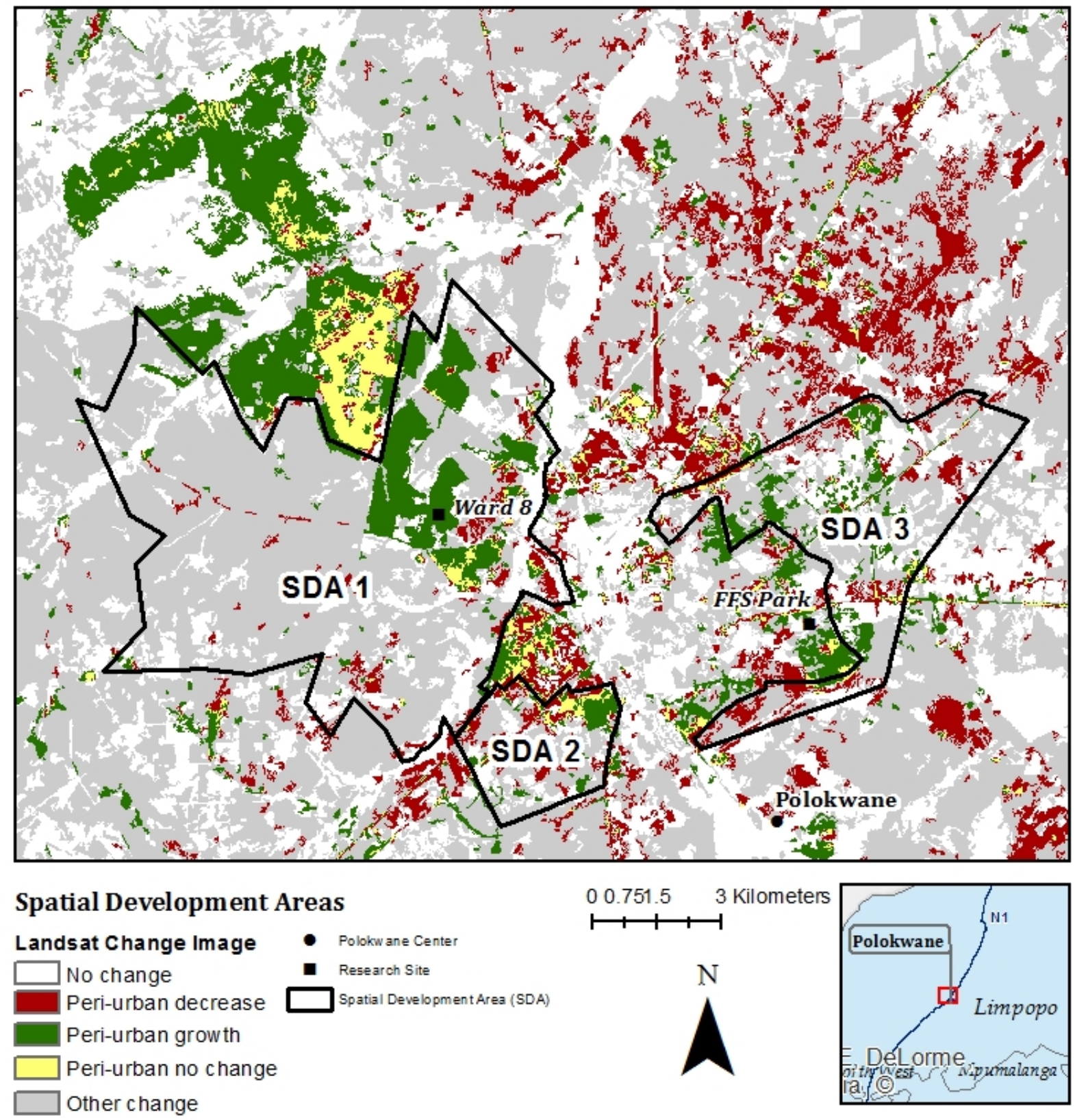

Figure 3-4: Peri-urban growth in Spatial Development Areas

\section{New Forms of Spatial Differentiation in South Africa}

While the spatial and social patterns of apartheid spatial planning are beginning to break down, new forms of spatial differentiation are growing even as vestiges of the old forms remain. 
This research contends that peri-urbanization, as a specific form of urban growth, is the physical manifestation of uneven development. Peri-urban places are produced from the combination of rural and urban processes manifest as individuals seek out all possible livelihood opportunities and negotiate challenges at a variety of scales.

The growth of peri-urban areas is intimately linked to residents need to find a job and be able to participate in the wage labor market. While wage labor is a key livelihood activity, it is paired with high levels of unemployment and results in what J. Smith (2014) has previously argued is deproletarianization. Deproletarianization means an individual's labor is no longer free to be sold. In this case, labor is no longer a commodity. Respondent 96 (2012) stated, "There are no jobs these days. In that apartheid when they promise you a job they do give [it] to you even if the salary was not that good, but we were working. Now you find that in a company there are only two surnames, the relatives. If you don't have a relative in government you won't get a job." Deproletarianization is a new method of disciplining labor and the result is that peri-urban areas have formed as a new source of this disciplined labor (ibid). The production of peri-urban space in Polokwane is a result of capitalist processes (including deproletarianization) forming a new location to source cheap labor, which benefit new capitalists and business owners as well as industrial farmers. During apartheid, the bantustans were used as a labor pool (Legassick and Wolpe 1979), but neo-liberal capitalist processes (represented by the shift from RDP to GEAR, and the creation of the SDAs) have re-located cheap available labor from rural bantustans, organized and built upon racial segregation, to peri-urban townships. This results in class differentiation and a change in the specific land uses around Polokwane, as demonstrated by severe and persistent economic inequality and the conversion of formerly vegetated or bare areas to peri-urban housing (see Figure 3-4). 
The data reported in this paper shows that the suburban development taking place to the east of Polokwane center (Flora, Fauna, and Ster Park) has better infrastructure and the residents have much higher incomes than either Ward 8 or Nobody/ Ga-Mothiba. This illustrates the qualitative differences in peri-urban growth that have emerged since the end of apartheid. Yet, these qualitative differences can be linked to apartheid planning policy as white suburbs, though now desegregated, started off with better infrastructure and have retained those resources in the post-apartheid era.

Both deproletarianization and continued uneven development are part of the current global accumulation strategy, which is characterized by the mobility of capital and capital flight of the late 1980s and early transition era. Both have contributed to the build up of the industrial reserve army - which needs to be close to the city to find work. Individuals and government together are transforming the peri-urban landscape to meet these needs. The peri-urban interface provides residents with better access to government resources (both accessing government subsidies and representation) and infrastructure (water, sewage, electricity, and housing). Because individuals have been deproletarianized they seek alternative activities for making ends meet - predominantly through government subsidies and direct cash transfers (Figure 3-5). As Respondent 53 (2012) said, "[t]he government currently gives us that one social grant which is our means of living. Although this social grant is very small, but nonetheless, the kids survive". These qualitative differences in place make the peri-urban interface a desirable location for those seeking work within existing labor relations near Polokwane. 


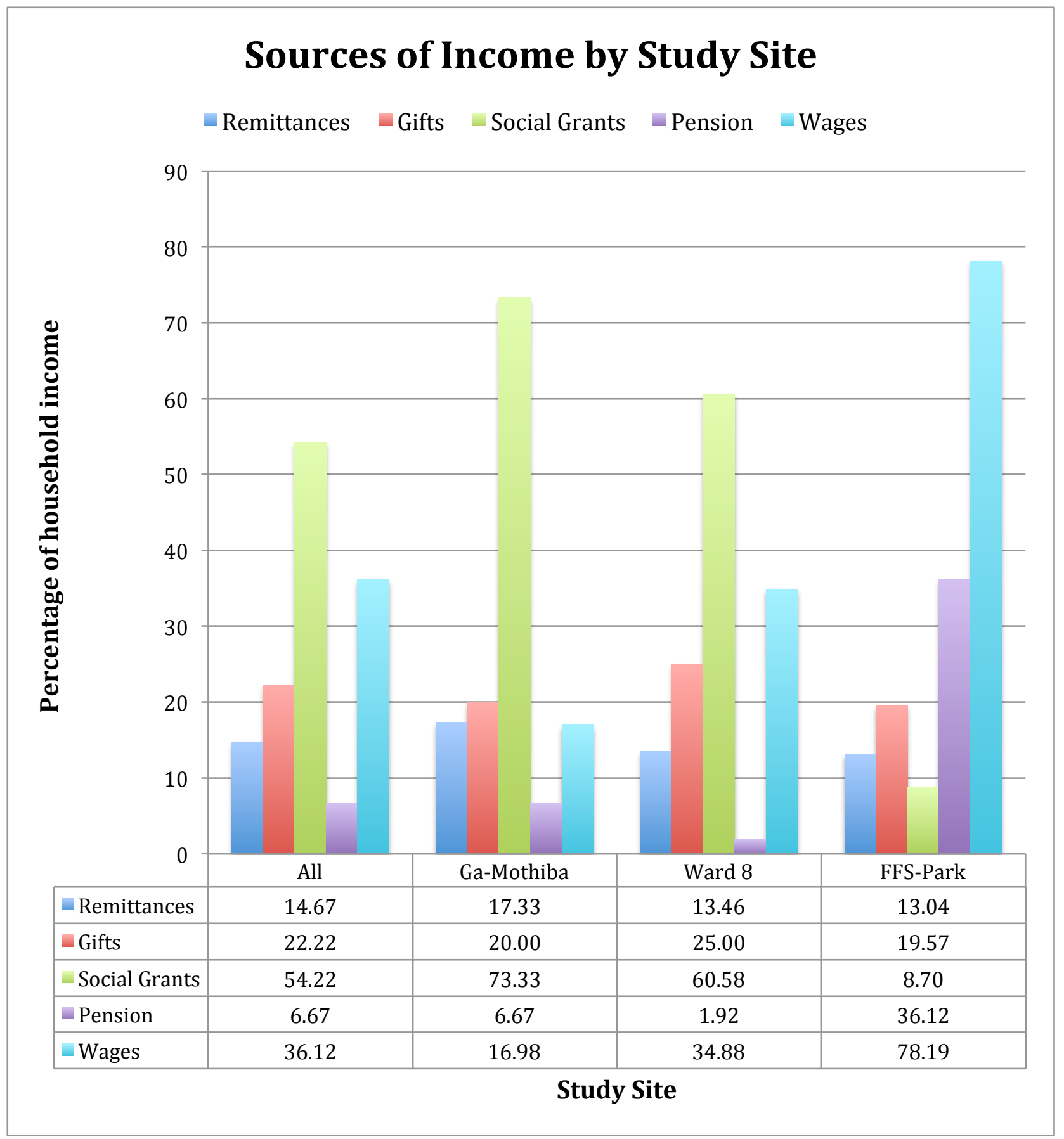

Figure 3-5: Sources of Household Income

\section{Conclusion}

Through uneven development and a critical approach to peri-urbanization, scholars and policy makers can achieve a more thorough understanding about the production of post-apartheid space in South Africa. Peri-urbanization in South Africa is a key component to urban growth in 
Polokwane as a new space of underdevelopment, which can also be applied to other South African cities such as Johannesburg and Durban. The material conditions in peri-urban areas revolve around having access to urban job markets and government resources, and by understanding these components of peri-urban growth the challenges of addressing inequality in South Africa can more readily be met. It is essential to the discussion of peri-urban areas to recognize the complex, historical, social, spatial, and economic processes that contribute to periurban expansion. In this regard, understanding peri-urban growth as well as and how local and environmental resources are changing and being challenged gives policy and decision makers in regional and local government a more comprehensive picture of local livelihoods and landscapes.

By gaining a better understanding of the complex and sometimes contradictory ways in which households negotiate the challenges to their everyday lives, researchers and policy makers can more effectively address the needs of the local population. At the root of these issues is the manner in which neo-liberal economic policy is affecting local labor relations - resulting in both peri-urban expansion and high unemployment. The policy implications are thus: to address continued uneven development in South Africa, there must be a shift in national and local economic policy. Merely planning where the influx of people is going to go is not a solution to the problem - but rather, a re-scaling of it from the rural to the urban. The national government must recognize that local planning and resources are not enough to address the systemic rescaling of poverty that is occurring in this area. Polokwane Municipality - as well as many others - will need more financial resources in order to remedy the vast inequalities and often, dire economic conditions which continue to permeate the peri-urban interface. 


\section{Chapter 4: The Co-Production of Peri-Urban SPace}

Abstract:

This paper argues that peri-urban space is produced through the social relations embedded within the co-production of land use and livelihoods. The co-production thesis maintains that there are not specific drivers of change, but rather through a combination of social processes, land use and livelihoods are coproduced by material realities and discursive formations as individuals seek to address the challenges of everyday life. This paper expands beyond more narrow approaches to understanding the post apartheid production of space by analyzing the multitude of social relations that comprise both land use patterns and livelihood decisions through a case study of Polokwane in Limpopo Province, South Africa. By focusing on a combination of lived material experiences and quantifiable land cover changes, the research demonstrates that areas just outside of Polokwane are being altered as individuals negotiate the challenges of their everyday lives. This paper draws and expands upon existing livelihoods, landuse change, and peri-urbanization literatures to argue that combinations of social processes contribute to the production of peri-urban South Africa. This research incorporates a mixed methods approach by combining qualitative ethnographic interviews with quantaitive survey data and land cover change detection. The peri-urban interface is coproduced in Polokwane as individuals participate in a variety of livelihood activities (including wage labor, business activities, and social programs) and contribute to land use patterns through their negotiations at the household and intra-household scales. However, they also engage multi-scalar processes such as macro (neo-liberal) economic policy and national level entitlement programs as part of this negotiation, the culmination of which becomes the peri-urban landscape that dominates much of post-apartheid South Africa. 


\section{Introduction}

The breakdown of social, political, economic and geographic aspects of apartheid contributed to dramatic change throughout the South African landscape. In many cases, it also resulted in a massive influx of people to the cities. The end of apartheid empowered many black Africans to move out of bantustans and townships and into formerly white areas. Through this process local landscapes were transformed by changing livelihood strategies and land cover patterns just outside of cities, contributing to the growth of peri-urban space. Peri-urban is broadly defined as a confluence of urban and rural processes, blending elements of both urban and rural livelihoods and land use practices (Simon 2008). Livelihoods and land use are intertwined in a dialectical relationship that produces peri-urban spaces. Rural conceptions of livelihoods and urban land use patterns co-produce space as a material outcome of the ways in which individuals negotiate the challenges of everyday life (McCusker and Carr 2006).

This paper illustrates the process-based conceptualizations of peri-urban space and highlights the complex processes and social relations contributing to peri-urban growth in Polokwane, South Africa. First this article reviews livelihoods and land use literatures separately. Then moving beyond these dualistic literatures, this research explores the coproduction thesis as a way of understanding how individuals meeting the challenges of everyday life coproduce land use and livelihoods. Following the coproduction thesis, the article examines literature about periurbanization and finally coalesces around an understanding of each (livelihoods, land use, coproduction, and peri-urbanization) to argue for a dialectical approach to the production of periurban space and uses the case study of Polokwane, South Africa.

Peri-urban growth in South Africa is characterized by both formal and informal housing expansion, but serious concerns arise over a lack of services: water, sanitation, transportation 
networks, unemployment/underemployment of residents, and adequate policing. Additionally, households in peri-urban areas, on average, have smaller incomes and many can be classified as ultra-poor. Understanding the processes that contribute to these challenges and simultaneously encourage people to move to the peri-urban interface is the focus of this research. This research examines local livelihoods and land use patterns as well as the institutions and policies influencing those patterns to understand the material production, or co-production, of peri-urban areas. Through this work, several core processes were identified, each contributing to the coproduction of land use and livelihoods: local and regional governance, planning policy, changes in local labor relations, national and global economic policy, and local land use limitations.

\section{Engaging the Livelihoods Framework}

In order to understand the material conditions of poverty, as well as the potential pathways individuals and households can use to foster more effective policy for poverty amelioration, a sustainable livelihoods approach was developed and adopted by the British Department For International Development (DFID) in the early 1990s (De Haan 2012). By drawing on the wellrecognized work of Chambers and Conway (1991) many researchers in the social sciences argued for a more holistic and complex approach to understanding the "web of activities and interactions that emphasizes the diversity of ways people make a living" (Scoones 2009:172). Chambers and Conway (1991) defined livelihoods based upon the capabilities, assets, and activities used to make a living. Using the livelihoods approach goes beyond mere income poverty and begins to examine the social relationships that also play a part in continued poverty and potential poverty reduction (Rakodi 2002).

A livelihoods approach to understanding household reproduction considers household resources, strategies, and outcomes as well as assets, or capital. Similarly, Ellis (2000:10) 
argues, "assets, activities, and access to these [assets and activities] together determine the living gained by the individual or household." Rakodi (2002) also maintains that livelihood strategies are often a mix of activities including seeking wage labor opportunities, borrowing and investing, starting a business, using social networks, as well as collaboration and pooling of resources. A livelihoods approach not only considers the assets a household needs or uses, but also the social relationships that both produce and control access to these assets or resources. These definitions offer a people-centered strategy to understanding livelihoods, which is a valuable way to address and gain understanding of the many nuances of both material conditions and identities swirling about in post-apartheid South Africa including class, race and gender (Oberhauser et al. 2004).

It is important to note that both households and individuals make decisions within these broad constraints and opportunities, and the livelihoods approach emphasizes that there are significant social roles and power relationships embedded in these processes. McCusker and Carr (2006) further argue that livelihoods analysis should include the social roles within and between households as well as the power circulated within households. Rakodi (2002) echoes these sentiments and cautions researchers not to treat households as "comprehensive decision making units", because internal household variability can be substantial and heavily influence decisions. Decision making at the household level is often related to gender and age - with women and children typically having less influence over household decisions. De Haan (2012:349) also notes, "[1]ivelihood activities are not neutral. They engender processes of inclusion and exclusion and power." The attention paid to intra-household variation is an important component of livelihoods analysis and motivation for using livelihoods frameworks (see Carr 2008 and Oberhauser et al. 2004). 
At the core of the livelihoods approach are several key assets (also referred to as capital): natural, economic (or financial), human, and social capital (Scoones 1998). Across multiple scales, institutions and organizations influence the assets available to households (Scoones 2009). Natural capital comprises the natural and environmental resources available to a household including water, land, soil, and firewood, while economic or financial capital considers available cash, savings, and other economic assets such as those used to run a business (for example, a cash register or pizza oven). In this sense, financial assets could also include investments. Human capital includes the skills, knowledge, and abilities available to household members. Finally, social capital observes the social networks and relationships, through family or community groups, to which households often appeal when negotiating access to these activities (Scoones 1998) (for additional examples see De Haan 2012). Social processes, including economics and governance, operating between international and local scales influence all of these assets or capitals. As Rakodi (2002:10) is quick to note, "[1]ivelihoods approaches require a realistic understanding of these assets in order to identify what opportunities they may offer, or where constraints may lie".

Because of the influence of institutions and organizations, a sustainable livelihoods approach, for example, emphasizes the complex processes intersecting to create the variety of pathways and combinations of assets that households may access. It also includes understandings of power and politics both between and within institutions (Scoones 2009). By understanding these power relationships and how they relate to and shape access to assets enables livelihoods analysis to move beyond the local level and examine wider structures of inequality (ibid). Scoones (2009: 188) further contends that, "livelihoods analysis should examine networks, linkages, connections, flows and chains across scales, but remain firmly rooted in place and 
context". In many households, both social institutions and ideologies define access to resources, assets, and activities (Oberhauser et al. 2004).

The way in which households (and individuals) combine their assets and negotiate access to those assets is considered their livelihood strategy. These strategies can also include changes in agriculture, through farming intensification for example, migration, and diversification. Households employ a combination of these activities to attempt to generate favorable livelihood outcomes (Scoones 2009). While sustainable livelihoods analysis is typically used to gain understanding of rural development processes, it is also used in an urban context. Somewhat different from the rural counterparts, urban economies are highly monetized (Rakodi 2002) giving precedence to accessing wage labor as a paramount livelihood activity (see also Hendricks 2010, Rakodi 1999, and Meikle 2002). Furthermore, social networks are less supportive because of the general mobility and diversity of local populations. In the South African context, this diversity may be based upon race, gender, language, ethnicity, or nationality. In the poorest urban areas, access and rights to land, even just land to live on, are tenuous (ibid). Within the urban livelihood context, access to transportation and energy is also included in natural capital (De Haan 2012).

One concern with using the livelihoods framework is that it lends tremendous weight to 'agency' in the decision making process (De Haan 2012). Likewise, this approach struggles to scale up to national or global levels the manner in which institutions operating at those levels are influencing local livelihood decisions. Scoones (2009) maintains that future livelihoods analyses should illuminate the social and political processes of exchange, extraction, exploitation and empowerment and include the processes of globalization into any discussion on livelihoods. Similarly, De Haan (2012) argues that livelihoods are shaped by interactions between local and 
global scales (also see De Haan and Zoomers 2003).

\section{Producing Land Use Change}

Many livelihood activities are closely related to the landscape through agriculture, housing, migration, transportation networks and other land use practices such as fuel wood gathering. Land cover and land use change analysis completed through remote sensing provides a critical tool to assess landscape change over time (Lo 1997). While land cover represents the biophysical materials found on the land (Jensen and Cowen 1999), land use is the human purpose or intent applied to these biophysical attributes (Lambin et al. 2001). Remote sensing through satellite images and aerial photography can document the patterns and in doing so facilitate understanding of landscape changes (Campbell et al. 2005). Understanding this change lies at the heart of many scientific issues including global climate change, deforestation, soil erosion and urban expansion all of which can impact livelihood strategies. By examining land use produced by livelihoods in a specific area, it allows for the landscape trends to be placed in broader social contexts and to identify complex drivers of social and environmental change (Olson et al. 2004). Land change science provides a mechanism from which to monitor growth and change at a variety of scales (Turner et al. 2007).

While using land change science as a measure of growth and change can be a powerful tool for social scientists, it is important to recognize that the images or maps produced and analyzed are snapshots in time. They represent the results, or outcomes, of processes creating landscape change rather than the actual processes themselves. It is these processes evolving through time that constitute change (Marceau et al. 2001), highlighting both the biophysical and socio-economic contributors (Lambin and Geist 2001). Schoorl and Veldkamp (2001) argued 
that landscapes are multi-dimensional and that some pathways of change can have major offsite effects. Walker (2003) also maintains that land cover change involves complex processes within a multiplicity of agents (or actors), and his research demonstrates that "forces acting in aggregate play significant roles in processes of land-cover change" (2003:377). In this context, land use and land cover reflect decisions made by individuals (ibid) often at different scales (Turner 1999).

In spite of a previous tendency for land use/land cover analysis to focus on one way causalities (Walker and Solecki 2004), it has become clear that social processes, often made at the local, individual, and household scales, influence processes of landscape change (Campbell et al. 2005, Walker and Solecki 2004, Lambin et al. 2001). To illustrate this perspective, Lambin et al. (2001:266) state "the pathways of land cover change are largely the result of causeconnection patterns operating at regional and national scale." Land use and land cover change are products of both individual and community actions (Alphan 2003), and are influenced by both internal and external factors (Campbell et al. 2005). Similarly, the direction of land use and land cover change are not always predictable due to the complex web of driving forces, which manifest at different scales (Reid et al. 2000). However, Geist and Lambin (2002) go so far as to argue that no universal link between cause and effect exists and that multiple causative factors are many and varied, without distinct pattern. Government policy is often an important factor contributing to changes in land use and land cover (Reid et al. 2000), especially when both the scale of the policy initiative as well as the scale of the change occurring is considered.

Urban areas in developing nations can especially benefit from the monitoring of growing, unplanned communities, which often develop on the outskirts of cities (Lopez et al. 2001). It has become increasingly important to measure urban expansion in order to keep local planning 
officials informed about growth (Dewan \& Yamaguchi 2009) as well as document areas requiring access to government services (Lopez et al. 2001). Remote sensing of urban areas requires an appreciation of urban temporal, spectral and spatial resolution characteristics (Jensen and Cowen 1999) and must be chosen with thought in order to assess sensitive areas in urban and suburban environments. Lo (1997) finds high-resolution satellite images useful for quality of life assessment by combining biophysical features and socio-economic features in urban analysis. Furthermore, the monitoring of planned and unplanned expansion of urban areas is vital both to assure validation of land-use plans but also to prevent formation of new informal settlements (Alphan 2003). Land use is also affected by existing rural to urban linkages (Seto et al. 2012). While much of the research on land use and land cover change focuses on the causes of change, Walker and Solecki (2004:311) argue that there must be greater effort to "unite the explanation of material processes with a political economy approach that is more inclusive". Turner (1999) suggests that environmental change comes from complex causal pathways that can only be understood through understanding the relationships between society, land-use and government. He also advocates for a mixed approach to better understand land-use dynamics in a regional and local context (ibid). Similarly, Geist and Lambin (2002) argue that underlying driving forces (of land use and land cover change) are fundamental social processes.

\section{Co-production of livelihoods and land use}

Fundamental social processes are at the core of both livelihoods and land use. These processes are embedded within landscape change and are grounded in the material world. They are directly observed in the changes over time of land cover types, and authors such as Walker (2003) and Turner (1999) support a more inclusive approach that considers the multi-scalar web 
of social processes affecting land cover change. Through the co-production thesis, a more holistic approach to understanding landscape change can be grounded in material observation without premising any one process over the others. This research applies the co-production thesis and argues that land cover/land use is co-produced with livelihoods as individuals seek to negotiate the challenges of everyday life (McCusker and Carr 2006). Carr and McCusker describe the co-production of land use and livelihoods as, "different manifestations of social processes through which individuals and groups come to understand the challenges facing their everyday lives, the various resources available to them to negotiate these challenges, and the strategies by which they can conduct that negotiation" (McCusker and Carr 2006: 794, Carr and McCusker 2009: 568). They argue that land use and livelihoods should not be construed as separate objects. Rather they should be viewed as temporary stabilizations of a variety of social processes manifest as economic, social and biophysical outcomes, influencing the ways in which individuals within and between households negotiate day-to-day life. This approach engages a post-Hegelian dialectic, which avoids dualism and tautologies and allows for multiple, overlapping and contradictory processes to come to light. As highlighted in the separate literature reviews for both livelihoods and land cover change, research in both arenas advocate for a more inclusive approach that considers the social processes, operating at a variety of scales that influence both livelihood and land use outcomes. The coproduction thesis merges the two concepts since they are both products of the same processes.

As McCusker and Carr (2006) describe, through a co-production framework, intra household dynamics, such as gender roles, are better-understood and contextualized within the larger socio-economic patterns affecting land use and livelihood change. In past research, the authors found that while intra-household dynamics affected specific livelihood diversification 
strategies and land use patterns, the underlying gender discourses were producing (co-producing) changes in both (ibid, Carr 2008). Using the co-production framework allows for the specific gender discourses present at the household level to bear weight, while explaining broader scale changes in local livelihoods and land use patterns. This enables the coproduction thesis to expand upon both the livelihoods approach and land use analyses to be more inclusive without premising structure or agency - but rather including both in the analyses.

Using this approach, Grabbatin (2008) and Grabbatin et al. (2011) explained that processes tied to rural gentrification and infrastructure developments, as well as social networks, are influencing land use and livelihood changes in rural communities of South Carolina. Individuals engaged in the production of sweet grass basketry do so through a negotiation of land use and livelihood practices and engage in a variety of social processes to continue the practice (Grabbatin et al. 2011). Similarly, Brian King (2011: 297) supported the spatialization of livelihoods and stated that there are "reciprocal relationships between space and livelihood". King (2011:298) further argued, "[t]he production of space is closely intertwined with the production of livelihoods."

\section{Peri-urban Context}

By engaging the co-production thesis, this research seeks to more fully understand the processes contributing to the creation of the peri-urban interface. The peri-urban interface, or peri-urban zone, is a dynamic mix of both rural and urban land uses and livelihoods (Simon 2008). In defining peri-urban, many authors (Sadiki and Ramutsindela 2002, Simon et al. 2004, Simon 2008) seek to avoid the dichotomous definitions ascribed to urban or rural. Rather than focus on any one definition, the peri-urban interface, or peri-urban space, can be betterunderstood as a continuum, a space between urban and rural that is not contained or discrete, but 
fluid and fluctuating with pockets of more or less urban spaces between (Simon 2008). Simon (2004:238) notes that peri-urban spaces are "characterized by a strong urban influence, easy access to markets, services and other inputs, supply of labor, shortages of land, risks from pollution and urban growth". While peri-urban spaces typically retain higher population densities, they also remain tied to rural processes. Through rural livelihood practices, peri-urban areas are highly relevant to and linked with rural development (ibid, Seto et al. 2012).

Subject to an assortment of urban pressures (Simon 2004), the peri-urban interface is influenced by a complex variety of social relations creating socially differentiated landscapes (Koti and Weiner 2006). These urban pressures are exacerbated by structural adjustment and liberalization policies (Simon et al. 2006) contributing to the growth of the urban poor (ibid). Because many peri-urban dwellers buy, rent, or construct shelter on the fringe of the city, periurbanization is often synonymous with unplanned informal settlement (Simon 2004).

\section{The Negotiation of Everyday Challenges in Polokwane, South Africa}

Peri-urban growth has become a significant characteristic of post-apartheid urban development in South Africa (see Thornton 2008, McCusker and Weiner 2003). This research examines peri-urban growth in Polokwane in Limpopo Province, South Africa, approximately three hours northeast of Johannesburg. An official city of the FIFA 2010 World Cup, Polokwane has seen rapid urbanization and has become the economic center of the region and province. Originally established as a whites-only settlement, it is in close proximity to several of the former bantustans (Venda, Lebowa, and Gazankulu) though it remained a whites-only city until the early 1990s. Since then, many neighborhoods have been de-segregating and it has become one of the most integrated cities in South Africa (Donaldson and Kotze 2006). 
This research focuses on three study sites within the Polokwane Municipality chosen based upon recent land cover changes and varying levels of local infrastructural development. All three sites have experienced new growth and expansion within the past ten to fifteen years. Study Site 1, Nobody/Ga-Mothiba is part of a traditional land management community where a tribal authority maintains control over most of the land, and an elected councilor also represents individuals at the municipality level. Study Site 2 , Ward 8 , is an area of peri-urban growth, or growth which reflects the confluence of both rural and urban life. It is densely populated with an increasing number of both formal and informal settlements. The municipality has a strong influence over the locations of residential housing expansions as part of

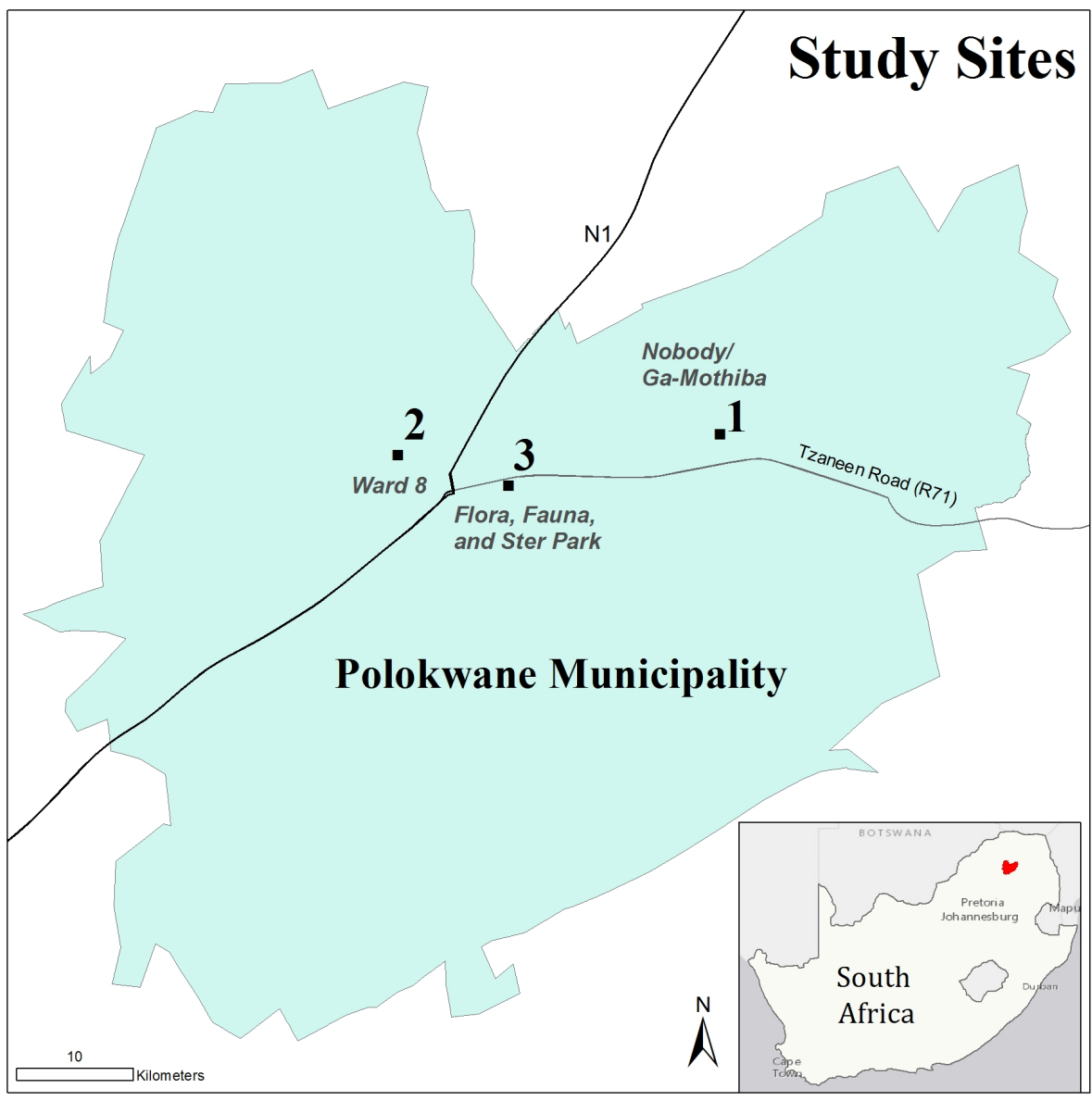

Figure 4-1: Case Study Sites the municipality's Spatial Development Areas (SDAs).

Study Site 3, Flora, Fauna, and Ster Park, is an area of increasing suburbanization characterized by larger plots, gated yards and properties, with better roads and infrastructure. These suburban communities pre-date the end of apartheid, but have undergone racial integration 
throughout the last 20 years. They are expanding both north and east of the city center. The older part of the community has more middle-income households (Donaldson and Kotze 2006); however, the newest growth in the past five years has been due to very wealthy individuals building new houses just outside of the city center (personal observation).

\section{Research Methods}

To understand the challenges facing households in peri-urban areas of South Africa, this research employed a mixed methods approach including qualitative semi-structured interviews, quantitative household livelihood surveys, and focus groups conducted in 2012. The research also used geospatial technologies to map and monitor peri-urban growth around Polokwane. A locally hired research team (three women and two men) conducted surveys and interviews in the local language, Se-Pedi (Northern Sotho) or English. Participants were chosen for key informant interviews based upon the responses to the quantitative surveys. Responses to questions about recently moving to the peri-urban interface were used to choose these interviewees, or households with contradictory statements in the survey. An example would be those who said life was better before moving to Polokwane were chosen for a follow up key informant interview. Other key informants in local and municipal government were also interviewed to provide background and policy information. During the interviews, two research team members were present, with one asking questions of the participant and the other translating for the primary investigator (PI). This allowed the PI to engage with the interviewee and ask follow-up questions as the interview progressed.

Descriptive statistics were used to assess a variety of livelihood activities for households. Information collected in the survey included a breakdown of household demographics such as 
the age and gender of all household members as well as each member's livelihood activities (where applicable). This enabled the research team to collect data about inter and intra-household livelihood variations and tie the data to both age and/or gender.

Qualitative coding grouped like responses from the qualitative portion of the survey and the semi-structured interviews. Once common themes were identified among the surveys and preliminary readings of the interview transcripts, a second and third reading and qualitative coding was conducted to tease out the main themes woven through the data. For example, after reading through all of the reasons listed for moving to their current location on the survey, response themes were identified: family, jobs, proximity to town, housing, safety, services, schools, transport, relocation, and personal preference. When respondents stated, "My parents moved us here" or "We were looking for a place of our own", the resulting code was "family". Respondents indicated that they had relocated primarily due to family pressures or changes (such as marriage, divorce, etc.). In addition, vague responses such as "to be closer to town" were more fully explored in the qualitative interviews.

This research also used remotely sensed images and GIS to calculate and visualize periurban growth in the case study sites (Figure 4-2). Landsat 5 Thematic Mapper satellite images (Path 169, Row 76/77) were classified using support vector machine classification with ENVI software. The original scene was cropped to a $15 \mathrm{~km}^{2}$ area used to assess change just outside of Polokwane. Images from 1984, 1990, and 2009 were used to gauge land cover change, representing different stages in apartheid control and subsequent development ${ }^{17,18,19}$. The 1984 image represents land cover classes during apartheid, while the 1990 was acquired at the end of the apartheid era. Landsat data from 1994, the time of transition to majority rule, was

\footnotetext{
${ }^{17}$ Landsat 5 Image 1984, Path 169, Row 76/77, Acquisition Date: 21-05-1984

${ }^{18}$ Landsat 5 Image 1990, Path 169, Row 76/77, Acquisition Date: 06-05-1990

${ }^{19}$ Landsat 5 Image 2009, Path 169, Row 76/77, Acquisition Date: 26-05-2009
} 
unavailable.

\section{Peri-urban growth 1984-2009}

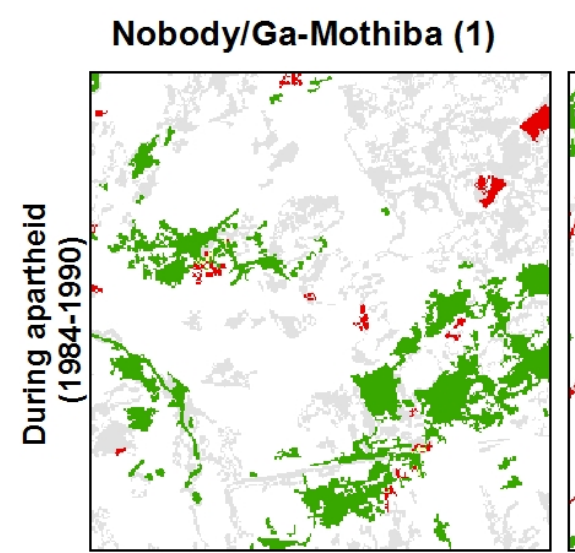

Ward 8 (2)
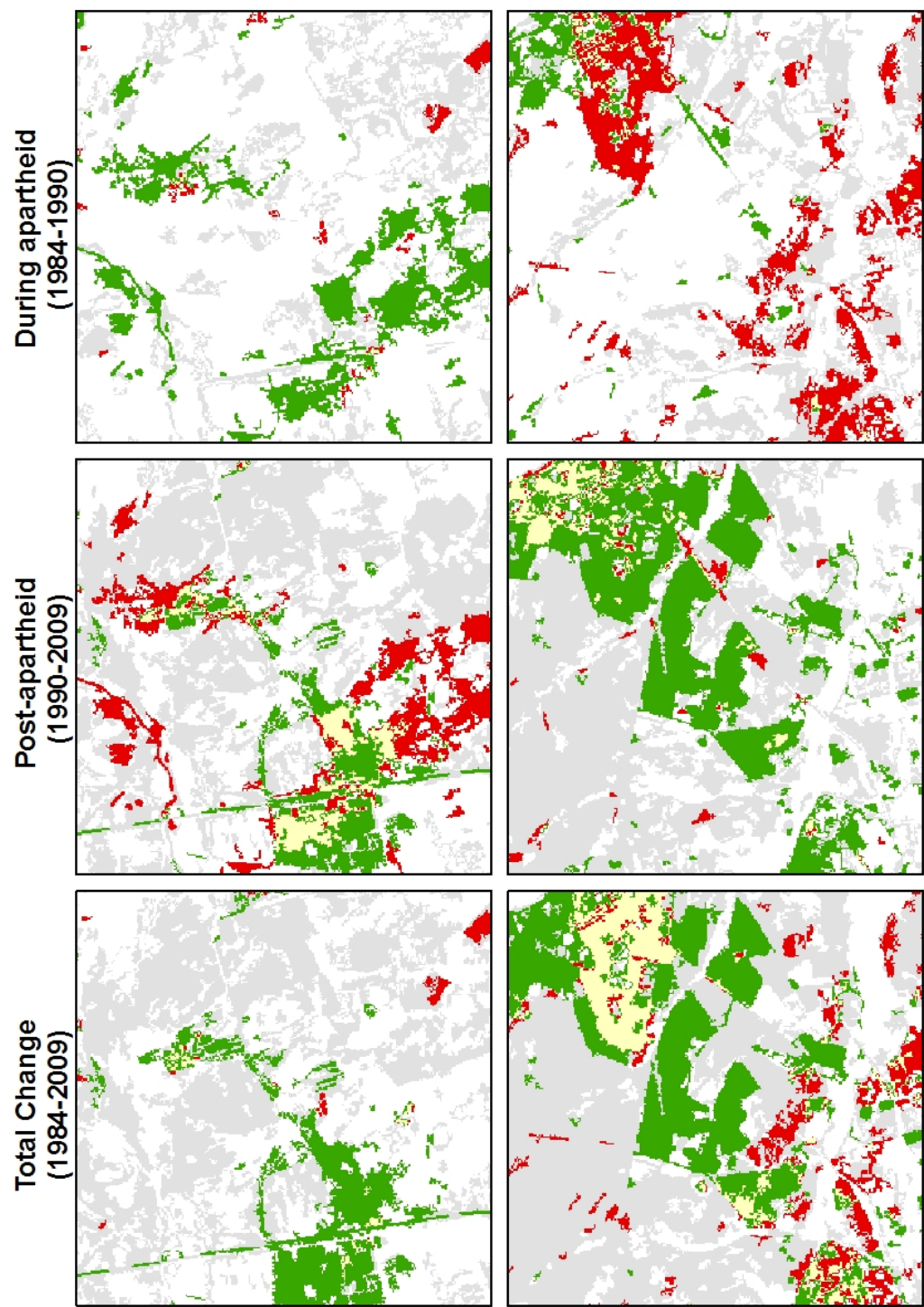

Peri-Urban Change
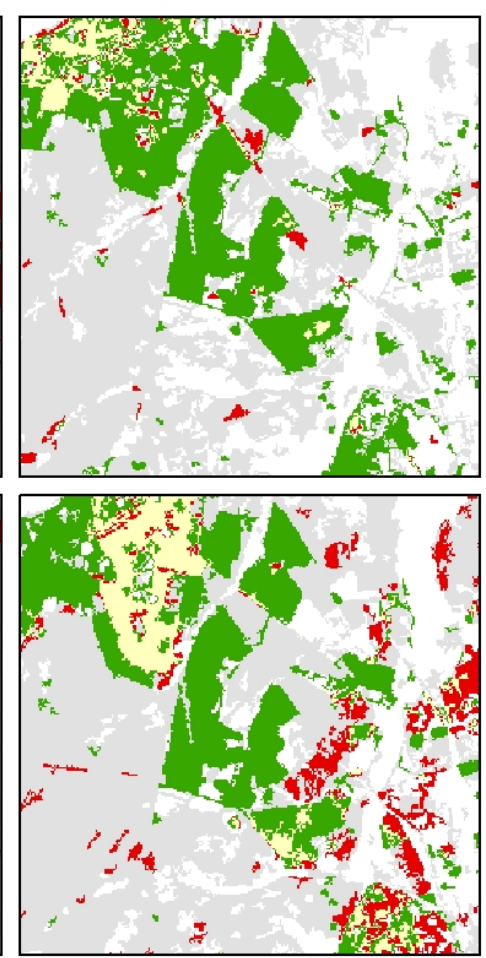

Flora, Fauna \& Ster Park (3)
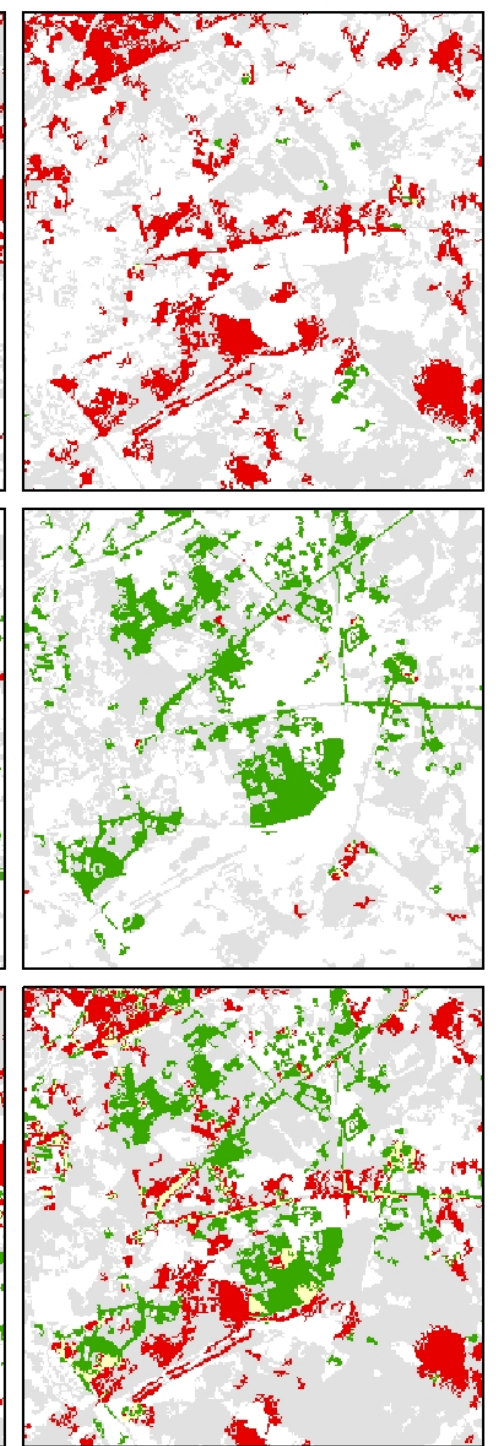

Landsat 5 Change Classes

$0 \quad 1.25 \quad 2.5$ 5 Kilometers 
The 2009 image represents the post-apartheid era. The change period from 1984-1990 illustrates that at the end of the apartheid era urban migration was not yet a dominant pattern in the landscape. Furthermore this change image documents the spatial buffer that existed around the city during the apartheid era. The change between 1990 and 2009 provides evidence of the rapid land cover changes, especially in terms of peri-urban growth, from the end of apartheid through the beginnings of the post-apartheid era.

Five land cover classes were used during the classification phase of the analysis: water, vegetation, bare, peri-urban and urban. The goals of creating this land cover change image were to visualize and quantify peri-urban growth in the region, and land cover classes were designed to highlight that growth. Change classes were condensed from the original twenty-five (representing the four possible changes from each of the five classes as well as one unchanged class) down to five focusing on peri-urban change.

The accuracy of the change images produced were: 1984-1990 (during apartheid), 75\% overall accuracy, 1990-2009 (post-apartheid), 68\% overall accuracy, and 1984-2009 (total change), $65 \%$ overall accuracy. Accuracy assessment compared the change images to panchromatic aerial photography at 1:50000 from the South African National Geospatial Information Center. Change between 1984-1990 references aerial photography series 843, 868, and 960 for Pietersburg ${ }^{20,21}$. Change between 1984-2009 and 1990-2009 also incorporated aerial photography collected in 2008 at 1:12500 scale. Also, when possible I used GeoEye imagery obtained through a GeoEye Foundation imagery grant for the areas surrounding the city ${ }^{22}$.

\footnotetext{
${ }^{20}$ Pietersburg was the former official name of Polokwane, used until 2005.

${ }^{21}$ Aerial photos used for accuracy assessment in the 843 series were collected 16/6/91. The 868 series were collected on 30/04/1983 and 1/05/1983, and the 960 series were collected 12/07/1993.

${ }^{22}$ GeoEye 1 Imagery collected on 15/05/2009.
} 
GeoEye images have 0.5 meter resolution and a transect spanning across the three study sites.

The image does not cover the entire scene used for analysis. Using ERDAS imagine I generated 300 random points across the change image and used the aerial photography to collect the reference points. I duplicated the same 300 points for each of the change scenarios completed (1984-1990, 1990-2009, 1984-2009) but collected individual reference information for each change series using ArcGIS to compare change between the two images.

\section{Livelihood Diversification and Analysis}

By examining local livelihood strategies and land use changes, a more thorough investigation of the co-production of peri-urban space can be completed. As can be seen in the

graph, more

households from

Nobody/Ga-Mothiba

participated in three

or more livelihood

activities in order to

make ends meet each

month (Figure 4-3).

Predominately,

households with

multiple livelihood

activities have more

\section{Households Engaging in 3 or more Livelihood Activities}

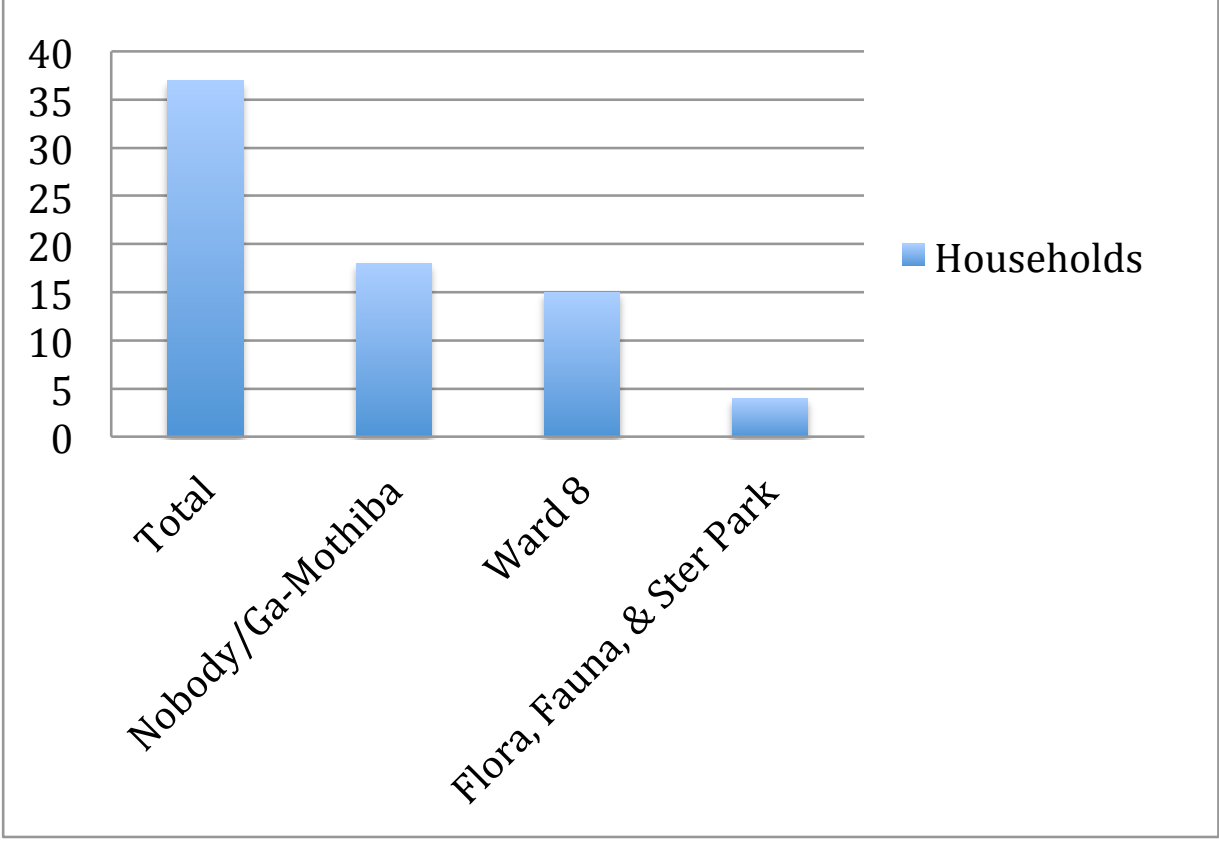

Figure 4-3: Livelihood activities

than one household member working. A secondary source of income is either from a social 
$\operatorname{grant}^{23}$ or business activity. Less than $20 \%$ of households consistently participate in agriculture or raising livestock, and more than $64 \%$ of households rely on wage labor in both the formal and informal sectors of the economy. As the number of livelihood activities increase, either by more household members joining the workforce or diversifying into other activities, the average household income also rises for between one and three livelihood activities. However, households with four activities have a notably lower total income (Figure 4-4). The majority of the "4 or more" activity households are in Nobody/Ga-Mothiba, which has more rural characteristics than the other two sites (Figure 4-1).

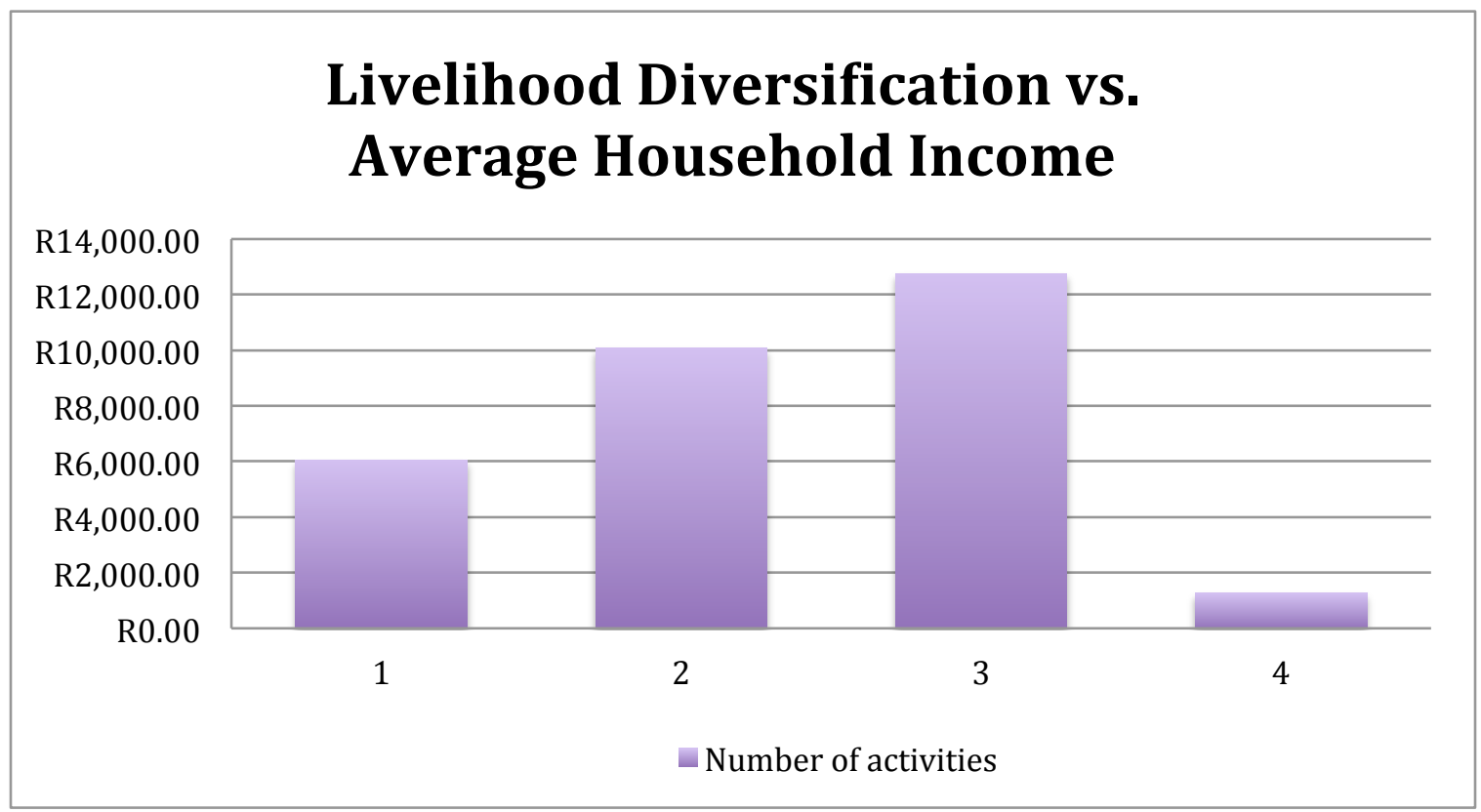

Figure 4-4: Livelihood Diversification and Household Income

In Nobody/Ga-Mothiba, $21 \%$ of households engage in three or more livelihood activities. Even though Flora, Fauna and Ster Park have the fewest number of households participating in multiple activities, those that do have relatively large monetary gains from their business activities. Households in the newly developing suburbs have multiple household members

\footnotetext{
${ }^{23}$ A social grant is a sum of money given to the household for support each month as part of South Africa's social safety net. There are typically two types of social grants: one for old age and one for children. Child grants are awarded per child. At the time of research in 2012, the grant was 240R (\$32) per month per child based upon the exchange rate at the time $(7.5$ rand $=\$ 1)$.
} 
working in addition to high revenue businesses, compared to those in Nobody/Ga-Mothiba, where activities are high but incomes are low (Figures 4-3 \& 4-4). This is just one example of the strong inequality that still exists within South Africa.

Even though those engaging in two or more activities are wage laborers, many also work in the informal economy. Wage earners in Nobody/Ga-Mothiba and Ward 8 are more likely to work in the informal sector than those in Flora, Fauna and Ster Park. While Flora, Fauna and Ster Park had a few households engaging in multiple livelihood activities, it is interesting to note that these households have an average of 1.9 household members as wage earners, whereas Nobody/Ga-Mothiba and Ward 8 only have around 1.0. With more individuals per household working in Flora, Fauna and Ster Park, average household incomes and expenditures are much higher. Nobody/Ga-Mothiba and Ward 8 also have larger percentages of those working in informal jobs than Flora, Fauna and Ster Park. The large diversification combined with participation in the informal economy illustrate individuals are generating income through different avenues in Nobody and Ward 8, than Flora, Fauna and Ster Park. While households in Flora, Fauna, and Ster Park primarily rely on wages and businesses to earn a living, Ga-Mothiba and Ward 8 are more reliant on wages, and government subsidies and informal activities to make ends meet.

Wage labor

The role of wage labor in peri-urban households as a key livelihood activity is substantial (Table 4-1). Similarly, work is also one of the primary draws of people to the city and peri-urban areas from rural villages or "homes". Focus Group 1 (2012 emphasis added) enforced this finding:

Enumerator: What is the importance of living close to town? 
Respondent 1: The main importance is to get a job quickly and pay less for transport to get to town.

Enumerator: What does town have that other areas do not have?

Respondent 1: We are interested in jobs.

Respondent 2: Yes, it's true that there are jobs in town.

Respondent 5: We are here because of jobs.

Respondent 3: Another reason is that Disteneng is very close to town, close to the factories and also close to the airport whereby we do things easily. We go job-hunting close to us without spending any dime because we just walk to town.

Access to wage labor and the job market is the most important survival activity for most households - though some have begun to realize how limited this opportunity may be. For example, one participant said, "It is very difficult [to find a job in Polokwane] because the population of unemployed people is way too higher than the capacity of factories around Polokwane" (Respondent 3, 2012; Focus Group 1, 2012). Others echoed the challenges of finding employment by describing their experiences. "People hire their brothers and sisters and only those they personally know. It's all about how much you are willing to pay to get a job. Other jobs are dependent on a database. So if you enlist late, then you will be hired last" (Respondent 41, 2012). This participant was very clear about the post-apartheid challenges of finding work and said, "There is nepotism in the workplace and there is still racism in other employers. They would tell you to go to your grandfather Mandela for a job" (ibid).

The high number of people in the informal sector of the economy, combined with the need for wages, is further complicated by high unemployment rates throughout the region and 
the consistent underemployment which many individuals face. It has been argued that this is a component of disciplining labor in South Africa's strongly unionized labor market and plays out in a variety of contexts including the increasing need for work to survive, yet unavailability of that same work. ${ }^{24}$

\begin{tabular}{|lcccc|}
\hline \multicolumn{4}{|c|}{ Number of Informal and Formal Wage Earners } \\
\hline & Total & $\begin{array}{c}\text { Nobody/ } \\
\text { Ga- } \\
\text { Mothiba }\end{array}$ & Ward 8 & $\begin{array}{c}\text { Flora, Fauna } \\
\text { and Ster Park }\end{array}$ \\
\hline Informal Wage Earners & 80 & 34 & 35 & 11 \\
\hline Formal Wage Earners & 113 & 22 & 25 & 66 \\
\hline Undetermined Wages Earners & 70 & 22 & 39 & 9 \\
\hline Total Employed & $\mathbf{2 6 3}$ & $\mathbf{7 8}$ & $\mathbf{9 9}$ & $\mathbf{8 6}$ \\
\hline $\begin{array}{l}\text { Number of households } \\
\text { represented }\end{array}$ & 225 & 75 & 104 & 46 \\
\hline
\end{tabular}

Table 4-1: Informal and Formal Wages

In order to address this contradiction, many individuals move to peri-urban areas to have more flexibility in accessing the labor market as well as to avoid high transport costs of commuting from villages to the city. As households seek to negotiate the challenges posed by accessing the labor market, they transform landscapes near the city into temporary housing and increase demand for government funding RDP houses. This growth and increase in peri-urban space is documented in Figure 4-2.

As previously pointed out by Rakodi (2002), the heterogeneity of urban places can reduce social networking abilities within a livelihoods structure. This is also the case in and around Polokwane. All of the participants living in Nobody/Ga-Mothiba and Ward 8 were black Africans, yet they came from different areas of Limpopo, spoke different languages, and some

\footnotetext{
${ }^{24}$ COSTAU is an example of the strength of unions as the largest union federation. COSATU is the Congress of South African Trade Unions and has 21 affiliate unions and over 1.8 million members, dominated by blue-collar and African membership (Marias 2012).
} 
were from different former bantustans. For example, former residents of both Venda and Lebowa were represented within the sample sites, each having different tribal histories and cultures. These differences were most apparent when they were asked questions about local culture as well as local land use patterns and values. One Participant $(84,2012)$ noted that he does not know his neighbors, while another said household members were on a first name only basis with most of the neighbors. The same person also stated, "If I want to put on my Tsonga clothes and my neighbors is going to put on his Venda clothes, then no one is going to encourage us with our culture. When we talk about culture, we talk about people who live more or less the same, so you need to go home and do your cultural activities. These sites each having different tribal things." He also told us, "We don't have cultural connections and I don’t know my neighbors. But at home I know all people who are next to my home..." (Respondent 84, 2012).

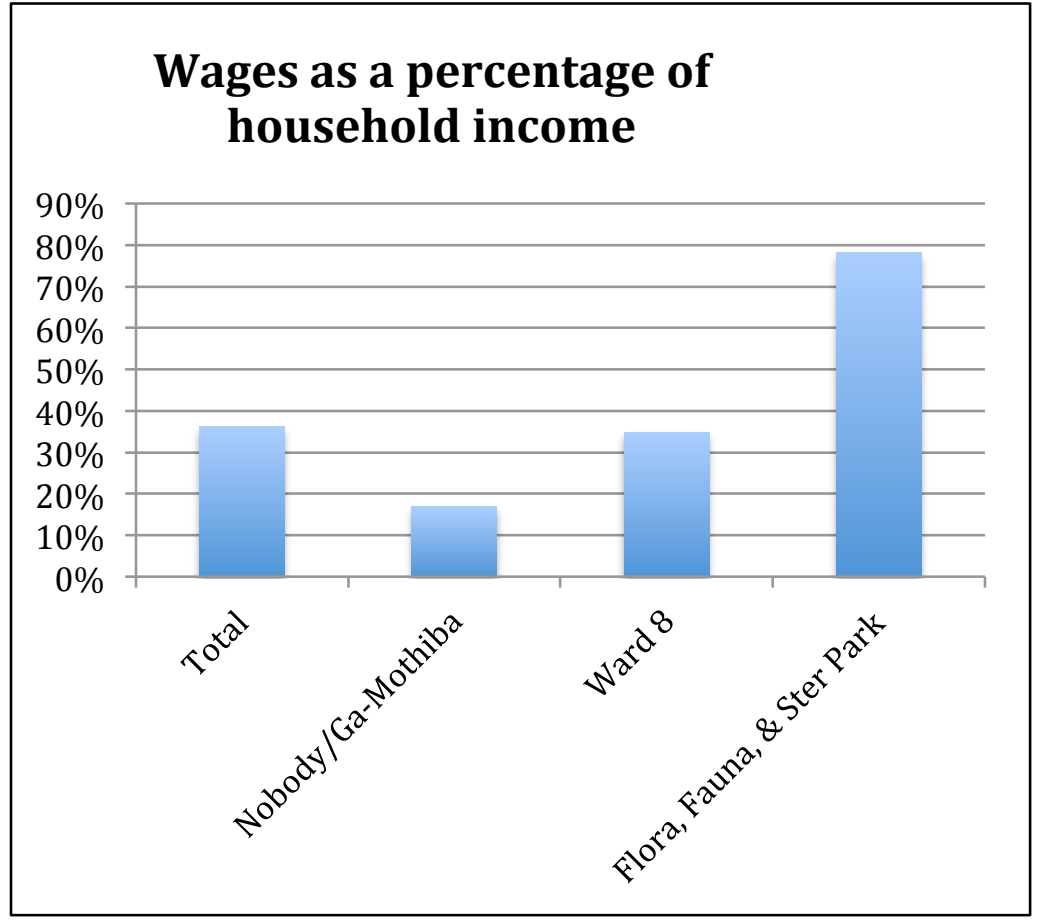

Figure 4-5: Wages and Household Income
Local social networks are limited by a lack of familiarity and cultural sameness within these heterogeneous areas and growing peri-urban spaces. For help finding employment, accessing communal labor or the pooling of resources as a livelihood activity, households in peri-urban spaces are more

limited. As these networks intimately link peri-urban residents to their culture and family, most indicated that they maintained ties with their rural villages (in the former bantustans) and some 
receive food or other products several times a year from family or friends. While this obtaining of goods is not a consistent component to their every day survival, it nevertheless represents one of the key networks people access to reduce some of the effects of poverty.

In the informal settlements, there can be a number of immigrants from outside of South Africa. The percentage of those living in informal settlements, such as Disteneng, that are migrants (legal or illegal) was not estimated because the issue is fraught with concerns regarding safety and limited access. During one of the focus groups, which was able to access residents living in an informal settlement, participants described their general distrust of Zimbabweans due to different cultural and religious practices, as well as language barriers. This distrust, compounded by higher crime rates in these informal areas, contributes to a breakdown in the sense of community and reduces the leverage and momentum informal communities are able to achieve when positioning or bargaining with local government. This further complicates a general lack of homogeneity or inclusive social networks and reduces the community's ability to organize and access additional resources from the municipality.

\section{Land Use Changes}

Land use changes in the three study sites (Figure 4-1 and Figure 4-2) show increases in peri-urban space since the end of apartheid. There has been significant growth in Ward 8 and Flora, Fauna, and Ster Park in the post-apartheid era. In addition to peri-urbanization, the landscape around peri-urban areas also fluctuates due to shifting and constantly changing landuses. In this sense, the areas around Polokwane have experienced both peri-urban growth and decline. In the particular case of Nobody/Ga-Mothiba, the changes in peri-urban land cover represents a shift in housing density as well as farming practices within the Tribal Authority Area. Land has remained under the control of the Tribal Authority through the transition to 
majority rule and many families have lived in this traditional community for more than thirty years. While the community has been established, its land use patterns are changing as both long time community members and newcomers seek access to wage labor in Polokwane. This is in contrast to Ward 8 expansion where new communities are being formed, albeit with less control over local land use practices.

Survey data reveals that $71 \%$ of households value land as very important to making a living, yet only $23 \%$ indicated that they considered whether or not they'd have land to farm before relocating. Most households (77\%) indicated that access to land was most important for housing, and $43 \%$ stated that they ONLY considered housing the main reason for moving. While full-scale farming is not of serious concern to most of the participants, $55 \%$ said they were concerned about having enough land for a small garden. As individuals negotiate the challenges of their every day lives, local land use patterns reflect the processes of obtaining housing and living in proximity to town. Housing is one of the primary reasons households move into periurban areas. One respondent noted, "The only land we use now is our yards" (Respondent 84, 2012). But by this she didn't necessarily mean for gardens, but more for everyday living. Outside areas are used to hang laundry, talking with friends and neighbors, or even for running a small business.

Those who place a high value on land as a livelihood resource do not produce food on the land. Where households most often farm or produce food is in the rural villages from where they moved. One household (Respondent 102, 2012) relies on older family members and the extended family to produce food from their land in Moletjie. This particular household relies on the land in the rural village to supply both their household and the families at home with vegetables several times a year. They choose to live near the city for better educational opportunities and receive 
money from a social grant to pay local bills (ibid). In this instance, the co-production of periurban space through land use and livelihoods becomes clearer.

Peri-urban space is produced when the family only has enough to eat through accessing rural kinship networks and at the same time needs to rely on government subsidies to make ends meet. Living close to the city improves their access to government funding as well as education opportunities for the children. These households negotiate their place between the rural and urban by relying on livelihood activities in both and continuing to produce demand for periurban housing in the process. Other households use similar techniques of keeping livestock at other locations (usually rural villages or home) to supplement their income. It should also be noted here that most households which raise livestock do so at a loss - meaning they do not actually make money off of their animals and in fact will often use other sources of income to maintain livestock holdings.

As the municipality becomes more involved in the local development process, especially in terms of continuing to expand the RDP townships and the Spatial Development Areas, they have also become more concerned with land use planning. Informal settlements such as Mashinini and parts of Disteneng have been dismembered and their former inhabitants relocated. ${ }^{25}$ Households that used to live in Mashinini had more land area with which they could farm until they were relocated in the mid-late 2000s (Respondents 92, 102, and 113, 2012). One former resident noted that in Mashinini they "self-distributed land", meaning there was no formal authority (traditional or municipal) over the area. Community members decided plot locations and sizes, as well as allocated farmland to themselves and each other. They also farmed on this

\footnotetext{
${ }^{25}$ Mashinini and Disteneng are informal settlements on the outskirts of Polokwane. Mashinini was torn down in 2007, and Disteneng currently occupies the former township of New Pietersburg. Disteneng has undergone several reductions over the years to try and keep numbers lower and avoid completely overwhelming existing service provision (mainly water).
} 
land and paid no rent or fees for services. Only water was available at the time until they were relocated between 2005 and 2007. Unlike in the RDP townships where the municipality discourages farming, they were free to use the land as they liked in the informal context.

The Co-Production of Peri-Urban Space

Most of the livelihood activities in peri-urban areas are more typical of urban livelihood systems and are based on wages, business, and access to government services such as subsidized housing. Especially in Nobody/Ga-Mothiba and Ward 8 (which are more peri-urban than Flora, Fauna, and Ster Park), households also rely heavily on access to informal market activities through piece meal work and informal business activities like hawking. In order to continue to be able to access the markets for these activities, households feel that it is absolutely necessary to be "close to town", meaning Polokwane, and it is essential for them to procure employment and maintain access to cheaper goods.

Some households communicated a general decrease of cultural activity in the peri-urban areas from activities in rural villages, and view their land in peri-urban zones as a place to lay their head and find work, rather than live their life. Many households still feel a deeper cultural connection to their rural village and consider it home. As one respondent told me, "If someone dies here that person is going to be buried at original home" (Respondent 84, 2012, emphasis added). However, at the same time most households have diversified income strategies and rely on more than one source of income to make ends meet, which is more of a rural coping method to structural change (economic, social, or cultural). As previously mentioned, most households do not engage in agricultural activities and those that do often rely on land elsewhere for 
productivity. This results in the co-production of peri-urban space as a combination of rural livelihood patterns and urban land uses.

One urban resource residents' use to improve livelihoods is the transportation network. Road networks provide quicker and more reliable access to the urban center. While roads in the periurban areas are generally in poor condition and most are not paved, residents do gain cheaper transport costs to town. The ability to lower transport costs or eliminate them entirely is one of the most highly cited reasons for moving to the peri-urban interface (Respondents 53, 67, 70, and Focus Group 1, 2012). This reduces households' overall costs associated with many livelihood activities including both formal and informal wage labor, business activities, and markets for goods and services. Residents of peri-urban spaces are most concerned with water, sanitation, housing and roads in local areas to improve their quality of life (ibid).

While the peri-urban interface is co-produced by material realities and discursive formations, through local livelihoods and land use practices, all of these processes, which affect local decision-making are not necessarily local. Rather individuals and households negotiate changes and challenges across a variety of scales. While negotiating the regional challenges of overcoming distance and transport costs to obtain work, they also encounter unemployment and underemployment stemming from the international labor regime and neo-liberal economic policies at both the international an national scales. Unemployment is a major concern in South Africa due to what J. Smith (2014) has argued are processes of deproletarianization - where individuals become unable to work or sell their labor as a commodity. Similarly, neo-liberal economic policies have restructured the South African economy and enabled corporations to choose laborers on a global rather than a national or regional scale (see also Marias 2011). 
Politics at the national and regional scale also impact labor opportunities as well as access to government resources and participation in local government processes. As the ANC moves into it's $21^{\text {st }}$ year as a majority party representing South Africans, it has failed to fulfill many of its original promises and fallen vastly short of both its RDP and GEAR goals (Bond 2005, Marias 2011 $)^{26}$. Individuals at the local level must still work within these power structures and regimes in order to access the resources they need. From building more RDP housing to properly funding schools, corruption in local government has also placed significant burdens on households as they negotiate. The tender system currently means that the government is spending large sums of money to have public services installed. In some recorded cases, companies fail to complete their contract and make off with the money paid to them for the service (Respondent $9909,2012)$. Similarly, companies receiving tenders have completed work that is of poor quality (ibid). Local government is increasingly under pressure to fill the access gap as Hart (2002:7) explains, "[1]ocal counsilors and bureaucrats have been called upon to confront massive redistribute pressures with minimal resources. Simultaneously they have been assigned major responsibility for securing the conditions of accumulation...".

Furthermore, Limpopo contains three former bantustans, which were intentionally marginalized during the apartheid era (Bond 2005, Marais 2011, Legassick and Wolpe 1976, Lemon 1976). Most of the individuals moving to Polokwane come from villages within the former bantustans. While households must negotiate their own survival on a daily basis, they are challenged by a variety of processes occurring across scales. Households have also been forcibly

\footnotetext{
${ }^{26}$ Reconstruction and Development Programme (RDP) was the platform economic policy of the African National Congress (ANC) in the 1993 elections. The document was created to right many of the wrongs and undo the apartheid system. It was significantly underfunded and abandoned in Thabo Mbeki's first months as President (following Nelson Mandela). The Growth Employment and Redistribution (GEAR) macro-economic policy followed the RDP with a much larger neo-liberal agenda - thought it also failed to achieve expected levels of economic growth or redistribution.
} 
moved from one place to another by local government to limit the growth of informal settlement (Respondent 61, Respondent 67, Respondent 94, Respondent 96, 2012). As one relocated resident voiced, "The municipality hosted several meetings telling us to move back to our original homes but eventually gave us stands at Extension 71 after realizing how stubborn we were" (Respondent 61, 2012). Local government is not necessarily a villain in this process. They recognized both the need and the challenges many households face in the area and do their best to provide services such as water and electricity (Respondent 9918, 2012). All of these processes: desegregation, government assistance, access to services, including better schools (mediated by institutions), wage labor markets, business opportunities, transport networks, and a continued reliance on rural networks, all work together to coproduce peri-urban space as individuals negotiate these and many other challenges to their everyday lives.

\section{Conclusion}

The peri-urban interface is a manifestation of the co-production of livelihoods and land uses in post-apartheid South Africa. The case study sites in Polokwane provide evidence that increasing peri-urban growth is a material manifestation of the processes producing local livelihoods and land use changes. While persistent inequality exists, individuals in peri-urban spaces have diversified their livelihood activities, not only in securing income sources (wages, businesses, and social grants) but also by gaining access to urban housing opportunities (RDP houses), more extensive and inexpensive transportation networks, as well as labor and commodity markets. Migration to peri-urban areas is a growing trend for negotiating day-to-day survival in this region of South Africa. The paths that individuals take including wage labor, informal economic activity, participation in multiple livelihood activities, and obtaining government resources (subsidized housing and social grants) are more readily available in the 
peri-urban interface. The manners in which individuals negotiate these challenges produce periurban space with relatively dense populations, little agricultural or livestock production, and an increasing reliance on the monetization of services (specifically water and electricity) ${ }^{27}$. This continues to ensure that residents will compete within a surplus labor pool.

As peri-urban spaces expand, increasing pressure is placed on local governments to provide services for those living in these communities. In parallel, the local municipality has dedicated specific areas to be developed for low and middle income housing growth. Local government is largely responsible for designating land use, as illustrated in land use change maps. Ultimately, the areas just outside of Polokwane have undergone rapid residential growth between 1990 and 2009, and the people living there have responded with changes in both land use and livelihoods to produce the peri-urban interface. Many migrants view the economic incentives to move closer to the city as outweighing the negative aspects of living in the new RDP townships or informal settlements. But many also feel as though they have no choice. While the peri-urban interface may be a post apartheid-space, it is certainly not a post-poverty space.

\footnotetext{
${ }^{27}$ In some instances, electricity credits may be made available to the poorest households and there are some communities, Ga-Mothiba for example, where water is free.
} 


\section{Chapter 5: CONCLUSiON}

\section{Challenges and Positionality}

This dissertation highlighted the social processes contributing to peri-urban growth and continued uneven development in Polokwane, South Africa in the post-apartheid era. The results of this research are extremely fruitful, yet much remains to be done in order to improve the lived experiences of South Africans in the peri-urban interface. As the primary investigator of this project, I, and my research team, experienced several challenges including skepticism from local populations, accessing gatekeepers, spectral and spatial resolution issues in the remote sensing analysis, and the desired accuracy of change images while undertaking this work. Local populations can feel over-researched because they are well connected to the global society. The research team also heard questions such as 'who will really benefit from this'? I was as straightforward and honest, as possible, and told them no immediate benefits were known. Research participants in the quantitative survey each received a $1 \mathrm{~kg}$ bag of powdered laundry soap (which costs anywhere from 15-25 Rand, or \$2-\$3) ${ }^{28}$. Most households appreciated this gift, a good brand of soap, an expense they cannot always afford.

Challenges with the data collection included minor translation issues, consistency issues, and expanding on responses to the qualitative questions. This led me to realize that I was asking the wrong questions, and to compensate I re-evaluated the questions, reviewed the data collected, and drafted different questions. Many who participated in the original quantitative interview did not want to participate in the qualitative portion of the study for reason's I was never fully able to identify. I struggled to get participants in Nobody/Ga-Mothiba, under tribal authority

\footnotetext{
${ }^{28}$ South African Rand to USD conversion rates are based on the average exchange rate (7.5 Rand = $\$ 1$ ) at the time of data collection, 2012.
} 
management, to participate in the qualitative interviews. The fact that two of my enumerators belonged to the community got me in the door for the quantitative surveys, though it seemed the opposite was true for the qualitative interviews. I obtained a few more from Nobody/Ga-Mothiba with the help of my other two enumerators (non-community members), but it took longer than originally anticipated.

In addition to these challenges, classified change images need accuracy improvement. Therefore, an important research avenue is refining the remote sensing classification technique and applying it to peri-urban growth. Spectrally, peri-urban classes (land covers such as: tin roofs and sheet metal) have the same spectral signature as very bare earth and dry riverbeds. I manually digitized and re-coded parts of the images to remove some of this confusion.

\section{Summary of Research Results}

South Africa has not eradicated the legacies of apartheid. Despite 20 years of democracy, growing economic inequality still affects the lived experiences of South Africans. South African President Jacob Zuma's state of the nation address in February 2015 recommitted the national government to land reform and redistribution. The continued concentration of agricultural land holdings in South Africa, provides further illustration that changes to government structure and more equal political representation, have not yet resulted in a more equal wealth distribution. This research illustrates that rather than reducing poverty over the past 20 years, South Africa has simply rescaled it, or moved it, from bantustans to peri-urban areas. This dissertation argues that the production of peri-urban space is the result of the confluence of three processes including: changing labor relations, continued uneven development, and the co-production of land use and livelihoods. By engaging the theoretical underpinnings of each process, this 
research seeks to provide a counter narrative to the changes occurring in post-apartheid South Africa.

\section{Deproletarianization}

Changing labor relations in Polokwane revolve around the increasing need to find work for wages, coupled with the processes of deproletarianization. Deproletarianization means that labor is no longer a commodity and therefore laborers are unable to sell their labor as they choose. The first chapter argued that through deproletarianization capital has found a new method of disciplining labor and creating the optimal conditions for maintaining a large labor pool similar to those it had during apartheid in the bantustans. In this example, piecemeal work or work in the informal sector comprises important supplemental opportunity to those seeking jobs. The legacies of apartheid labor restrictions and land rights, including color bars and the inability to own land, have continued to limit black South African's access to other reproductive means.

The double movement of being unable to avoid the labor market, despite alarmingly high unemployment, means that labor in Polokwane is not even a commodity. This contribution to the production of peri-urban space means that living next to the city is a vital requirement for making ends meet. Households with permanent or stable employment are able to afford better housing in the newer middle and high-income suburbs or the commute from more rural areas. But because labor is so plentiful and jobs are so scarce, anyone not living close enough to walk to the city is effectively missing out on any potential opportunities for work and improving their life. 


\section{Uneven Development}

In addition to changing labor relations in Polokwane, the production of space under the capitalist mode of production shifted after apartheid-ended. While the legacies of the race-based capitalism of apartheid have ended, capitalism replaced the former bantustans with peri-urban spaces as cheap and well-disciplined sources of labor. While apartheid era labor and land ownership restrictions no longer apply, households in the peri-urban interface are much worse off than those in the suburbs, only the suburbs are no longer limited to white households. Households in peri-urban spaces rely more on non-productive forms of household income (social grants, gifts, and pension) than those in the suburbs - which is a scathing indictment of postapartheid economic reform and overall policy failure.

\section{Co-production}

The coproduction of land use and livelihoods enables us to tease apart and explore the variety of social processes that contribute to the continued growth of peri-urban space. While the first two chapters highlighted some of the macro level social processes contributing to lived experiences within South Africa, the coproduction thesis enables us to consider all of the processes embedded within the coproduction of peri-urban space. Deproletarianization is one example of the changing social relations contributing to peri-urban growth. To fully understand why peri-urban space is growing rapidly in the post-apartheid era, we must explore past growth trends, current land use practices and values, as well as current livelihood practices.

Local land use practices focus more on obtaining shelter and supporting access to the labor market. Households rely on proximity to the city and shelter near the city for access to urban transportation networks, municipality services, and affordable housing so that they can 
always, easily, and cheaply be looking for work. At the same time, household livelihoods in these areas are heavily diversified with about $30 \%$ of households participating in more than three activities. Some of the activities households use to make ends meet on a monthly basis are social grants, wage labor and small businesses (in both the formal and informal sectors of the economy) as well as limited agriculture and livestock production.

\section{Future Research}

From this research, I have identified several pathways for classifying and understanding the production of peri-urban space. In the immediate future, I will refine my classification techniques for the satellite imagery. Some of the avenues I want to explore are: applying a texture filter, masking peri-urban versus non-peri urban and classifying the data separately. Along similar lines, using more high-resolution imagery may improve classification accuracy as well as potential data fusion techniques. I am able to test this on the existing GEOEYE imagery I have from 2009 within the near future. Since I already have the aerial photography used for accuracy assessment georeferenced, this research could be completed with relative ease and little to no funding beyond access to the software.

I have not fully analyzed the data collected in South Africa, and I intend to explore the following themes in future analysis: local governance and planning policy, a gendered approach to understanding livelihoods in peri-urban spaces, and intra-household variability. The issues surrounding not only gendered livelihoods but gendered migration into and out of peri-urban spaces offers a new research frontier to be explored at both the local as well as regional and global contexts. Finally, regional migration and urban land teleconnections are research endeavors that aid in a deeper understanding of uneven development in South Africa. 


\section{REFERENCES}

1, Focus Group, interview by Lesedi Mphela Kanyane, Johnny Monyebodu, Corey Smith Jennifer Smith.

Focus Group 1, Edited by Jennifer Smith, translated by Johnny Monyebodu. (04 24, 2012): 1-14.

102, Respondent, interview by Lesedi Mphela Kanyane. Edited by Jennifer Smith, translated by Augustine Mothiba. (05 01, 2012).

113, Respondent, interview by Lesedi Mphela Kanyane.Edited by Jennifer Smith, translated by Augustine Mothiba. (05 01, 2012).

41, Respondent, interview by Jennifer Smith.Translated by Johnny Monyebodu. (April 18, 2012).

47, Respondent, interview by Jennifer L. Smith.Translated by Johnny Monyebodu. (April 12, 2012).

49, Respondent, interview by Jennifer L. Smith.Translated by Lesedi Mphela Kanyane. (April 17, 2012).

53, Respondent, interview by Jennifer L. Smith.Translated by Lesedi Mphela Kanyane. (April 17, 2012).

61, Respondent, interview by Jennifer L. Smith.Translated by Johnny Monyebodu. (April 18, 2012).

62, Respondent, interview by Jennifer Smith.Translated by Johnny Monyebodu. (April 18, 2012).

67, Respondent, interview by Lesedi Mphela Kanyane.Translated by Lesedi Mphela Kanyane. (April 23, 2012).

70, Respondent, interview by Lesedi Mphela Kanyane Jennifer Smith.Translated by Lesedi Mphela Kanyane. $(04$ 23, 2012).

78, Respondent, interview by Jennifer L. Smith.Translated by Johnny Monyebodu. (April 18, 2012).

84, Respondent, interview by Alexia Mothiba.Translated by Johnny Monyebodu. (04 18, 2012).

92, Respondent, interview by Lesedi Mphela Kanyane.Translated by Augustine Mothiba. $(04$ 17, 2012).

94, Respondent, interview by Lesedi Mphela Kanyane.Edited by Jennifer Smith, translated by Augustine Mothiba. (04 17, 2012).

96, Respondent, interview by Lesedi Mphela Kanyane.Edited by Jennifer Smith, translated by Lesedi Mphela Kanyane. $(04$ 23, 2012).

9903, Respondent, interview by Lesedi Mphela Kanyane.Translated by Augustine Mothiba. (04 10, 2012).

9905, Respondent, interview by Johnny Monyebodu Jennifer Smith. $(04$ 12, 2012).

9909, Respondent, interview by Jennifer Smith.Edited by Jennifer Smith. (04 30, 2012). 
9911, Respondent, interview by Johnny Monyebodu Jennifer Smith. (06 21, 2012).

9918, Respondent, interview by Jennifer Smith.Edited by Jennifer Smith. $(07$ 09, 2012).

African Development Bank. African Economic Outlook. Youth Employment, OECD Development Center \& UN Development Programme, Un Development Programme, 2014.

African National Congress. "ANC's Reconstruction \& Development Programme." University of Pennsy/vania African Studies Center. University of Pennsylvania. 06 07, 1994. http://www.africa.upenn.edu/Govern_Political/ANC_Recon.html (accessed 11 25, 2013).

-. "ANC's Reconstruction and Development Programme." University of Pennslyvania - African Studies Center. Edited by Ali B. ali-Dinar. African Studies Center. June 6, 1994. http://www.africa.upenn.edu/Govern_Political/ANC_Recon.html (accessed November 25, 2013).

Alphan, H. "Land-use change and urbanization of Adana, Turkey." Land degradation \& development 14, no. 6 (2003): 575-586.

Altman, Miriam. "Low Wage Work in South Africa." IZA/World Bank Conference on Employment and Development. Berlin, 2006.

Armstrong, W, and T McGee. Theatres of accumulation: Studies in Asian and Latin American Urbanization. New York: Methuen, 1985.

Banerjee, Abhijit, Sebastian Galian, Jim Levinsohn, Zoe McLaren, and Ingrid Woolard. "Why has unemploymen risen in the New South Africa?" Economics of Transition (Blackwell Publishing) 16, no. 4 (2008): 715-740.

Barchiesi, Franco. "Wage Labor, Precarious Employment, and Social Inclusion in the Making of South Africa's Post-apartheid Transition." African Studies Review (Cambridge University Press) 51, no. 2 (2008): 119-142.

Bhorat, Haroon. "Labour Market Challenges in the Post-Apartheid South Africa." South African Journal of Economics 73, no. 5 (2004): 940-977.

Bhorat, Haroon, and Joe Hodge. "Decomposing Shifts in Labour Demand in South Africa." South African Journal of Economics 67, no. 3 (1999): 155-168.

Bhorat, Haroon, Paul Lundall, and Sandrine Rospabe. "International Labour Organization ." ILO Publications. International Labour Organization. 2002. http://www.oit.org/wcmsp5/groups/public/--ed_emp/documents/publication/wcms_142363.pdf (accessed 02 12, 2014).

Bond, Patrick. Elite Transition: From Apartheid to Neoliberalism in South Africa. 2nd. University of KwaZulu-Natal Press, 2005. 
Brass, Tom. Labour Regime Change in the Twenty-First Century. Boston, MA: Brill, 2011.

Brass, Tom. "Primitive Accumulation, Capitalist Development and Socialist Transition: Still Waiting for Godot?" Journal of Contemporary Asia (Routledge) 41, no. 1 (2011): 1-24.

Brass, Tom. "Some Observations on Unfree Labour, Capitalist Restructuring, and Deproletarianization." International Review of Social History 39 (1994): 255-275.

Bundy, Colin. The Rise and Fall of the South African Peasantry. 2nd. London: James Currey, 1988.

Campbell, David J, David P Lusch, Thomas A Smucker, and Edna E Wangui. "Multiple methods in the study of driving forces of land use and land cover change: a case study of SE Kajiado District, Kenya." Human Ecology 33, no. 6 (2005): 763-794.

Carr, Edward, and Brent McCusker. "The co-production of land use and livelihoods change: Implications for development interventions." Geoforum 40, no. 4 (2009): 568-579.

Carr, Edward. "Men's Crops and Women's Crops: The Importance of Gender to the Understanding of Agricultural and Development Outcomes in Ghana's Central Region." World Development 36, no. 5 (May 2008): 900-915.

Castree, Noel. "Marxism and the Production of Nature." Capital \& Class 24, no. 72 (2000): 5-36.

Castree, Noel. "Neoliberalising nature: processes, effects and evaluations." Environment and planning $A$ 40, no. 01 (2008): 153

Castree, Noel, and Bruce Braun. Social Nature. Malden, MA: Blackwell, 2001.

Chambers, Robert, and Conway, Gordon R. "Sustainable rural livelihoods: practical concepts for the 21st century." IDS Discussion Paper, no. 296 (12 1991).

Christopher, A.J. "Urban Segregation in Post-Apartheid South Africa." Urban Studies 38, no. 3 (2001): 449-466.

City Press. news 24: breaking news first. 12 05, 2011. http://www.news24.com/Archives/City-Press/FiveLimpopo-departments-under-administration-20150429 (accessed 07 22, 2015).

De Haan , Leo, and Annelies Zoomers. "Development geography at the crossroads of livelihood and globalisation." Tijdschrift voor economische en sociale geografie 94, no. 3 (2003): 350-362.

De Haan, Leo J. "The Livelihood Approach: A Critical Exploration." Erdkunde 66, no. 4 (Oct-Dec 2012): 345-357.

Dewan, Ashraf M., and Yasushi Yamaguchi. "Using remote sensing and GIS to detect and monitor land use and land cover change in Dhaka Metropolitan of Bangladesh during 1960-2005." Environmental Monitoring \& Assessment (Springer) 150 (2009): 237-249. 
Donaldson, Donnie, and Nico Kotze. "Residential Desegregation Dynamics in the South African City of Polokwane (Pietersburg)." Tijdschrift voor Economische en Sociale Geografie (Blackwell) 97, no. 5 (2006): 567-582.

Donaldson, Ronnie, and Nico Kotze. "Residential Desegregation Dynamics in the South African City of Polokwane (Pietersburg)." Tijdschrift voor economische en sociale geografie (Blackwell Publishing) 97, no. 5 (2006): 567-582.

Ellis, Frank. Rural livelihoods and diversity in developing countries. Oxford: Oxford University Press, 2000.

Feinstein, Charles. Economic History of South Africa. New York: Cambridge University Press, 2005.

Fine, Ben, and Zavareh Rustomjee. The Political Economy of South Africa. Boulder, CO: Westview Press, 1996.

Fisher, Monica, Moushumi Chaudhury, and Brent McCusker. "Do forests help rural households adapt to climate variability? Evidence from Southern Malawi." World Development 38, no. 9 (2010): 1241-1250.

Flanagan, Louise. Why Limpopo lost out on R1.3bn. IOL NEWS. February 26, 2014. http://www.iol.co.za/news/politics/why-limpopo-lost-out-on-r1-3bn-1.1653075 (accessed March 12, 2014).

Geist, Helmut J., and Eric F. Lambin. "Proximate Causes and Underlying Driving Forces of Tropical Deforestation." BioScience 52, no. 2 (February 2002): 143-150.

Grabbatin, Brian Chalres. "'I Still Have the Old Tradition": The co-production of sweetgrass basketry and coastal development." Geoforum 42, no. 6 (2011): 638-649.

Grabbatin, Brian Charles. "Stweegrass basketry: the political ecology of an African American art in the South Carolina Lowcountry." Master's Thesis. Chalreston, SC, 2008.

Greenberg, Stephen John. "Land reform, space and power in Makhado municipality, Limpopo, South Africa." PhD Dissertation. pdf. Prod. University of Sussex. Sussex, July 2011.

Grobler, Fienie. "Service-delivery protests a 'warning sign' for govt." Mail \& Guardian. Main \& Guardian, 07 20, 2009. 1-3.

Hart, Gillian. Disabling Globalization: Places of Power in Post-Apartheid South Africa. Berkeley, CA: University of California Press, 2002.

Harvey, David. Justice, Nature and the Geography of Difference. Malden, MA: Blackwell Publishing, 1996.

Harvey, David. "On the deep relevence of a certain footnote in Marx's Capital." Human Geography 1 (2009): 226-231. 
-. Spaces of Global Capitalism: Towards a Theory of Uneven Geographical Development. London: Verso, 2006.

Harvey, David. "The Geopolitics of Capitalism." In Social Relations and Spatial Structures, by Derek Gregory and John Urry. London: Macmillian, 1985.

Hendricks, Bob. Urban Livelihoods, Institutions and Inclusive Governance in Nairobi: 'Spaces' and their Impacts on Quality of Life, Influence and Political Rights. Amsterdam University Press, 2010.

Hendricks, Fred T. The Pillars of Apartheid: land tenure, rural planning and the cheiftaincy. illustrated. Vol. 32. Academiae Ubsaliensis, 1990.

Jensen, John R, and Dave C Cowen. "Remote sensing of urban/suburban infrastructure and socioeconomic attributes." Photogrammetric engineering and remote sensing 65 (1999): 611-622.

King, Brian $\mathrm{H}$, and Brent McCusker. "Environment and development in the former South African bantustans." The Geographical Journal 173, no. 1 (2007): 6-12.

King, Brian. "Spatializsing livelihoods: resource access and livelihood spaces in South Africa." Transactions of the Institute of British Geographers 36, no. 2 (2011): 297-313.

Kingdon, Geeta, and John Knight. "Are Searching and Non-searching Unemployment Distinct States when Unemployment is High?" Centre for the Study of African Economies. Centre for the Study of African Economies. April 2000. http://www.csae.ox.ac.uk/workingpapers/pdfs/20-02text.pdf (accessed 2 12, 2014).

Kingdon, Geeta, and John Knight. "Race and the Incidence of Unemployment in South Africa." Review of Development Economics 8, no. 2 (2004): 198-222.

-. "Unemployment and wages in South Africa: a spatial approach." Center for the Study of African Economics. 4 1, 1999. http://213.154.74.164/invenio/record/17442/files/kingdon.pdf (accessed 02 12, 2014).

Kingdon, Geeta, and John Knight. "Unemployment in South Africa, 1995-2003: Causes, Problems, and Policies." Journal of African Economics 16, no. 5 (2007): 813-848.

Kingdon, Geeta, and John Knight. "What have we learnt about unemployment from microdatasets in South Africa?" Social Dynamics 27, no. 1 (2001): 79-95.

Knoetze, Daneel. "26 held after Malmesbury clashes." iol news. Malmesbury, Western Cape: iol news, 06 07, 2014.

Koti, Francis, and Daniel Weiner. "(Re) Defining Peri-Urban Residential Space Using Participatory GIS in Kenya." The Electronic Journal of Information Systems in Developing Countries 25, no. 8 (2006): 1-12. 
Lambin, E.F., and H.J. Geist. Global land-use and land-cover change: what have learned so far? Working Paper, African Studies Center, Boston University, Boston University, 2001.

Lambin, E.F., et al. "The Causes of Land-Use and Land-Cover Change: Moving Beyond the Myths." Global Environmental Change 11, no. 4 (2001): 261-269.

Legassick, Martin, and Harold Wolpe. "The bantustans and capital accumulation in South Africa." Review of African Political Economy 3, no. 7 (1976): 87-107.

Lemon, Anthony. Apartheid: a geography of separation. Farnborough: Saxon House, 1976.

Lo, C. P. "Application of Landsat TM data for quality of life assessment in an urban environment." Computers, Environment and Urban Systems 21, no. 3 (1997): 259-276.

Lopez, Erna, Gerardo Bocco, Manuel Mendoza, and Emilio Duhau. "Predicting land-cover and land-use change in the urban fringe: a case in Morelia city, Mexico." Landscape and urban planning 55, no. 4 (2001): 271-285.

Mabin, Alan, and Dan Smit. "Reconstructing South Africa's Cities? The making of urban planning 19002000." Planning Perspectives 12 (1997): 193-223.

Maharaj, Brij, and Sagie Narsiah. "From Apartheid apologism to post-apartheid neo-liberalism: paradigm shifts in South African Urban Geography." South African Geographical Journal 84, no. 1 (2002): 88-97.

Mandela, Nelson. Long Walk to Freedom: Autobiography of Nelson Mandela. Boston, MA: Little, Brown and Co., 1994.

Marais, Hein. South Africa Pushed to the Limit: The Political Economy of Change. New York, NY: Zed Books Ltd, 2011.

Marceau, Danielle J, Luc Guindon, Mireille Bruel, and Claude Marois. "Building Temporal Topology in a GIS Database to Study the Land-Use Change in a Rural-Urban Environment." Professional Geographer (Blackwell Publishing) 53, no. 4 (2001): 546-558.

Marx, Karl. Capital: A Critique of Political Economy. 8th Edition. Edited by Frederick Engles. Vol. 1. 3 vols. New York, NY: International Publishers Co. Inc., 1977.

Maylam, Paul. "Explaining the Apartheid City: 20 years of South African Urban Historiography." Journal of Southern African Studies 21, no. 1 (1995): 19-38.

Mbiba, Beacon, and Marie Huchzermeyer. "Contentious development: peri-urban studies in sub-Saharan Africa." Progress in Development Studies (Sage) 2, no. 2 (2002): 113-131.

McCusker, Brent. "Land use and cover change as an indicator of tranformation on recently redistributed farms in Limpopo Province, South Africa." Human Ecology 32, no. 1 (2004): 49-75. 
McCusker, Brent. "The political economy of nature." Human Geography 6, no. 3 (2013).

McCusker, Brent, and Daniel Weiner. "GIS representations of nature, political ecology, and the study of land use and land cover change in South Africa." In Political Ecology: An Integrative Approach to Geography and Environment-Development Studies, by KS Zimmerer and TJ Bassett, 201-218. 2003.

McCusker, Brent, and Edward Carr. "The co-production of livelihoods and land use change: Case studies from South Africa and Ghana." Geoforum 37, no. 5 (2006): 790-804.

McCusker, Brent, and Marubini Ramudzuli. "Apartheid spatial engineering and land use change in Mankweng, South Africa: 1963-2001." The Geographical Journal 173, no. 1 (2007): 56-74.

McCusker, Brent, Paul J.M. O'Keefe, Phil O'Keefe, and Geoff O'Brien. "Peasants, Pastorlaists and Proletarians: Joining the Debate on Trajectories of Agrarian Change, Livelihoods and Land Use." Human Geography (Institute for Human Geography) 6, no. 3 (2013): 3-11.

McCusker, Brent, William G Moseley, and Maano Ramutsindela. Land Reform in South Africa: An uneven transformation. Denver, CO: Rowan Littlefield, forthcoming.

Meikle, Sheilah. "The urban context and poor people." In Urban Livelihoods: A people centered approach to reducing poverty, by Carole with Tony Lloyd-Jones Rakodi, 37-51. New York, NY: Earthscan, 2002.

Moll, Terrance. "Did the Apartheid Economy Fail?" Journal of South African Studies 17, no. 2 (1991): 271291.

Muller, C, and J Esselar. "Documenting the informalisation fo working South Africa: Evidence from national household surveys, 1997-2001." Journal of Interdisciplinary Economics 15 (2004): 229249.

Municipal Demarcation Board. South Africa Administrative Boundaries. Edited by rmclaughlin_esriza. Prod. Municipal Demarcation Board. Pretoria, January 10, 2014.

Murray, Warwick E, and John D Overton. "Neoliberalism is dead, long live neoliberialism? Neostructuralism and the international aid regime of the 2000s." Progress in Development Studies 11, no. 4 (2011): 307-319.

Narsiah, Sagie. "Neoliberalism and privatisation in South Africa." GeoJournal 57 (2002): 3-13.

Oberhauser, Ann M, and Amy Pratt. "Women's collective economic strategies and political transformation in rural South Africa." Gender, Place \& Culture 11, no. 2 (2004): 209-228.

Oberhauser, Ann M, Jennifer L Mandel, and Holly M Hapke. "Gendered livelihoods in diverse global contexts: an introduction." Gender, Place \& Culture 11, no. 2 (2004): 205-208.

Ollman, Bertell. Dance of the Dialectic: Steps in Marx's Method. Urbana, IL: University of Illinois, 2003. 
Olson, J.M., S Misana, M. Mbonile, and S Mugisha. "A research framework to identify the root causes of land use change leading to land degradation and changing biodiversity." Land Use Change, Impacts and Dynamics (LUCID) Project Working Paper. Nairobi, Kenya: International Livestock Research Institute, 2004.

Onishi, Norimitsu. "World News: ANC posts strong lead in balloting in S.Africa, Zuma's scandals have slight effect." The Boston Globe. New York Times. 05 09, 2014. http://www.bostonglobe.com/news/world/2014/05/08/preliminary-results-show-anc-withstrong-lead-south-african-vote/oTiPA3A9fZ9dHLcYsEXNeO/story.html (accessed 09 10, 2014).

Polokwane Municipality. Framework Plan for Strategic Development Area 1. Plan, Land Use Management and Spatial Planning, Polokwane Municipality, Polokwane: Polokwane Municipality, 2007.

Press, City. City Press. December 5, 2011. http://www.citypress.co.za/news/five-limpopo-departmentsunder-administration-20111205/ (accessed March 12, 2014).

Prudman, S, and N Heynen. "Introduction: Uneven Development 25 Years On: Space, Nature and the Geographies of Capitalism." New Political Economy 16, no. 2 (2011): 223-232.

Rakodi, Carole. "A capital assets framework for analysing household livelihood strategies: implications for policy." Development policy review 17, no. 3 (1999): 315-342.

Rakodi, Carole. "A livelihoods approach: conceptual issues and definitions." In Urban Livelihoods: A people-centered approach to reducing poverty, by Carole Rakodi with Tony Lloyd-Jones, 3-22. New York, NY: Earthscan, 2002.

Ramutsindela, Maano. "Down the post-colonial road: reconstructing the post-apartheid state in South Africa." Political Geography 20, no. 1 (2001): 57-84.

Reid, Robin S, et al. "Land-use and land-cover dynamics in ersponse to changes in climatic, biological and socio-political forces: the case of southwestern Ethiopia." Landscape Ecology 15 (2000): 339355.

Republic of South Africa. "Republic of South Africa - Documents." Statues of the Republic of South Africa - Constitutional Law. RSA. 12 18, 1996. http://www.gov.za/documents/constitution/1996/a10896.pdf (accessed 09 10, 2014).

Rogerson, Christian M. "The impact of the South African government's SMME programmes: a ten year review (1994-2003)." Development Southern Africa 21, no. 5 (2004): 765-784.

Rogerson, Christian M. "Urban poverty and the informal economy in South Africa's economic heartland." Environment and Urbanization (Sage Publications) 8, no. 1 (1996): 167-179.

Sadiki, Patrick, and Maano Ramutsindela. "Peri-urban transformation in South Africa: Experience from Limpopo Province." GeoJournal 57 (2002): 75-81. 
Schneider, Geoffrey E. "Neoliberalism and Economic Justice in South Africa: Revisiting the Debate on Economic Apartheid." Review of Social Economy 1, no. 1 (2003): 23-50.

Schoorl, J, and A Veldcamp. "Linking land use and landscape process modeling: a case study for the Alora Region (South Spain)." Agriculture, Ecosystems and Environment 85 (2001): 281-292.

Scoones, Ian. "Livelihoods perspectives and rural development." The Journal of Peasant Studies (Taylor \& Francis) 36, no. 1 (May 2009): 171-196.

Scoones, Ian. "Sustainable Rural Livelihoods: A Framework for Analysis." IDS Working Paper 72 (1998): 122.

Seto, Karen C., et al. "Urban land teleconnections and sustainability." Edited by Susan Hanson. PNAS 109, no. 20 (2012): 7687-7692.

Simon, David. "Urban Environments: Issues on the Peri-Urban Fringe." Annual Review of Environment and Resources 33 (2008): 167-185.

Simon, David, Donald Thompson, and Duncan McGregor. "Contemporary Perspectives on the Peri-Urban Zones of Cities in Developing Countires." In The Peri-Urban Interface: Approaches to Sustainable Natural and Human Resource Use, by Duncan McGregor, David Simon and Donald Thompson, 112. Sterling, VA: Earthscan, 2006.

Simon, David, Duncan McGregor, and Kwasi Nsiah-Gyabaah. "The changing rural-urban interface of African cities: definitional issues and an application to Kumasi, Ghana." Environment and Urbanization 16 (2004): 235-247.

Smith, Jennifer. "Deproletarianization of the Peri-Urban Interface: transforming labor relations in Polokwane, South Africa." Human Geography 7, no. 3 (10 2014): 44-59.

Smith, Neil. Uneven Development: Nature, Capital and the Production of Space. 3rd. Athens, GA: University of Georgia Press, 2008.

Smith, Neil, and Phil O'Keefe. "Geography, Marx and the Concept of Nature." Antipode 12, no. 2 (1980): 30-39.

Statistics South Africa. Census 2011 Municipal Report - Limpopo Province. Summary, Census Bureau, Republic of South Africa, Pretoria: StatsSA, 2012.

Statistics South Africa. Provinces at a Glance. Summary, Census Bureau, Republic of South Africa, Pretoria: StatsSA, 2012.

Thompson, Leonard M. History of South Africa. New Haven, CT: Yale University Press, 2001.

Thornton, Alexander. "Beyond the metropolis: small town case studies of urban and peri-urban agriculture in South Africa." Urban Forum (Springer Netherlands) 19, no. 3 (2008): 243-262. 
Turner, Billie L, Eric F Lambin, and Anette Reenberg. "The emergence of land change science for global environmental change and sustainability." Proceedings of the National Academy of Sciences 104, no. 52 (2007): 20666-20671.

Turner, Matthew D. "Merging Local and Regional Analyses of Land-Use Change: The Case of Livestock in the Sahel." Annals of the Association of American Geographers 89, no. 2 (1999): 191-219.

Valentine, Gill. "Tell me about...: using interviews as a research methodology." In Methods in Human Geography: a guide for students doing a research project, edited by Robin Flowerdew and David Martin, 110-126. Essex: Addison Wesley Longman, 1997.

Wainwright, Joel. "Uneven Development: From the Gundrisse to Capital." Antipode 40, no. 5 (2008): 879-897.

Walker, Rob. "On the trail of South Africa's missing textbooks." BBC News Africa. October 3, 2012.

Walker, Robert. "Mapping Process to Pattern in the Landscape change of the Amazonian Frontier." Annals of the Association of American Geographers 93, no. 2 (2003): 376-398.

Walker, Robert, and William Solecki. "Theorizing Land-Cover and Land-Use Change: The Case of the Florida Everglades and Its Degradation." Annals of the Association of American Geographers 94, no. 2 (2004): 311-328.

World Bank. World Development Indicators: World Development Indicators 2011. Report, World Bank, Herndon, VA: World Bank Publications, 2011, 466. 